\title{
TSUNAMI INUNDATION MAPS FOR THE COMMUNITIES OF CHIGNIK AND CHIGNIK LAGOON, ALASKA
}

\author{
D.J. Nicolsky, E.N. Suleimani, and R.D. Koehler
}

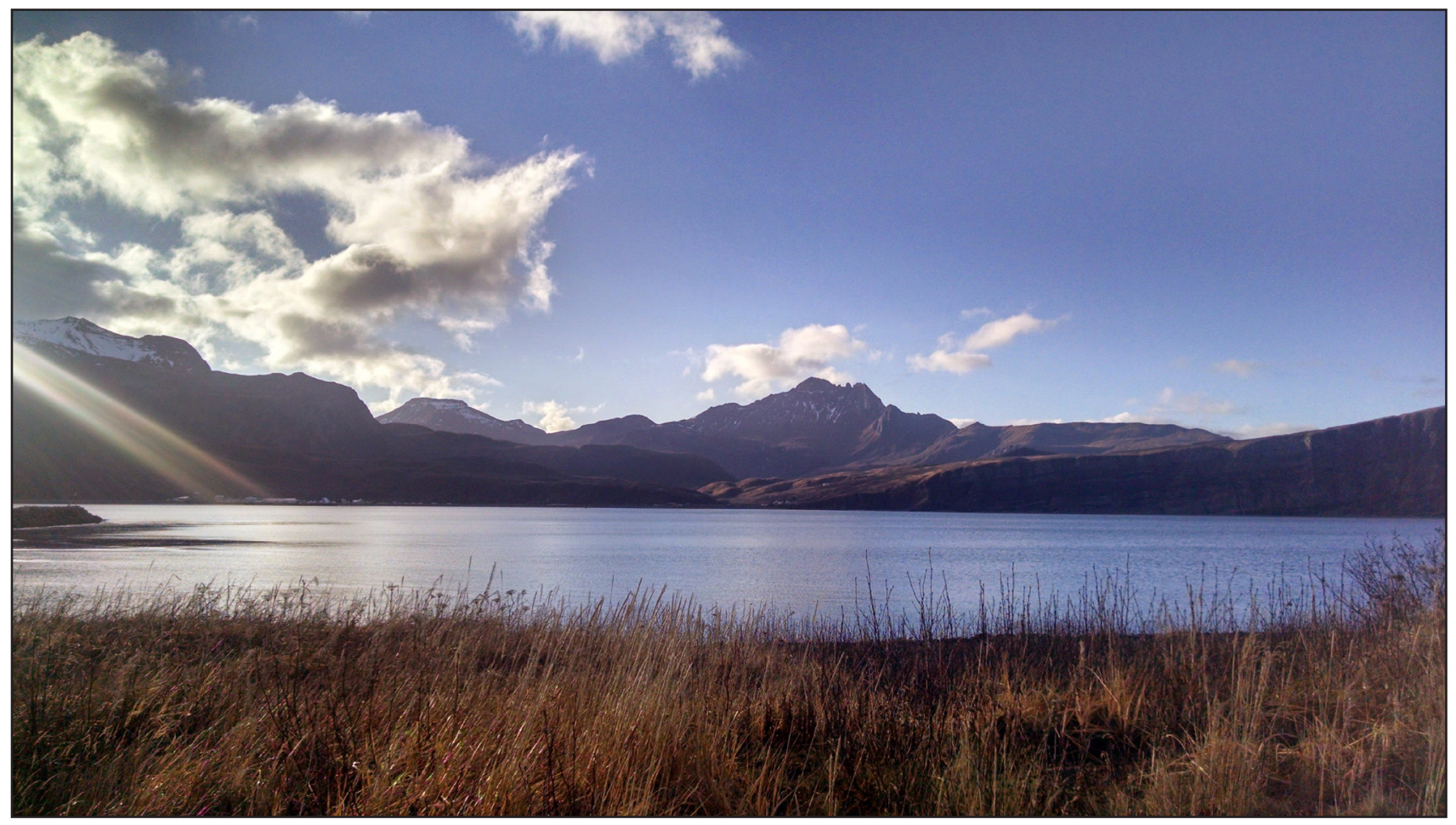

View to the southwest of Anchorage Bay; the community of Chignik is at its head. Photo by Amy Macpherson.
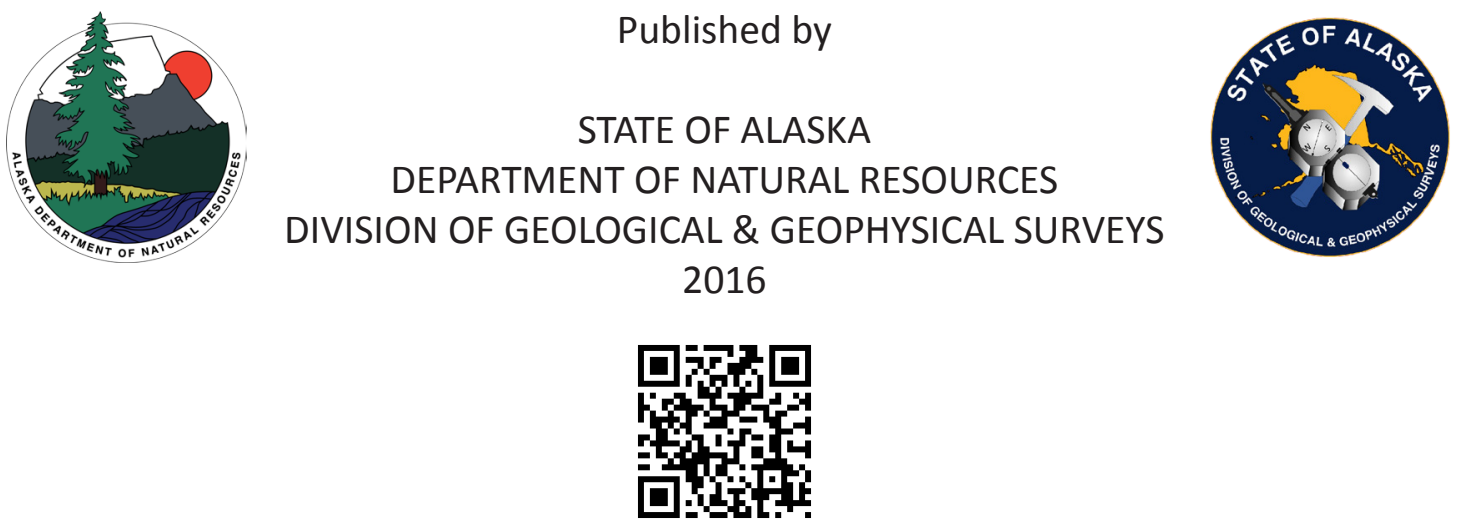



\section{TSUNAMI INUNDATION MAP FOR THE COMMUNITIES OF CHIGNIK AND CHIGNIK LAGOON, ALASKA}

D.J. Nicolsky, E.N. Suleimani, and R.D. Koehler

Report of Investigations 2016-8

State of Alaska

Department of Natural Resources

Division of Geological \& Geophysical Surveys 



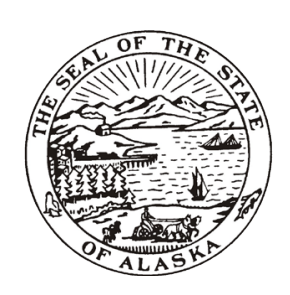

\title{
STATE OF ALASKA
}

Bill Walker, Governor

\section{DEPARTMENT OF NATURAL RESOURCES \\ Andy Mack, Commissioner}

\section{DIVISION OF GEOLOGICAL \& GEOPHYSICAL SURVEYS}

\author{
Steve Masterman, State Geologist and Director
}

Publications produced by the Division of Geological \& Geophysical Surveys (DGGS) are available for free download from the DGGS website (dggs.alaska.gov). Publications on hard-copy or digital media can be examined or purchased in the Fairbanks office:

\section{Alaska Division of Geological \& Geophysical Surveys 3354 College Rd., Fairbanks, Alaska 99709-3707 \\ Phone: (907) 451-5010 Fax (907) 451-5050 \\ dggspubs@alaska.gov \\ dggs.alaska.gov}

Alaska State Library

State Office Building, 8th Floor 333 Willoughby Avenue

Juneau, Alaska 99811-0571
Alaska Resource Library \& Information Services (ARLIS)

3150 C Street, Suite 100

Anchorage, Alaska 99503-3982 


\section{CONTENTS}

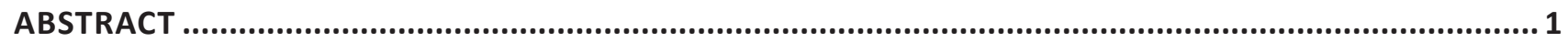

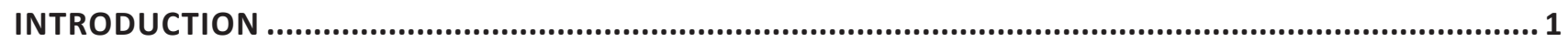

PROJECT BACKGROUND: REGIONAL AND HISTORICAL CONTEXT ............................................... 1

Setting

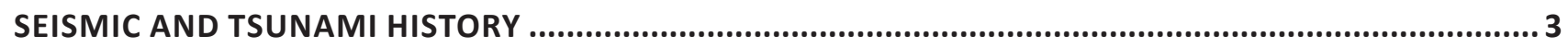

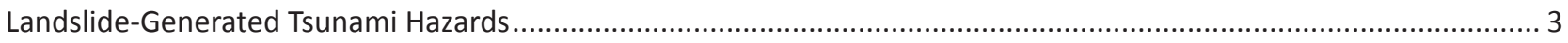

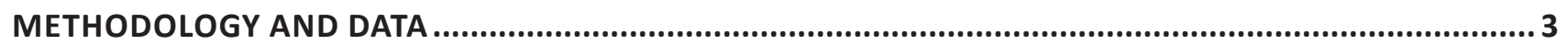

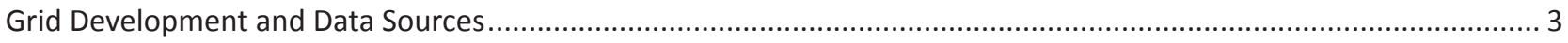

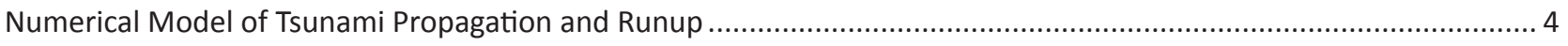

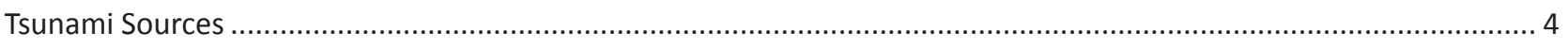

Sensitivity Study

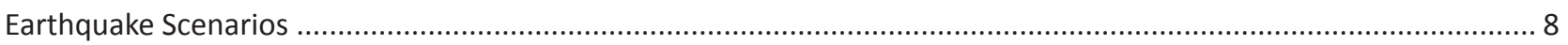

Scenario 1: $\mathrm{M}_{\mathrm{W}} 8.9$ earthquake along the Alaska Peninsula, $30 \mathrm{~km}(18.6 \mathrm{mi})$ depth........................................... 8

Scenario 2: $\mathrm{M}_{\mathrm{W}} 8.9$ earthquake along the Alaska Peninsula, $25 \mathrm{~km}(15.5 \mathrm{mi})$ depth............................................ 8

Scenario 3: $M_{W} 8.9$ earthquake along the Alaska Peninsula, $35 \mathrm{~km}(21.7 \mathrm{mi})$ depth........................................... 17

Scenario 4: $M_{W} 9.0$ earthquake along the Alaska Peninsula, $10 \mathrm{~km}(6.2 \mathrm{mi})$ depth............................................ 17

Scenario 5: $\mathrm{M}_{\mathrm{W}} 9.0$ earthquake along the Alaska Peninsula, $13 \mathrm{~km}(8.1 \mathrm{mi})$ depth.............................................. 17

Scenario 6: $M_{W} 9.0$ earthquake along the Alaska Peninsula, 17 km (10.6 mi) depth........................................... 17

Scenario 7: $M_{W} 9.0$ earthquake according to the SAFRR project ...................................................................... 17

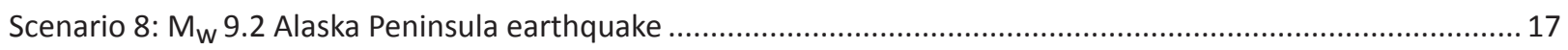

Scenario 9: $M_{W} 9.25$ Alaska Peninsula earthquake .................................................................................... 17

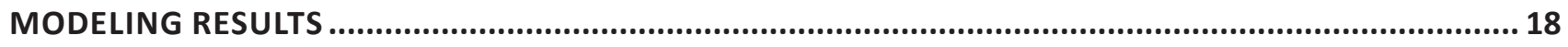

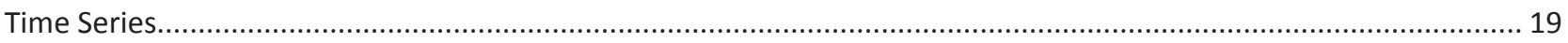

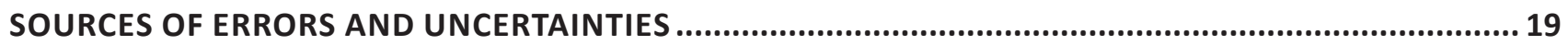

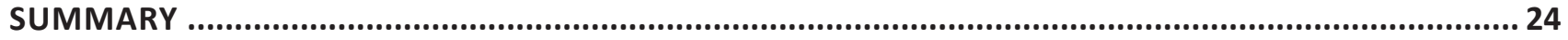

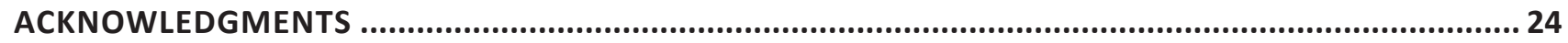

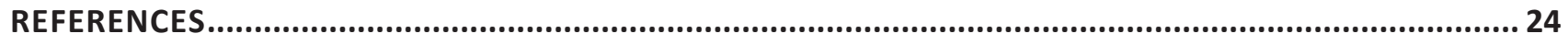

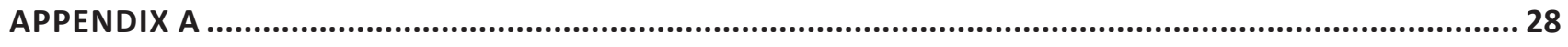

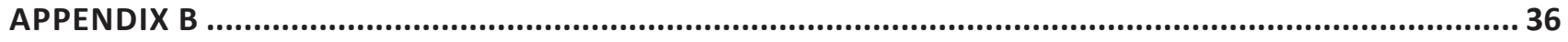




\section{FIGURES}

1. Map of south-central Alaska and the Alaska Peninsula, showing the locations of the Chignik and Chignik Lagoon communities, major faults, and the rupture zones of the 1938, 1946, $1948,1957,1964,1965,1986$, and 1996 Aleutian megathrust earthquakes .......................................... 2

2. Map of the Chignik area along the southern coast of the Alaska Peninsula ................................................ 2

3. Nesting of the Levels 2,3 , and 4 bathymetry/topography grids for numerical modeling of tsunami propagation and runup in the Chignik area communities ........................................................ 5

4. Locations of RTK (real-time kinematic) GPS measurements in Chignik and Chignik Lagoon.......................... 6

5. Observed water-level dynamics and fitted GPS measurements at Chignik and Chignik Lagoon.................... 7

6. Assumed slip distribution along the plate interface for cases $A-D$, modeling a $M_{W}$ 7.1-7.2

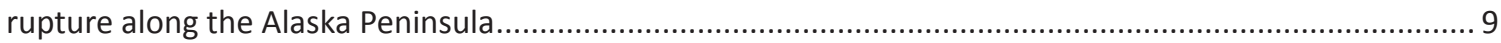

7. Computed vertical ground-surface deformation related to cases $A-D$ shown in figure 6 ......................... 10

8. Modeled water-level dynamics in Anchorage Bay offshore of Chignik for the ground-surface

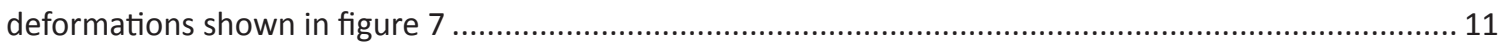

9. Proposed slip distribution along the plate interface for all scenarios .................................................... 12

10. Computed vertical ground-surface deformation related to the proposed slip distributions

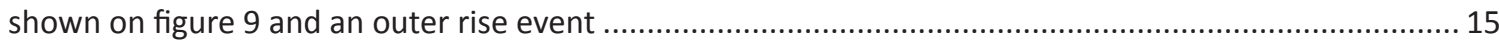

11. Modeled potential inundation in Chignik and Chignik Lagoon by tectonic waves for all scenarios ............. 20

12. Modeled time series of water level in Anchorage Bay for scenarios 1, 2, and 3; scenarios 4, 5, and 6; scenarios 7, 8, and 9; and scenarios 10 and 11

13. Modeled time series of water level in Chignik Lagoon for scenarios 1, 2, and 3; scenarios 4, 5, and 6; scenarios 7, 8, and 9; and scenarios 10 and 11

\section{TABLES}

1. Nested grids used to compute propagation of tsunami waves generated in the Pacific Ocean to the city of Chignik and village of Chignik Lagoon

2. All hypothetical scenarios used to model tsunami runup in the Chignik area ............................................ 11

3. Fault parameters for the hypothetical tensional $\mathrm{M}_{\mathrm{W}} 8.6$ outer-rise earthquake ...................................... 18

\section{APPENDICES}

\section{Appendix A Figures}

A-1. Locations of time series points in Anchorage Bay and the city of Chignik ............................................... 28

A-2. Time series of water level and velocity at selected locations in Anchorage Bay for scenarios $1,5,7$, and 9

\section{Appendix A Tables}

A-1. Longitude and latitude locations of the time series points in Chignik

\section{Appendix B Figures}

B-1. Locations of time series points in Chignik Lagoon and the village of Chignik Lagoon ............................... 36

B-2. Time series of water level and velocity at selected locations in Chignik Lagoon for scenarios $1,5,7$, and 9

\section{Appendix B Tables}

B-1. Longitude and latitude locations of the time series points in Chignik Lagoon

\section{SHEETS}

1. Maximum estimated tsunami inundation, Chignik Bay, Alaska

2. Maximum estimated tsunami inundation, Chignik Lagoon, Alaska 



\title{
TSUNAMI INUNDATION MAP FOR THE COMMUNITIES OF CHIGNIK AND CHIGNIK LAGOON, ALASKA
}

\author{
D.J. Nicolsky ${ }^{1}$, E.N. Suleimani ${ }^{1}$, and R.D. Koehler ${ }^{2}$
}

\begin{abstract}
Potential tsunami hazard for the Alaska Peninsula communities of Chignik and Chignik Lagoon is evaluated by numerically modeling the extent of inundation from tsunami waves generated by hypothetical earthquake sources. Worst-case hypothetical scenarios are defined by analyzing results of a sensitivity study of the tsunami dynamics related to various slip distributions along the Alaska-Aleutian megathrust. The worst-case scenarios for Chignik area communities are thought to be thrust earthquakes along the Alaska Peninsula with their greatest slip at 5-35 km (3.1-22 mi) depth. We also consider Tohoku-type ruptures and an outer-rise rupture along the Alaska Peninsula. The maximum predicted

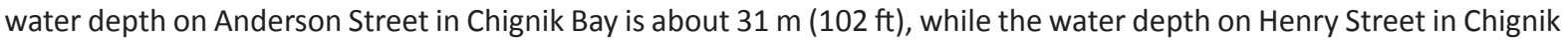
Lagoon is about $11 \mathrm{~m}$ (36ft). Maximum current velocity in the ocean could exceed $9 \mathrm{~m} / \mathrm{s}$ (17 kt) and significant wave action could continue for at least 8 hours after the earthquake. Results presented here are intended to provide guidance to local emergency management agencies in tsunami inundation assessment, evacuation planning, and public education to mitigate future tsunami hazards.
\end{abstract}

\section{INTRODUCTION}

Subduction of the Pacific plate under the North American plate has resulted in numerous great earthquakes and has the highest potential to generate tsunamis in Alaska (Dunbar and Weaver, 2008). Nearly the entire Aleutian megathrust has ruptured in the 20th century, including great $(M>8)$ earthquakes in 1938, 1946, 1957, 1964, and 1965 (Carver and Plafker, 2008, and references therein) (fig. 1). Additionally, several M 7.9 events have ruptured the western end of the subduction zone, including events in 1986, 1996, and 2014 (Boyd and Nabelek, 1988; U.S. Geological Survey National Earthquake Information Center, 2015). The most recent earthquakes that triggered great tsunamis in Chignik Bay occurred on April 1, 1946, and March 28, 1964. The tsunami waves resulting from these events were as high as $1.5 \mathrm{~m}(5 \mathrm{ft})$ and $3.0 \mathrm{~m}$ (10 ft), respectively (Lander, 1996). Locations of the 1946 and 1964 events relative to the Chignik area communities are shown in figure 1.

The following account of the tsunami waves at Chignik and Chignik Lagoon is taken from Lander (1996) unless otherwise noted. Subsequent to the 1946 earthquake a tsunami made its way to Chignik as a series of waves that resembled 1.5-m-high (5-ft-high) tides appearing every hour; there are no historical records of the 1946 tsunami in the village of Chignik Lagoon. During the 1964 event, the first wave arrived at Chignik about 2 hours after the main shock and the tsunami wave train had 12 distinct $3 \mathrm{~m}(10 \mathrm{ft})$ waves. In Chignik Lagoon the first wave arrived 3 hours after the earthquake and consecutive waves were only $0.9 \mathrm{~m}(3 \mathrm{ft})$ high. Nevertheless, about 6-7 hours after the earthquake, a 3-m-high (10-ft-high) wave entered Chignik Lagoon during low tide and reached $0.3-0.6 \mathrm{~m}(1-2 \mathrm{ft})$ above the high water level near the village (Cloud and Scott, 1969). Despite the relatively small size of these historical tsunamis, the potential future occurrence of earthquakes and tsunamis necessitates the development of inundation and tsunami evacuation maps for use in tsunami risk mitigation. In this report, we provide an analysis of the tsunami hazard and develop tsunami inundation maps for the city of Chignik and village of Chignik Lagoon.

The methodologies used to develop tsunami inundation maps are described in detail in multiple publications and are not reviewed in this report. Refer to Suleimani and others (2010, 2013, 2015) and Nicolsky and others (2011a, 2013, $2014,2015)$ for a full description of the procedure.

\section{PROJECT BACKGROUND: REGIONAL AND HISTORICAL CONTEXT}

\section{SETTING}

The Chignik area is located on the Alaska Peninsula at about $56^{\circ} 18^{\prime} \mathrm{N}, 158^{\circ} 24^{\prime} \mathrm{W}$, approximately $750 \mathrm{~km}(465 \mathrm{mi})$ west of Anchorage and 2,600 km (1,615 mi) northwest of Seattle (fig. 1). A map of Chignik communities is shown in figure 2. The Kaniagmuit Eskimo village of Kalwak was originally located in Anchorage Bay, but during the Russian Period the village was destroyed (Department of Commerce, Community, and Economic Development [DCCED]/Division of Community and Regional Affairs [DCRA], 2015; Gulf of Alaska Coastal Communities Coalition, 2003). In the late 1880 s, a new fishing village named Chignik - meaning 'big wind' in Koniag (Sugpiaq) Aleut—was established. Two canneries were soon constructed and provided ample job opportunities. A post office was established in 1901 and some coal mining occurred between 1899 and 1915. In 2008, one of the canneries was consumed by fire, having a devastating effect on the city. Currently, a community center, clinic, school, and lodge and more than 60 other buildings exist in the city of Chignik.

\footnotetext{
${ }^{1}$ Geophysical Institute, University of Alaska, P.O. Box 757320, Fairbanks, Alaska 99775-7320; djnicolsky@alaska.edu

${ }^{2}$ Alaska Division of Geological \& Geophysical Surveys, 3354 College Road, Fairbanks, AK 99709-3707
} 


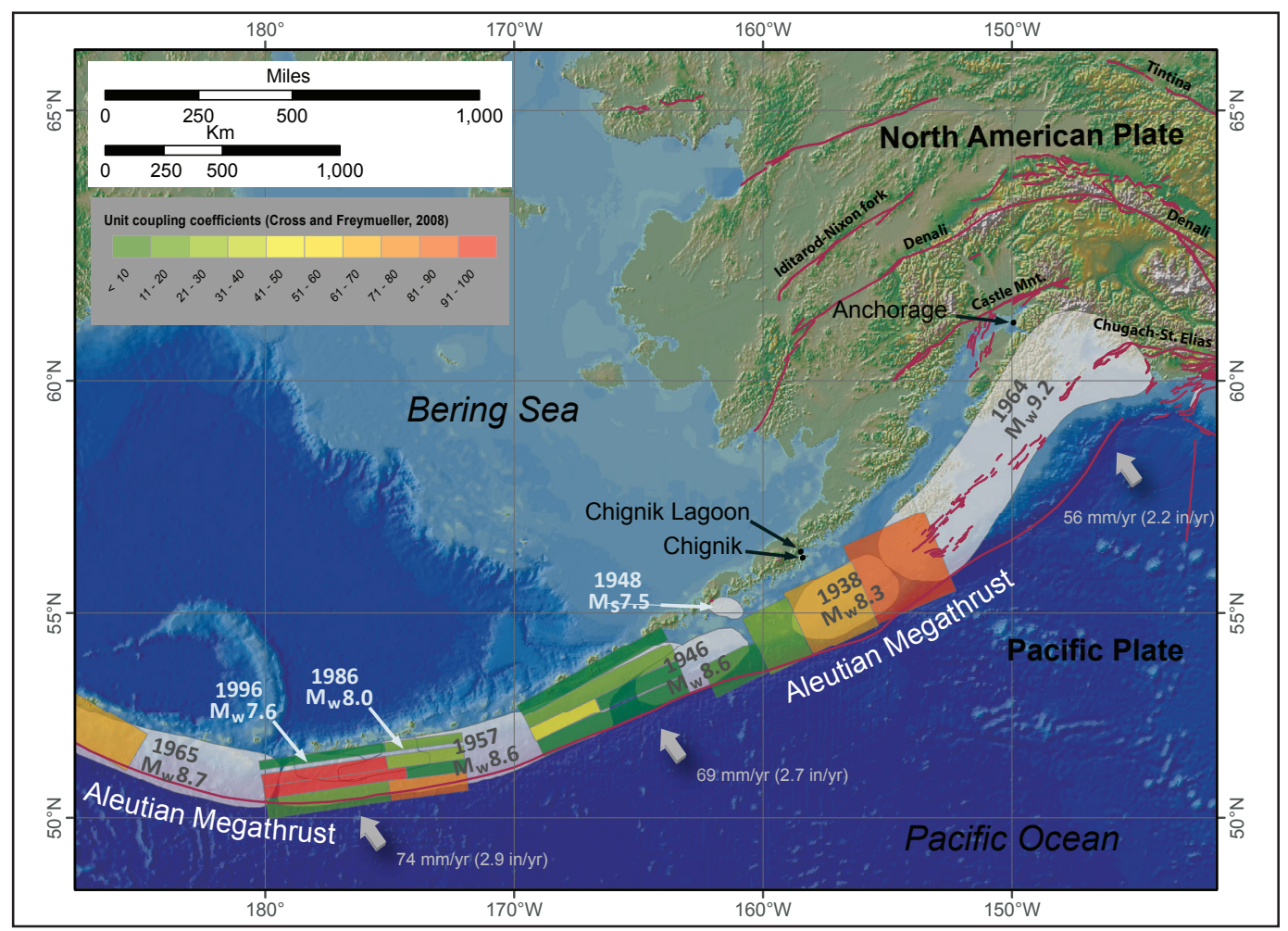

Figure 1. Map of south-central Alaska and the Alaska Peninsula, showing the locations of the Chignik and Chignik Lagoon communities, major faults (heavy red line), and the rupture zones of the 1938, 1946, 1948, 1957, 1964, 1965, 1986, and 1996 Aleutian megathrust earthquakes (light shaded areas). The coupling coefficient (Cross and Freymueller, 2008) along some segments of the megathrust is shown and indicated by color. A coupling coefficient of zero results when the plate interface is constantly slipping at the long-term relative plate velocity and indicates that no strain is building up to contribute to future great earthquakes. A coupling coefficient of 100 indicates no slip-that the plate interface is completely locked over that segment.

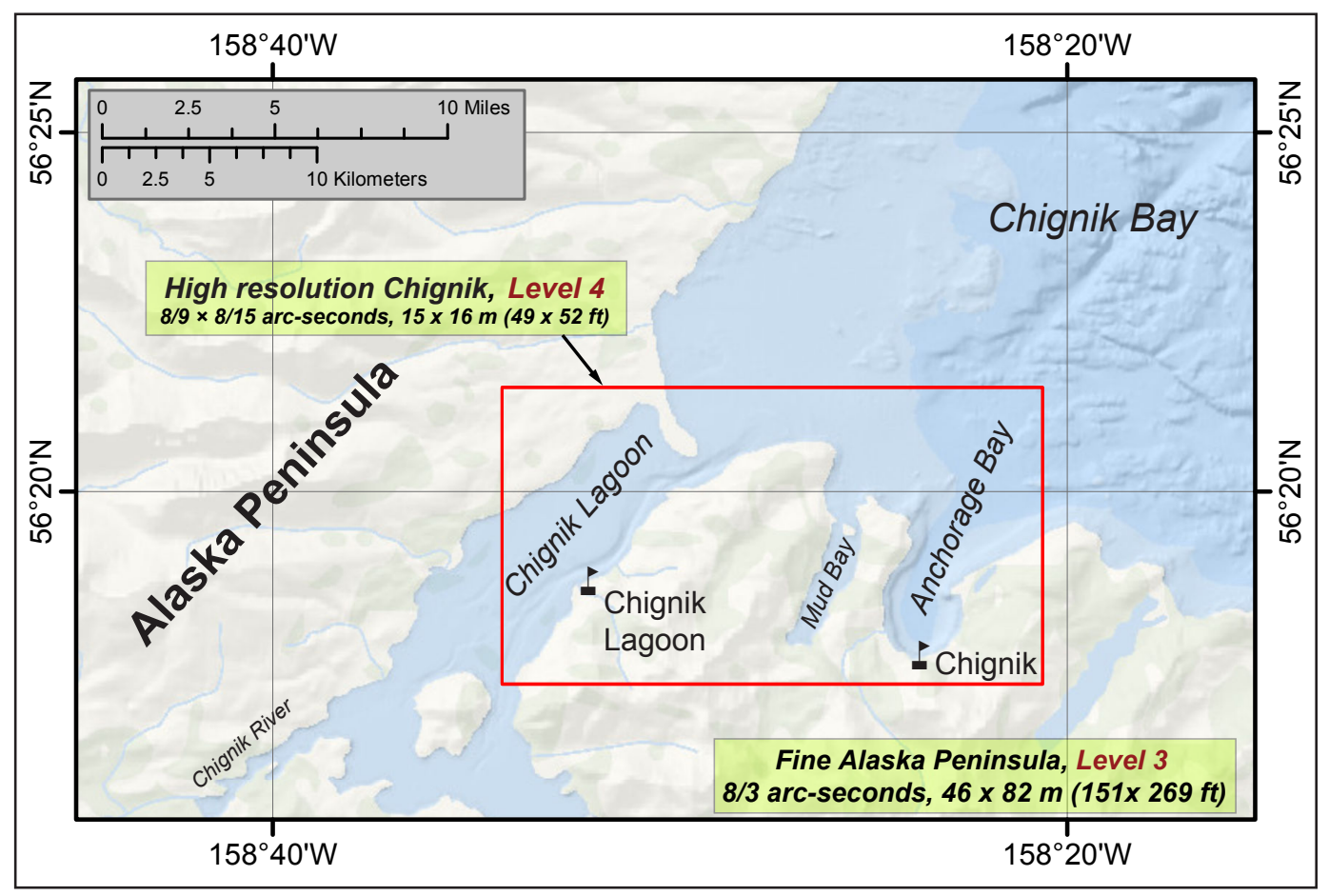

Figure 2. Map of the Chignik area along the southern coast of the Alaska Peninsula. Red rectangle marks the spatial extent of the high-resolution grid used to simulate tsunami runup around the city of Chignik and village of Chignik Lagoon. 
The village of Chignik Lagoon is $8 \mathrm{~km}(5 \mathrm{mi})$ from the city of Chignik. With no roads connecting the two communities, boats are the primary means of local transportation. As in Chignik, commercial salmon canning operations arrived at the village in the late 1880 s, establishing economic ties between the two communities that persist today. The 2010 U.S. Census recorded the population of Chignik as 91 and the population of Chignik Lagoon as 78. During the summer months populations grow considerably with the arrival of the seasonal work force.

Chignik and Chignik Lagoon communities are accessible by air, with regular flights from King Salmon, which land on two state-owned 2,600 ft and 1,810 ft gravel runways, respectively. The Alaska Marine Highway System provides regular ferry service to Chignik from Kodiak and Sand Point between May and October. However, there is no ferry service to Chignik Lagoon. A 110-slip small boat harbor and public docks are available in Chignik, while Chignik Lagoon has only a small boat harbor for a few boats and lacks any dock facilities. As in many other coastal communities, much of the economic activity and infrastructure is on or near the coasta potential tsunami inundation area. Refer to Community Development Plans (DCCED/DCRA, 2009; Chignik Lagoon Village Council, 2004) for a thorough review of the history, economy, and infrastructure of Chignik and Chignik Lagoon.

\section{SEISMIC AND TSUNAMI HISTORY}

Numerous earthquakes and tsunamis have likely affected the Chignik area communities (Nicolsky and others, in press, figs. 4 and 6). A description of these events, as well as the seismic and tsunami history for the nearby community of Sand Point, is provided in Nicolsky and others (in press); however, no reports or eyewitness accounts of these events in the Chignik area prior to 1946 are available. Given the close proximity of the Chignik area communities to the city of Sand Point, it is likely that all of these communities were affected similarly by earthquakes and tsunamis in the area.

\section{LANDSLIDE-GENERATED TSUNAMI HAZARDS}

The destructive effects of tsunamis generated by subaerial and underwater slope failures have been documented in south-central and southeastern Alaska, and destructive historical landslide tsunamis in Alaska and other parts of the world have occurred due to massive failures along continental slopes. The Storegga Slide (Bryn and others, 2005) and the Grand Banks Slide (Fine and others, 2005) generated catastrophic tsunamis along the coastlines of Norway and Canada, respectively. Similarly, Grilli and others (2013) propose that the 2011 Tohoku-Oki tsunami was generated by a combination of tectonic processes and submarine mass failures. Several authors have suggested a landslide component in the tsunami generation mechanism of the 1946 earthquake that impacted the Chignik area, for which the size of the tsunami was much larger than that estimated from the surface wave magnitude (Sykes, 1971; Johnson and Satake, 1997; Miller and others, 2014). Refer to Suleimani and others (2010; 2015) and Nicolsky and others (2013) for an overview of primary causes and triggers of tsunamigenic landslides in Alaska.
As in the tsunami modeling studies for Sand Point, Unalaska, and Akutan (Nikolski and others, 2015; in press), we do not model tsunamis generated by any mass failures due to insufficient data on the locations and volumes of these potential hazards. ${ }^{1}$

\section{METHODOLOGY AND DATA}

\section{GRID DEVELOPMENT AND DATA SOURCES}

We employ a series of nested computational grids to generate a detailed map of the potential tsunami inundation in the Chignik area. The coarsest grid, with 2-arc-minute (approximately $2 \mathrm{~km}[\sim 1.2 \mathrm{mi}]$ ) resolution, spans the central and northern Pacific Ocean. We use three intermediate grids between the coarsest- and highest-resolution grids (table 1). Note that the 2-arc-minute, 8- and 24-arc-second-resolution grids (Levels 0,1 , and 2) are the same as those used to model the potential tsunami inundation for Sand Point (Nicolsky and others, in press). The highest-resolution grid (Level 4) for the communities covers Anchorage Bay, Mud Bay, a part of Chignik Lagoon, and Chignik Bay. The lateral extent of the high-resolution grid is shown by a red rectangle in figure 2. The spatial resolution of the high-resolution grid cells, with about $15 \times 16 \mathrm{~m}(50 \times 54 \mathrm{ft})$ dimensions, satisfies National Oceanic and Atmospheric Administration (NOAA) minimum recommended requirements for computation of tsunami inundation (National Tsunami Hazard Mapping Program [NTHMP], 2010).

To develop high-resolution and 8/3-arc-second-resolution grids (Levels 3 and 4), shoreline, bathymetric, and topographic digital datasets were obtained from various agencies. Lateral extents and nesting of the Level 3 and Level 4 grids are displayed in figure 3. The bathymetric datasets include National Ocean Service (NOS) hydrographic surveys, NOAA Electronic Navigational Chart (ENC) soundings, a U.S. Army Corps of Engineers (USACE) harbor survey, multi-beam swath sonar surveys, and the National Centers for Environmental Information/National Oceanic and Atmospheric Administration (NCEI/NOAA) ETOPO1 Global Relief Model. The topographic dataset was obtained from NASA Space Shuttle Radar Topography Mission (SRTM) and Alaska Division of Community and Regional Affairs $(D C R A)$. All data were shifted to World Geodetic System 1984 (WGS 84) horizontal and Mean Higher High Water (MHHW) vertical datums. The data sources and methodology used to develop high-resolution and 8/3-arc-second digital elevation models (DEMs) are described in detail by Caldwell and others (2011) and Carignan and others (2014).

Accuracy of the high-resolution DEM around each of the communities was determined by the DCRA elevation datasets (DCCED/DCRA, 2002). The DCRA topography in both communities is based on the real-time kinematic (RTK) GPS surveys, which are referenced to the NOS Station 9458917 I TIDAL in Chignik (DCRA, Community Map Chignik, Sheet 1, 2002; DCRA, Community Map Chignik Lagoon,

\footnotetext{
${ }^{1}$ Guidelines and best practices for tsunami inundation modeling for evacuation planning state that the modeling should add value to mapping products (National Tsunami Hazard Mapping Program [NTHMP], 2010).
} 


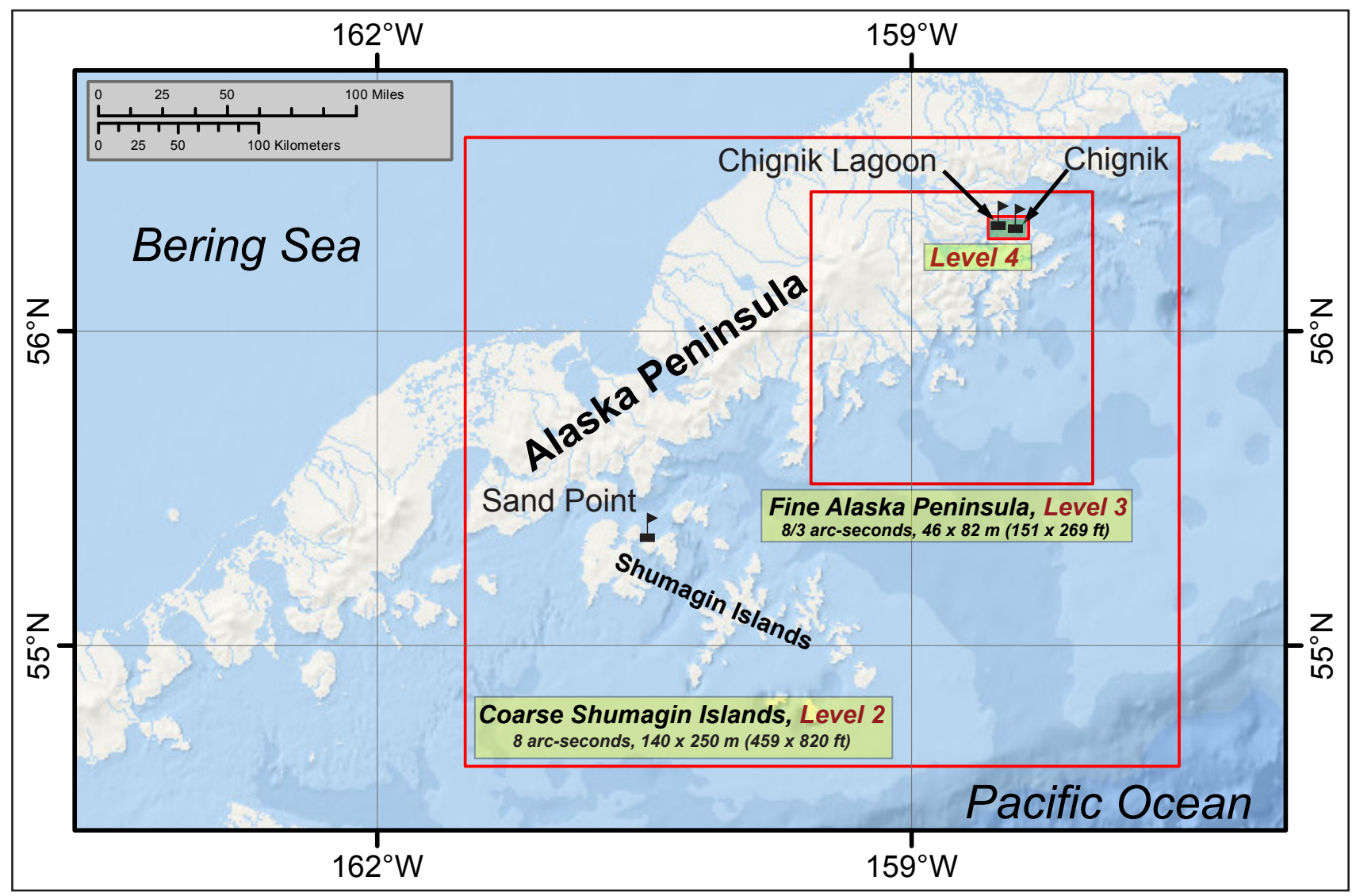

Figure 3. Nesting of the Levels 2, 3, and 4 bathymetry/topography grids for numerical modeling of tsunami propagation and runup in the Chignik area communities. The nesting of Levels 0 and 1 grids is shown in figure 7 of Nicolsky and others (in press). The location of each embedded grid is marked by a red rectangle. The green semi-transparent rectangle marks the area of the grid refinement.

Table 1. Nested grids used to compute propagation of tsunami waves generated in the Pacific Ocean to the city of Chignik and village of Chignik Lagoon. The high-resolution grid is used to compute the inundation. Note that the grid resolution in meters is not uniform: the first dimension is the longitudinal grid resolution and the second is the latitudinal resolution. Measurements also vary across each grid and are given for a reference location near Chignik Bay to illustrate relative grid fineness. Grids for Levels 0, 1, and 2 are the same as those used to model potential tsunami inundation in Sand Point in Nicolsky and others (in press).

\begin{tabular}{|l|c|c|c|c|}
\hline \multirow{2}{*}{\multicolumn{1}{|c|}{ Grid name }} & \multicolumn{2}{c|}{ Resolution } & \multirow{2}{*}{$\begin{array}{c}\text { East-West } \\
\text { boundaries }\end{array}$} & $\begin{array}{c}\text { North-South } \\
\text { boundaries }\end{array}$ \\
\cline { 2 - 3 } & $\begin{array}{c}\text { arc- } \\
\text { seconds }\end{array}$ & $\begin{array}{c}\text { meters (near } \\
\text { Chignik Bay }\end{array}$ & & \\
\hline Level 0, Northern Pacific & $120 \times 120$ & $\approx 1,850 \times 3,700$ & $120^{\circ} 00^{\prime} \mathrm{E}-100^{\circ} 00^{\prime} \mathrm{W}$ & $10^{\circ} 00^{\prime} \mathrm{N}-65^{\circ} 00^{\prime} \mathrm{N}$ \\
\hline Level 1, Eastern Aleutians & $24 \times 24$ & $\approx 430 \times 740$ & $171^{\circ} 58^{\prime} \mathrm{W}-157^{\circ} 02^{\prime} \mathrm{W}$ & $52^{\circ} 00^{\prime} \mathrm{N}-57^{\circ} 28^{\prime} \mathrm{N}$ \\
\hline $\begin{array}{l}\text { Level 2, Coarse-resolution Shumagin } \\
\text { Islands }\end{array}$ & $8 \times 8$ & $\approx 140 \times 250$ & $161^{\circ} 30^{\prime} \mathrm{W}-157^{\circ} 30^{\prime} \mathrm{W}$ & $54^{\circ} 36^{\prime} \mathrm{N}-56^{\circ} 36^{\prime} \mathrm{N}$ \\
\hline Level 3, Fine resolution Alaska Peninsula & $8 / 3 \times 8 / 3$ & $\approx 46 \times 82$ & $159^{\circ} 34^{\prime} \mathrm{W}-157^{\circ} 59^{\prime} \mathrm{W}$ & $55^{\circ} 31^{\prime} \mathrm{N}-56^{\circ} 26^{\prime} \mathrm{N}$ \\
\hline Level 4, High resolution Chignik & $8 / 9 \times 8 / 15$ & $\approx 15 \times 16$ & $158^{\circ} 34^{\prime} \mathrm{W}-158^{\circ} 20^{\prime} \mathrm{W}$ & $56^{\circ} 17^{\prime} \mathrm{N}-56^{\circ} 21^{\prime} \mathrm{N}$ \\
\hline
\end{tabular}


Sheet 1,2002). We note that the topography in the village of Chignik Lagoon had been adjusted to this NOS Station using some aerial photogrammetric methods (DCRA, Community Map Chignik Lagoon, 2002, Sheet 1) and hence might have some uncertainties. As in previous studies (Nicolsky and others, 2011a, 2014, 2015), we augmented the DCRA datasets with an additional RTK GPS survey along near-shore areas in Chignik and Chignik Lagoon. The survey in Chignik was conducted May 21-22, 2013; the survey in Chignik Lagoon was completed May 22-24, 2013. Locations of GPS measurements in the communities are shown in figures $4 \mathrm{~A}$ and $4 \mathrm{~B}$. GPS measurements were collected in the WGS84 horizontal datum. Following the methods of Nicolsky and others (2015; in press) we converted the collected GPS elevations to the MHHW datum by using the water-level dynamics measured during the survey at the NOAA tide gauge in Chignik. Tide measurements were provided by M.S. Christopher Popham, an oceanographer at the NTWC/NOAA (written commun., 2013). Comparisons of the GPS-estimated and NOAAobserved tide dynamics for Chignik and Chignik Lagoon are shown in figures $5 \mathrm{~A}$ and $5 \mathrm{~B}$, respectively. The converted GPS survey was provided to the NCEI, where the high-resolution DEM was developed.

Unfortunately, because we could not locate a NOAA tidal benchmark in either Chignik or Chignik Lagoon, we cannot check the accuracy of the survey conversion to the MHHW datum by estimating an elevation of the benchmark as described in Nicolsky and others (2015; in press). Previous studies (Nicolsky and others, 2015; in press) demonstrate that the conversion of the RTK GPS survey to the MHHW datum, using the observed tide dynamics, can yield sub-meter vertical accuracy for the converted elevations in the MHHW datum. The horizontal accuracy was determined by an initial positioning of the GPS base station, is thought to be about 3-5 m (10-16 ft) (Leica Geosystems AG, 2002).

\section{NUMERICAL MODEL OF TSUNAMI PROPAGATION AND RUNUP}

To estimate tsumani propagation and runup in the Chignik area, we use the same numerical model employed in other Alaska tsunami inundation studies (for example Suleimani and others, 2010, 2013, 2015, and Nicolsky and others, 2011a, 2013, 2014, 2015). All hypothetical tsunami simulations are conducted using the bathymetric/topographic data corresponding to the MHHW tide level in Chignik.

\section{TSUNAMI SOURCES}

It is generally thought that all of the great historic earthquakes along the Alaska-Aleutian subduction zone occurred on the megathrust - the contact surface between the subducting Pacific plate and the North American plate. Because of friction the two converging plates generally cohere to each other and thus shear stress builds up between these plates along the megathrust. The shear stress is typically released instantaneously during an earthquake and the seismic energy propagates through the ground, causing strong shaking. It is theorized that the shear stress is primarily acquired in the locked or coupled regions of the megathrust, where the friction is the greatest. Nicolsky and others (in press) provide a brief review of the regional seismotectonics of the
Alaska Peninsula with an emphasis on tsunami generation potential. Refer to Ryan and others (2012) and Kirby and others (2013) and references therein for a detailed discussion of the hypothetical tsunami sources along the eastern Alaska-Aleutian megathrust.

The locations of the locked and creeping zones along the Alaska-Aleutian megathrust between Kodiak Island and the Shumagin Islands has been modeled by Cross and Freymueller (2008) and Freymueller and others (2008). These studies employed geodetic observations of active deformation along the Alaska Peninsula to assess strain accumulation related to the earthquake cycle. In particular, Cross and Freymueller (2008) modeled GPS velocities from the Alaska Peninsula to find the extent of locking on the subduction interface. The interface between the Pacific and North America plates along the Alaska Peninsula and Shumagin Islands was divided into several rectangular planar segments (Cross and Freymueller, 2008, fig. 4). They estimated the amount of slip occurring on each segment; the results are reported in terms of a coupling coefficient for each plane. A coupling coefficient of zero results when the plate interface is constantly slipping at the long-term relative plate velocity and indicates that no strain is building up to contribute to future great earthquakes. A coupling coefficient of 100 indicates no slip - that the plate interface is completely locked over that segment. Regions with high coupling coefficients are termed 'locked zones.' A coupling coefficient between these values may mean that only a portion of the plate interface is locked, or it could mean that the entire interface creeps at a rate somewhat slower than the rate of plate motion. The coupling coefficient for each plane is marked by values shown in Cross and Freymueller (2008, fig. 4) and reproduced on figure 1 .

The modeling results by Cross and Freymueller (2008) reveal that the plate interface across the Chignik area is dominated by locking (coupling coefficient 70), and indicate that shear stress is accumulating on the interface between $5 \mathrm{~km}(3.1 \mathrm{mi})$ and $35 \mathrm{~km}(22 \mathrm{mi})$ depths. The estimated downdip extent of seismic coupling inferred from these earthquakes generally agrees with the analysis of seismicity by Tichelaar and Ruff (1993), who predicted the downdip limit of the locked region to be between 37 and $41 \mathrm{~km}$ (23-25 mi) depth.

Locating the updip limit of the locked zone is hindered by the lack of geodetic data close to the Aleutian trench, and is essentially unconstrained by the land-based geodetic data. Seafloor GPS/acoustic measurements would be required to determine the existence or non-existence of high coupling at shallow depth. Recent studies comparing the Alaska and Tohoku margins (Kirby and others, 2013) propose that a hypothetical rupture might propagate to shallow depths, similar to the $M_{W} 9.0$ Tohoku earthquake, based on several similarities between the two margins.

Similar to the tsunami analyses on Unalaska and Akutan Islands (Nicolsky and others, 2015), we conducted a sensitivity study specific to the city of Chignik and investigated waves arriving from a variety of idealized ruptures from different downdip locations in the locked region. The results of the sensitivity study are then applied to construct the maximum credible scenarios. 


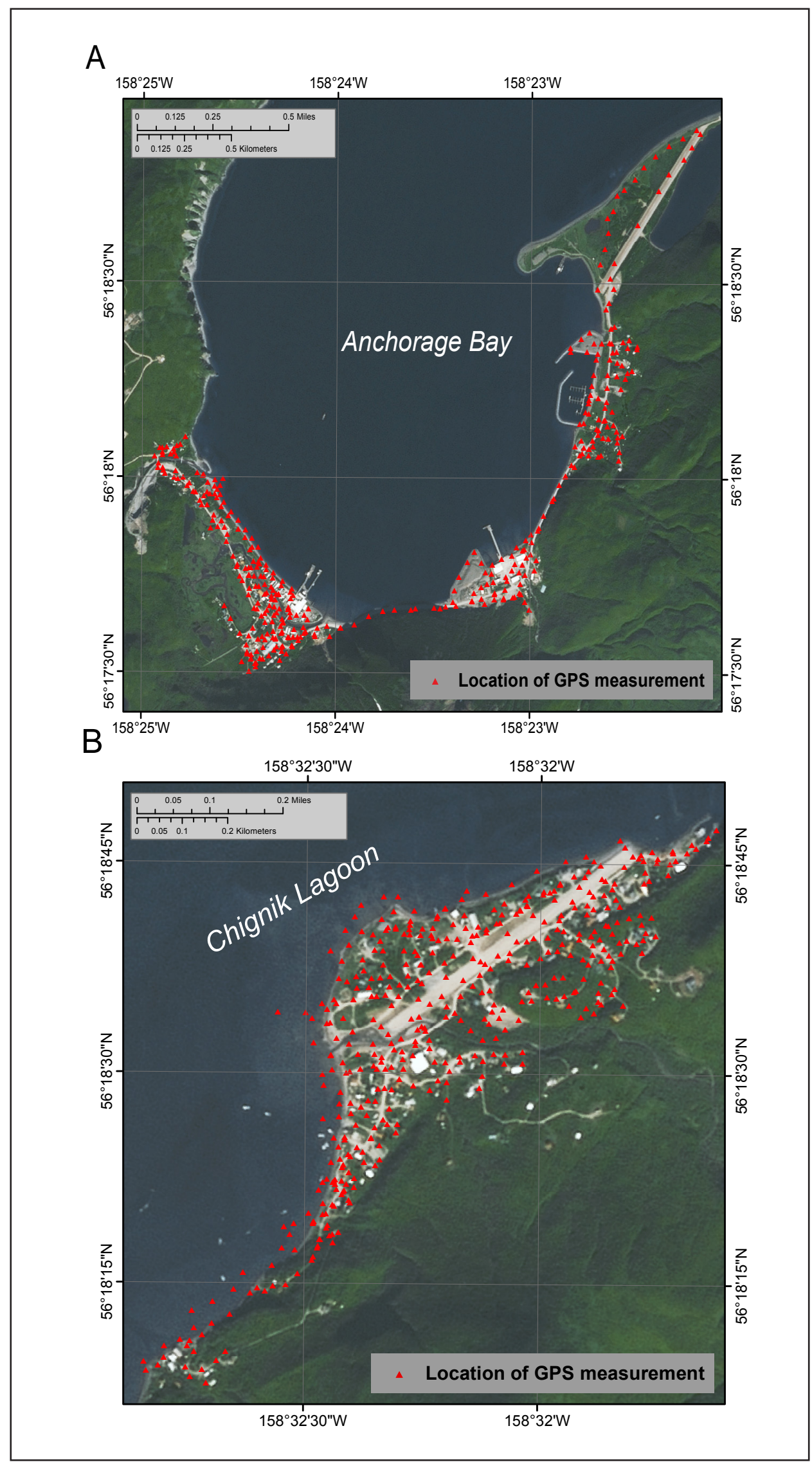

Figure 4. Locations of RTK (real-time kinematic) GPS measurements in (A) Chignik and (B) Chignik Lagoon. 


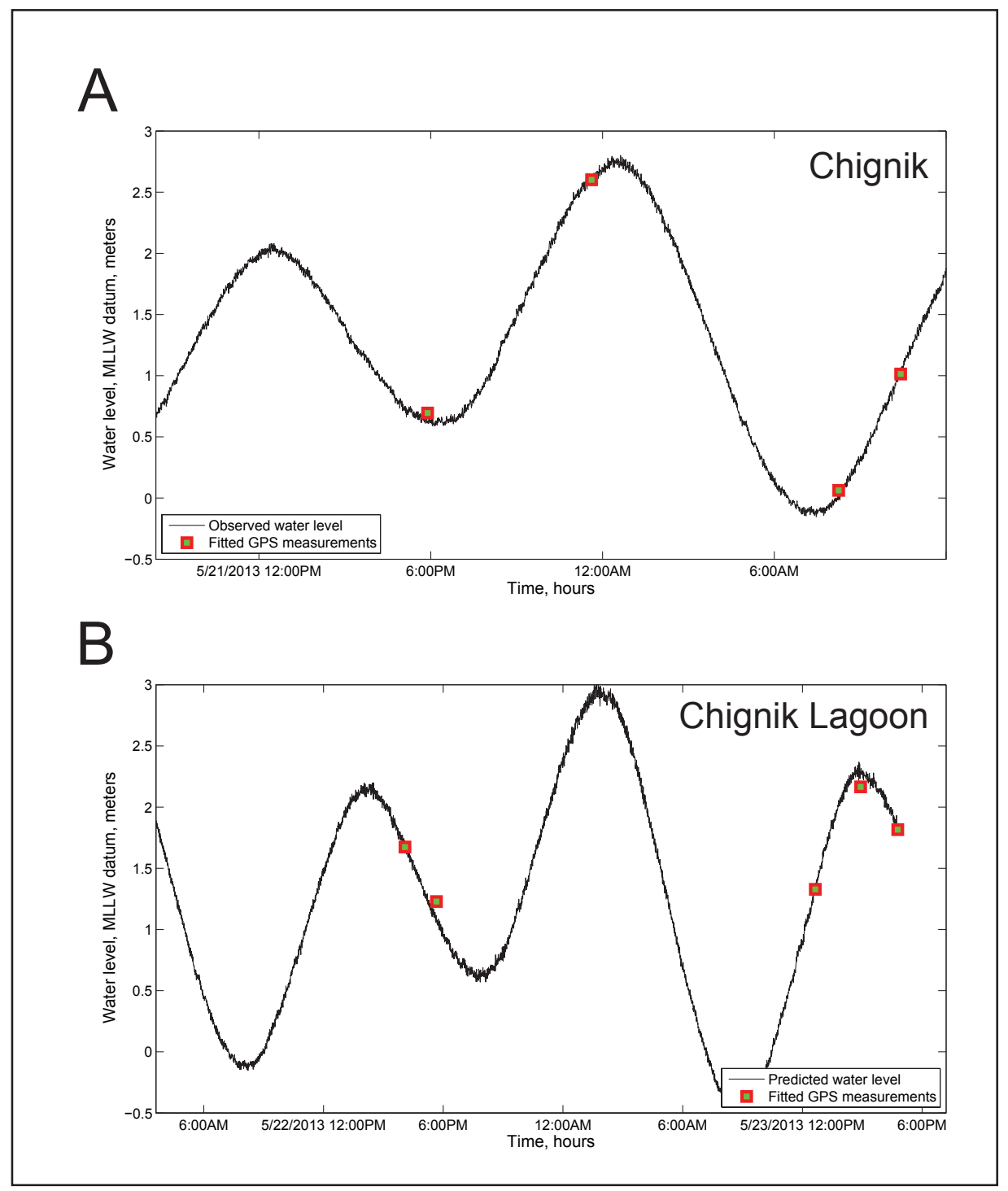

Figure 5. Observed water-level dynamics and fitted GPS measurements at (A) Chignik and (B) Chignik Lagoon. Water level is in the MHHW datum.

\section{SENSITIVITY STUDY}

To test the sensitivity of wave heights from ruptures originating at different downdip locations, we develop four hypothetical cases of the slip distribution (cases A-D) for $\mathrm{M}_{\mathrm{W}}$ 7.1-7.2 earthquakes that could occur in the partially locked segment of the megathrust across from the Chignik area (fig. 6 ). The relative slip distribution for all four cases is identical: uniform in the along-strike direction with tapering at the ends of the rupture, a symmetrical bell-type slip curve in the downdip direction. The maximum slip for each hypothetical rupture is assumed to be $5 \mathrm{~m}(16 \mathrm{ft})$. Between any two consecutive cases, the hypothetical rupture is offset by about $10 \mathrm{~km}(6.2 \mathrm{mi})$ in the downdip direction: Case A corresponds to a rupture at $40 \mathrm{~km}(25 \mathrm{mi})$ depth, Case B corresponds to a rupture at $30 \mathrm{~km}(18.6 \mathrm{mi})$ depth, and so on to Case D with at $10 \mathrm{~km}(6.2 \mathrm{mi})$ depth. The vertical deformation associated with each case is shown in figure 7. Blue shading indicates ground subsidence; red shading marks areas of uplift.
There are no known geologic or paleoseismologic records of land-level change in this area and thus there are no constraints to calibrate the modeled ground subsidence and uplift in the Chignik area. In this report, we assume that all cases considered are geologically plausible and realistically simulate the water dynamics near the waterfront in Chignik. The simulated water levels at the head of Anchorage Bay, offshore of Chignik, are shown in figure 8. The first maximum wave crests (marked by black arrows) arrive at Chignik in cases $\mathrm{A}, \mathrm{B}$, and $\mathrm{C}$ in the time window between 1 hour and 1 hour 40 minutes. Therefore, if adjacent downdip sections (corresponding to cases A and B, or to cases B and C) rupture simultaneously, the waves generated separately by each section may constructively interfere to produce a larger wave. The numerical experiments also reveal that a little more than 2 hours after the occurrence of the earthquake, other wave crests (marked by red arrows) associated with cases 
A

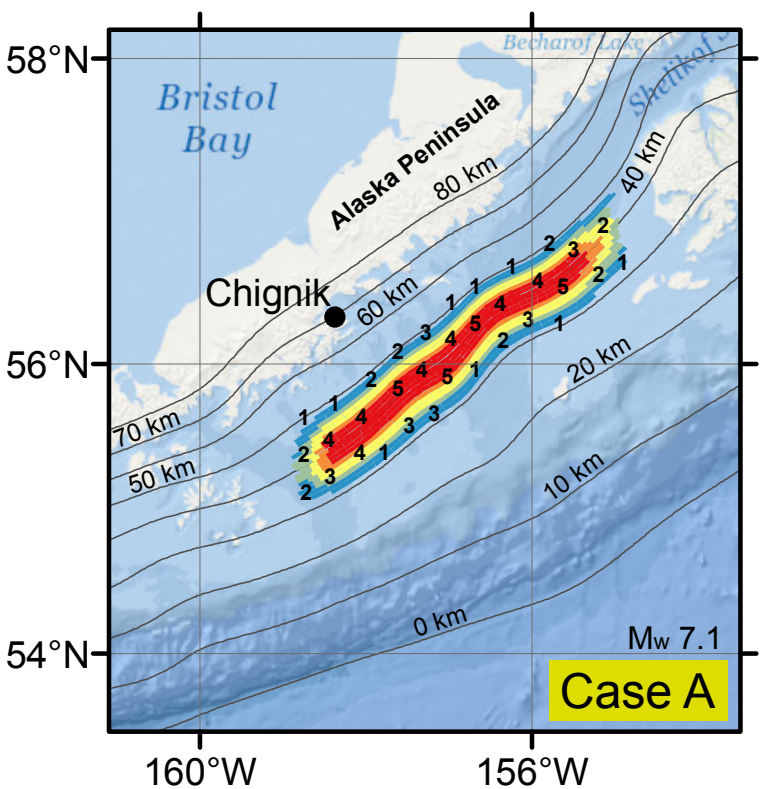

C

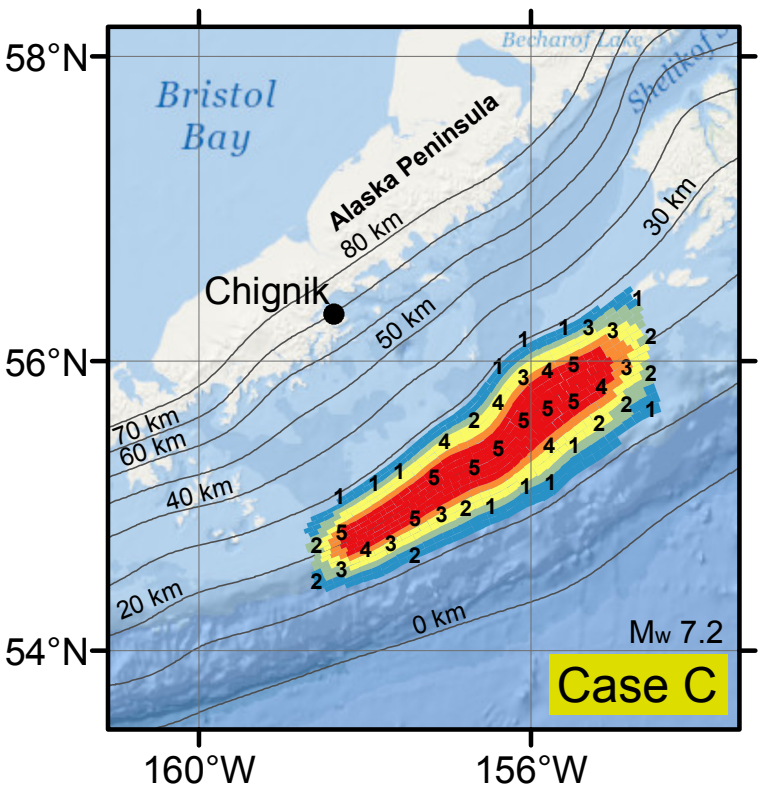

B

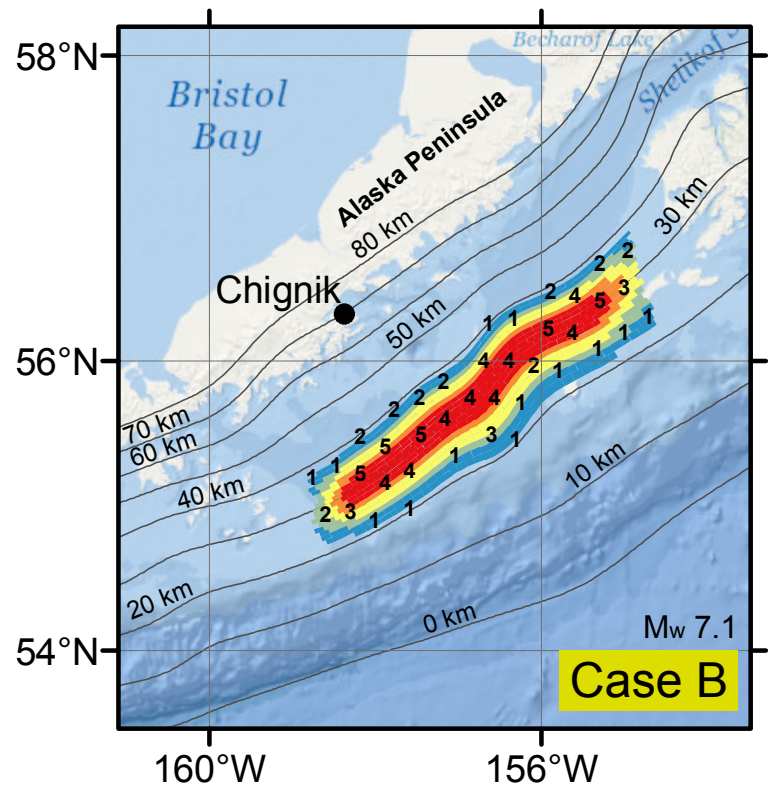

D

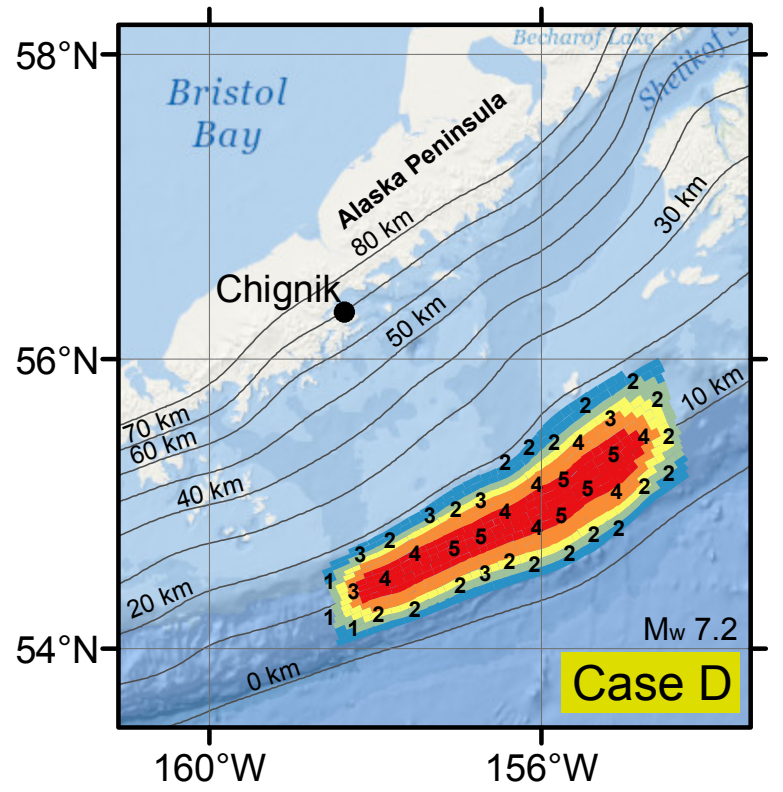

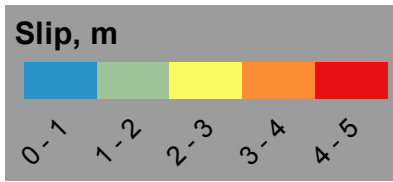

Figure 6. Assumed slip distribution along the plate interface for cases $A-D$, modeling a Mw 7.1-7.2 rupture along the Alaska Peninsula. The slip location varies in the downdip direction of the plate interface while preserving the same patch configuration. The value of slip, in meters, is shown by black numbers. Gray lines are depth contours of the subduction interface, in kilometers. Chignik is marked by a black circle. 
A

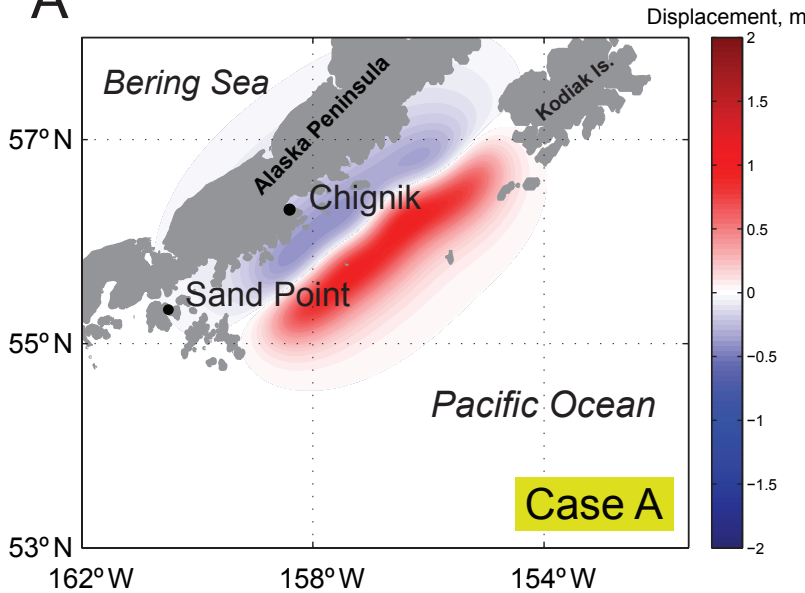

C

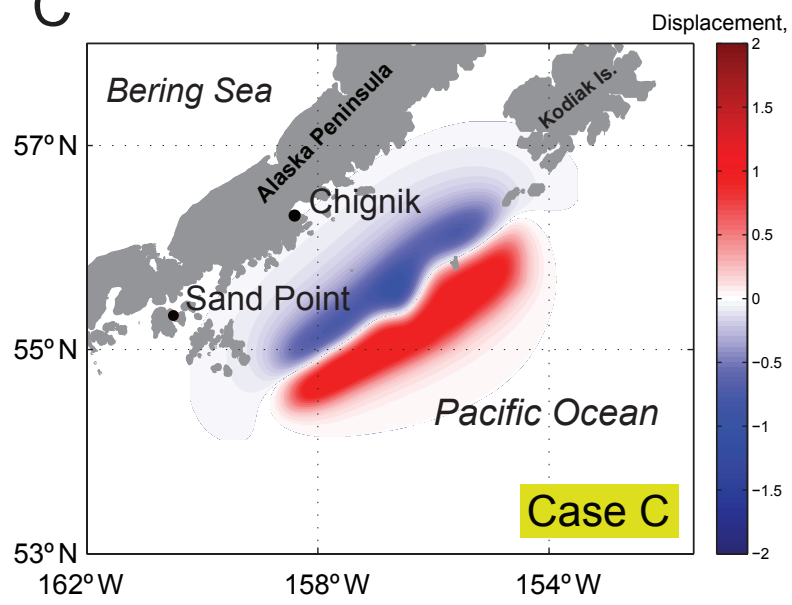

B

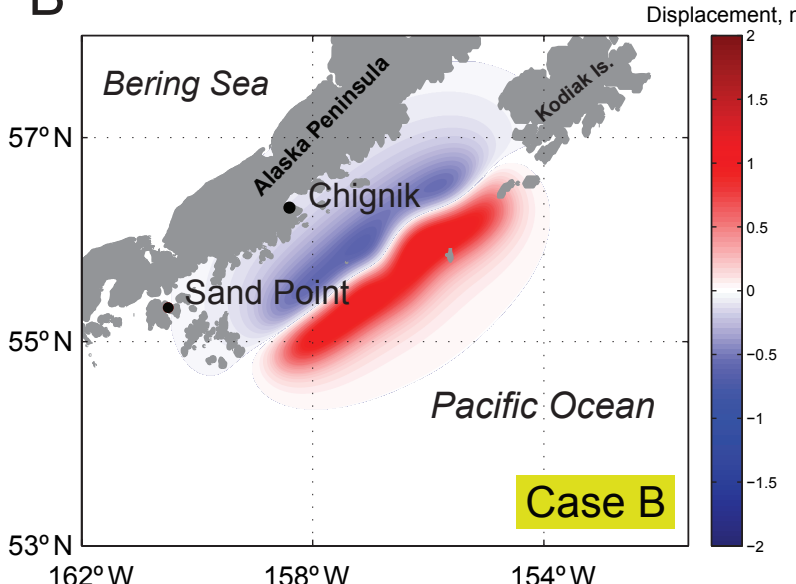

$\mathrm{D}$

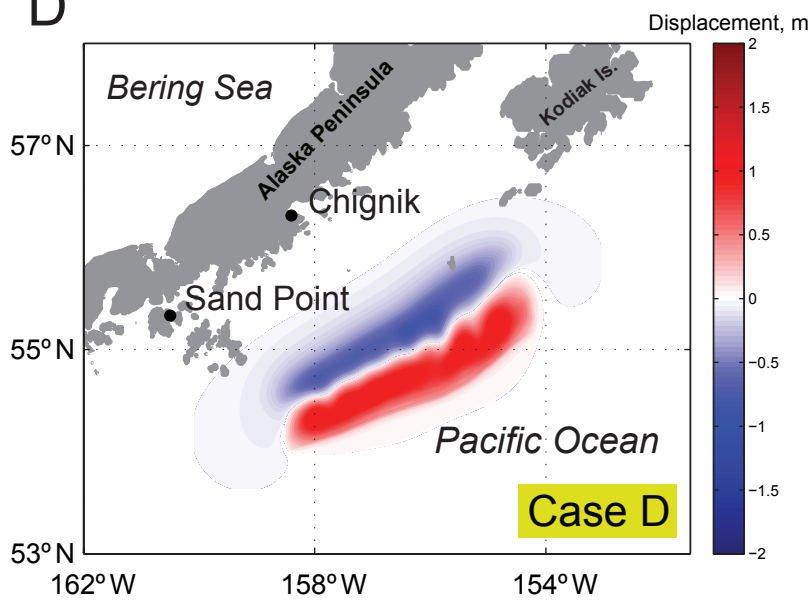

Figure 7. Computed vertical ground-surface deformation related to cases A-D shown in figure 6. Blue areas are associated with coseismic ground subsidence; areas of uplift are shown in red.

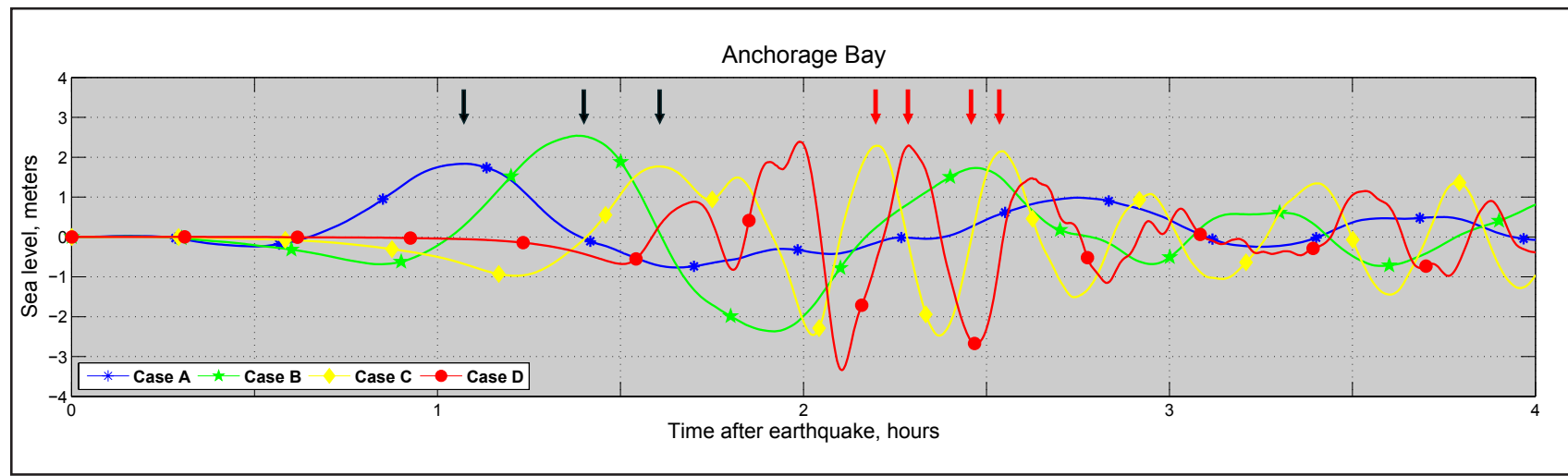

Figure 8. Modeled water-level dynamics in Anchorage Bay offshore of Chignikfor the ground-surface deformations shown in figure 7. Black vertical arrows mark waves that may contribute to the constructive interference associated with cases $A, B$, and $C$; red vertical arrows mark another group of waves that may contribute to constructive interference associated with cases $B, C$, and $D$. 
Table 2. All hypothetical scenarios used to model tsunami runup in the Chignik area. Scenarios marked by an asterisk (*) indicate scenarios described in the Dutch Harbor/Unalaska modeling study by Nicolsky and others (2015). The number of the scenario in Nicolsky and others (2015) is stated in the parentheses after the asterisk.

\begin{tabular}{|c|c|c|c|c|c|c|c|c|c|}
\hline & Tectonic Scenarios & $\begin{array}{c}\text { Depth } \\
\text { range } \\
(\mathrm{km})\end{array}$ & $\begin{array}{l}\text { Maximum } \\
\text { slip depth } \\
\text { range } \\
(\mathrm{km})\end{array}$ & $\begin{array}{c}\text { Maximum } \\
\text { slip } \\
\text { (m) }\end{array}$ & $\begin{array}{l}\text { Maximum } \\
\text { subsid- } \\
\text { ence } \\
\text { (m) }\end{array}$ & $\begin{array}{c}\text { Maximum } \\
\text { uplift } \\
\text { (m) }\end{array}$ & $\begin{array}{c}\text { Vertical } \\
\text { displace- } \\
\text { ment } \\
\text { (m) }\end{array}$ & $\begin{array}{c}\text { Anderson St., } \\
\text { Chignik Bay } \\
\text { Maximum } \\
\text { water depth } \\
\text { (m) }\end{array}$ & \begin{tabular}{|c|} 
Henry St., \\
Chignik Lagoon \\
Maximum \\
water depth \\
(m)
\end{tabular} \\
\hline 1 & $\begin{array}{l}\mathrm{M}_{\mathrm{w}} 8.9 \text { earthquake along } \\
\text { Alaska Peninsula, } 30 \mathrm{~km} \\
\text { depth }\end{array}$ & $10-50$ & $28-32$ & 35 & 4.7 & 9.5 & -1.4 & 17.7 & 8.8 \\
\hline 2 & $\begin{array}{l}\mathrm{M}_{\mathrm{w}} 8.9 \text { earthquake along } \\
\text { Alaska Peninsula, } 25 \mathrm{~km} \\
\text { depth }\end{array}$ & $10-50$ & $23-27$ & 35 & 4.5 & 10.3 & -1.0 & 17.3 & 7.0 \\
\hline 3 & $\begin{array}{l}\mathrm{M}_{\mathrm{w}} 8.9 \text { earthquake along } \\
\text { Alaska Peninsula, } 35 \mathrm{~km} \\
\text { depth }\end{array}$ & $10-50$ & $33-37$ & 35 & 5.0 & 9.8 & -2.0 & 16.8 & 9.2 \\
\hline 4 & $\begin{array}{l}M_{w} 9.0 \text { earthquake along } \\
\text { Alaska Peninsula, } 10 \mathrm{~km} \\
\text { depth }\end{array}$ & $5-35$ & $8-12$ & 55 & 6.8 & 19.1 & -0.1 & 29.8 & 9.3 \\
\hline 5 & $\begin{array}{l}M_{w} 9.0 \text { earthquake along } \\
\text { Alaska Peninsula, } 13 \mathrm{~km} \\
\text { depth }\end{array}$ & $5-35$ & $11-15$ & 55 & 7.8 & 16.8 & -0.1 & 30.7 & 10.7 \\
\hline 6 & $\begin{array}{l}M_{w} 9.0 \text { earthquake along } \\
\text { Alaska Peninsula, } 17 \mathrm{~km} \\
\text { depth }\end{array}$ & $5-35$ & $15-19$ & 45 & 7.0 & 12.4 & -0.2 & 22.1 & 9.7 \\
\hline $7^{*(4)}$ & $\begin{array}{l}\mathrm{M}_{\mathrm{w}} 9.0 \text { earthquake } \\
\text { according to SAFRR } \\
\text { project }\end{array}$ & $8-54$ & $11-14$ & $55-65$ & 2.8 & 14.8 & -0.7 & 10.5 & 2.6 \\
\hline 8 & $\begin{array}{l}\mathrm{M}_{\mathrm{w}} 9.2 \text { Alaska Peninsula } \\
\text { earthquake }\end{array}$ & $7-50$ & $12-17$ & 45 & 5.6 & 13.3 & -2.4 & 12.7 & 6.9 \\
\hline 9 & $\begin{array}{l}M_{w} 9.25 \text { Alaska Peninsula } \\
\text { earthquake }\end{array}$ & $5-31$ & $5-18$ & 50 & 6.3 & 23.5 & -0.2 & 30.0 & 6.9 \\
\hline $10^{*(9)}$ & $\begin{array}{l}\mathrm{M}_{\mathrm{w}} 9.0-9.1 \text { earthquake in } \\
\text { the Cascadia subduction } \\
\text { zone }\end{array}$ & $\begin{array}{l}\text { Wang and } \\
\text { others, } \\
2003\end{array}$ & $\begin{array}{l}\text { Wang and } \\
\text { others, } \\
2003\end{array}$ & $35-45$ & 7.5 & 10.9 & 0.0 & 0.8 & 0.0 \\
\hline 11 & $\begin{array}{l}\mathrm{M}_{\mathrm{w}} 8.6 \text { outer-rise } \\
\text { earthquake along the } \\
\text { Alaska Peninsula }\end{array}$ & $2-23$ & $2-23$ & 25 & 13.9 & 2.5 & -0.1 & 1.9 & 0.0 \\
\hline
\end{tabular}

$\mathrm{B}, \mathrm{C}$, and D arrive in a short time interval. Therefore, the simultaneous rupture of the segments associated with cases $\mathrm{B}, \mathrm{C}$, and $\mathrm{D}$ might also produce waves that constructively interfere with each other.

On the basis of the results of this downdip sensitivity study, we find two rupture depth ranges that would likely have the most effect on tsunami height in Chignik. The first rupture depth range coincides with the slip patterns associated with cases $\mathrm{A}-\mathrm{C}$, while the second rupture depth range is related to cases B-D. Note that the considered cases represent hypothetical $\mathrm{M}_{\mathrm{W}}$ 7.1-7.2 earthquakes, and that much larger earthquakes are possible along the Alaska Peninsula (Wesson and others, 2008). As in Nicolsky and others (in press) we develop maximum credible scenarios for the Chignik area communities as follows: we assume a slip up to $35 \mathrm{~m}$ (115 ft) in the deep and intermediate sections of the megathrust and up to $55 \mathrm{~m}(180 \mathrm{ft})$ in the shallow sections of the megathrust, such as close to the trench, and we attribute the maximum value of the slip to areas around the patches which, when they rupture, result in the highest waves; the resulting waves could then constructively interfere with each other (Nicolsky and others, 2015). We emphasize that the assumed slip distribution is consistent with other modeling studies (for example, Butler, 2014) for the Alaska-Aleutian megathrust.

\section{EARTHQUAKE SCENARIOS}

Various downdip locations for the maximum slip are next considered to parameterize geologically credible $M_{W}$ 8.9-9.0 tsunamigenic earthquakes between Kodiak Island and the Shumagin Islands archipelago. Scenarios 1-3 model $\mathrm{M}_{\mathrm{W}} 8.9$ earthquakes with the rupture zone at the overlap of cases A-C such that the updip and downdip boundaries of the hypothetical ruptures are assumed to be at $10 \mathrm{~km}$ $(6.2 \mathrm{mi})$ and $50 \mathrm{~km}(31 \mathrm{mi})$, respectively. In the downdip direction, the slip is parameterized using the specifications of Freund and Barnett (1976). The maximum slip is assumed to be located at a different depth for each scenario. Similarly, scenarios 4-6 simulate $M_{W} 9.0$ earthquakes with the rupture zone at the overlap of cases B-D such that the updip and downdip boundaries of rupture boundaries are assumed to be at $5 \mathrm{~km}(3.1 \mathrm{mi})$ and $35 \mathrm{~km}(21.7 \mathrm{mi})$, respectively. For these scenarios, we also apply a parameterization of slip by 
Freund and Barnett (1976), with maximum slip located at different depths. Finally, previously examined earthquakes (Nicolsky and others, 2015) are considered in scenarios 7-10. All examined scenarios are summarized in table 2.

Scenario 1: $\mathrm{M}_{\mathrm{W}} 8.9$ earthquake along the Alaska Peninsula, $30 \mathrm{~km}$ (18.6 mi) depth

This event is a hypothetical $\mathrm{M}_{\mathrm{W}} 8.9$ earthquake rupturing the Aleutian megathrust at the 1938 aftershock area. The slip is uniformly distributed in the along-strike direction of the plate interface from Kodiak Island to the Shumagin Islands archipelago and is tapered on both ends of the rupture. A symmetrical bell-type slip curve, related to Freund and Barnett's (1765) slip skewness parameter, $q=$ 0.5 , is assumed in the downdip direction. The maximum

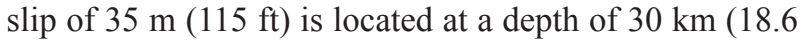
$\mathrm{mi}$ ), which corresponds to sensitivity case B. The proposed slip distribution is shown in figure 9A; vertical coseismic deformations for this scenario are shown in figure 10A.

Note that scenario 1 represents only one of many possible slip patterns associated with a combination of cases A-C. There are multiple possibilities for the slip distribution between the $10 \mathrm{~km}(6.2 \mathrm{mi})$ and $50 \mathrm{~km}(31 \mathrm{mi})$ depth that result in similar (lesser and greater) maximum wave heights in Chignik. Therefore, to ensure we do not overlook other relevant scenarios, we supplement scenario 1 with scenarios 2 and 3 , which have a slightly skewed bell-type slip curve in the downdip direction. As in scenario 1, scenarios 2 and 3 model a hypothetical $\mathrm{M}_{\mathrm{W}} 8.9$ earthquake rupturing the Aleutian megathrust at the 1938 aftershock area, but place maximum slip at depths different from the one used in scenario 1.

\section{Scenario 2: $\mathrm{M}_{\mathrm{W}} 8.9$ earthquake along the Alaska Penin-} sula, $25 \mathrm{~km}$ (15.5 mi) depth

The slip skewness parameter, $q$, is set to 0.33 to model the maximum slip of $35 \mathrm{~m}(115 \mathrm{ft})$ at a depth of $25 \mathrm{~km}$ (15.5 mi). This depth corresponds to the average depth of sensitivity cases B and C. The proposed slip distribution is shown in figure 9B; vertical coseismic deformations for this scenario are shown in figure 10B.

Scenario 3: $\mathrm{M}_{\mathrm{W}} 8.9$ earthquake along the Alaska Peninsula, $35 \mathrm{~km}$ (21.7 mi) depth

The slip skewness parameter, $q$, is set to 0.66 to model the maximum slip of $35 \mathrm{~m}(115 \mathrm{ft})$ at a depth of $35 \mathrm{~km}$ (21.7 mi). This depth corresponds to the average depth of sensitivity cases A and B. The proposed slip distribution is shown in figure 9C; vertical coseismic deformations for this scenario are shown in figure $10 \mathrm{C}$.

Recall that other ruptures associated with cases B-D would likely also trigger large devastating tsunamis. The following scenarios 4-6 simulate Mw 9.0 earthquakes with the rupture zone at the overlap of cases B-D such that the updip and downdip boundaries of rupture boundaries are assumed to be at $5 \mathrm{~km}(3.1 \mathrm{mi})$ and $35 \mathrm{~km}(21.7 \mathrm{mi})$, respectively. In light of the recent $\mathrm{M}_{\mathrm{W}} 9.0$ earthquake off the Pacific coast of Tohoku in 2011, we consider tsunami scenarios with a large amount of slip near the trench.

Scenario 4: $M_{\mathrm{W}} 9.0$ earthquake along the Alaska Peninsula, $10 \mathrm{~km}$ (6.2 mi) depth

This event is a hypothetical $M_{W} 9.0$ earthquake rupturing the Aleutian megathrust at the 1938 aftershock area. As in the previous scenarios, the slip is uniformly distributed in the along-strike direction of the plate interface from Kodiak Island to the Shumagin Islands archipelago and is tapered on both ends of the rupture. However, the location of the hypothetical slip is closer to the trench. The slip skewness parameter, $q$, is set to 0.15 to model the maximum slip of $55 \mathrm{~m}(180 \mathrm{ft})$ at a depth of $10 \mathrm{~km}(6.2 \mathrm{mi})$. This depth corresponds to the average depth for cases $\mathrm{C}$ and $\mathrm{D}$. The proposed slip distribution is shown in figure 9D; vertical coseismic deformations for this scenario are shown in figure 10D.

To account for potential variations in the depth of the slip distribution, in scenarios 5 and 6 we consider several modifications of the slip pattern in scenario 4. As in scenario 4 , scenarios 5 and 6 also model a hypothetical $M_{W} 9.0$ earthquake rupturing the Aleutian megathrust at the 1938 aftershock area, and have a skewed bell-type slip curve in the downdip direction.

\section{Scenario 5: $M_{W} 9.0$ earthquake along the Alaska Penin- sula, $13 \mathrm{~km}$ (8.1 mi) depth}

The slip skewness parameter, $q$, is set to 0.25 to model the maximum slip of $55 \mathrm{~m}$ (180 ft) at a depth of $13 \mathrm{~km}(8.1 \mathrm{mi})$. This depth corresponds to the average depth of sensitivity for cases B, C, and D. The proposed slip distribution is shown in figure 9E; vertical coseismic deformations for this scenario are shown in figure $10 \mathrm{E}$.

Scenario 6: $\mathrm{M}_{\mathrm{W}} 9.0$ earthquake along the Alaska Peninsula, 17 km (10.6 mi) depth

The slip skewness parameter, $q$, is set to 0.35 to model the maximum slip of $45 \mathrm{~m}$ (148 ft) at a depth of $17 \mathrm{~km}(10.6$ $\mathrm{mi})$. Similar to the previous scenario, the rupture depth corresponds to the average depth of sensitivity for cases B, C, and $\mathrm{D}$; however the slip skewness parameter, $\mathrm{q}$, now places the maximum slip at the different depth. The proposed slip distribution is shown in figure 9F; vertical coseismic deformations for this scenario are shown in figure $10 \mathrm{~F}$.

As in previous tsunami modeling studies (Nicolsky and others, 2015), we simulate tsunami runup in the Chignik area based on the USGS Science Application for Risk Reduction (SAFRR) project (scenario 7), two scenarios based on the research of Butler and others (2014) (scenarios 8 and 9), a rupture of the Cascadia zone (scenario 10), and a hypothetical $\mathrm{M}_{\mathrm{W}} 8.6$ outer-rise event (scenario 11). Scenarios marked by an asterisk are the same as in Nicolsky and others (2015). 


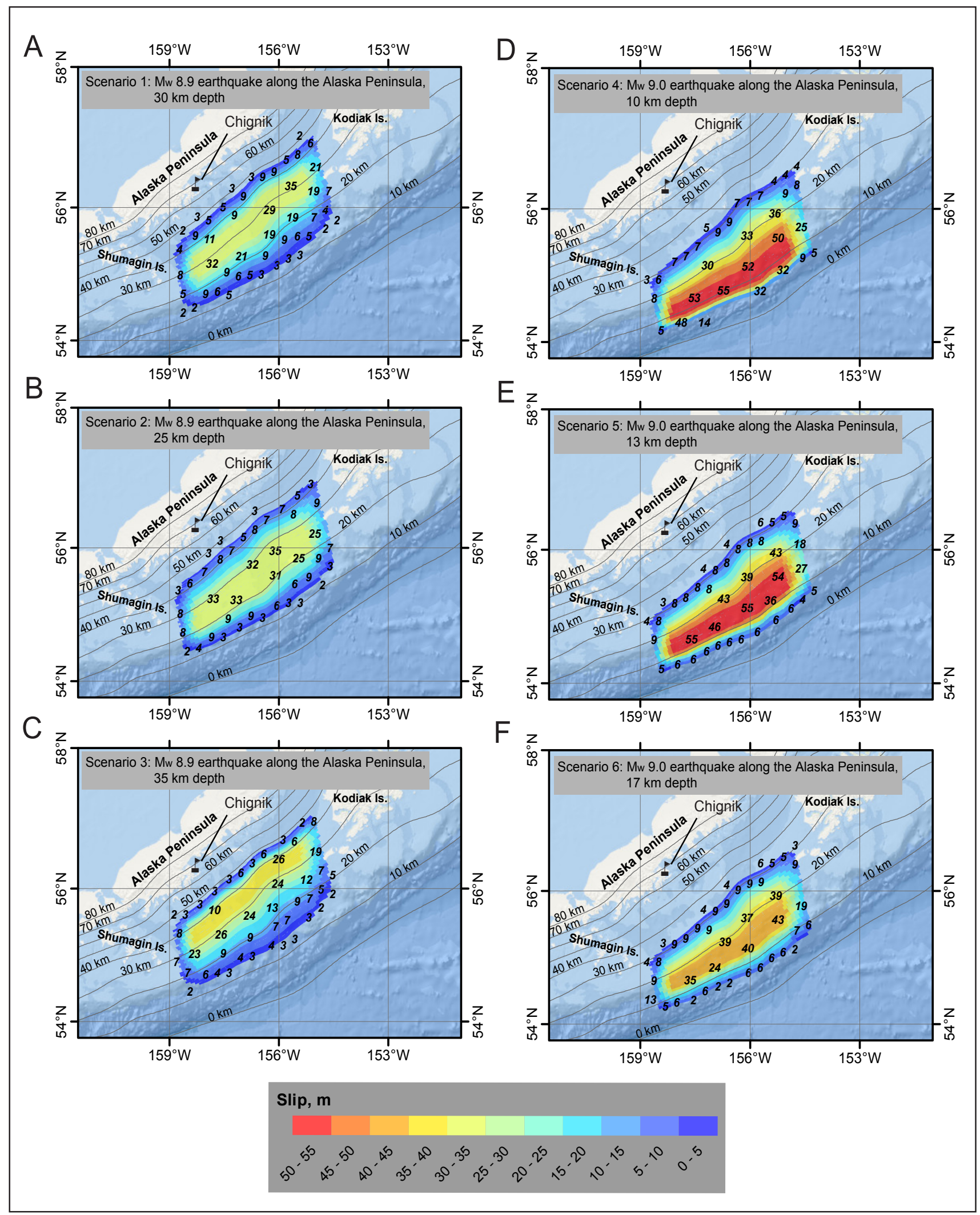

Figure 9. Proposed slip distribution along the plate interface for: (A) Scenario 1, hypothetical Mw 8.9 earthquake along the Alaska Peninsula, $30 \mathrm{~km}$ (18.6 mi) depth. (B) Scenario 2, hypothetical Mw 8.9 earthquake along the Alaska Peninsula, $25 \mathrm{~km}$ (15.5 mi) depth. (C) Scenario 3, hypothetical Mw 8.9 earthquake along the Alaska Peninsula, $35 \mathrm{~km}$ (21.7 mi) depth. (D) Scenario 4, hypothetical Mw 9.0 earthquake along the Alaska Peninsula, $10 \mathrm{~km}$ (6.2 mi) depth. (E) Scenario 5, hypothetical Mw 9.0 earthquake along the Alaska Peninsula, $13 \mathrm{~km}$ (8.1 mi) depth. (F) Scenario 6, hypothetical Mw 9.0 earthquake along the Alaska Peninsula, 17 km (10.6 mi) depth. 


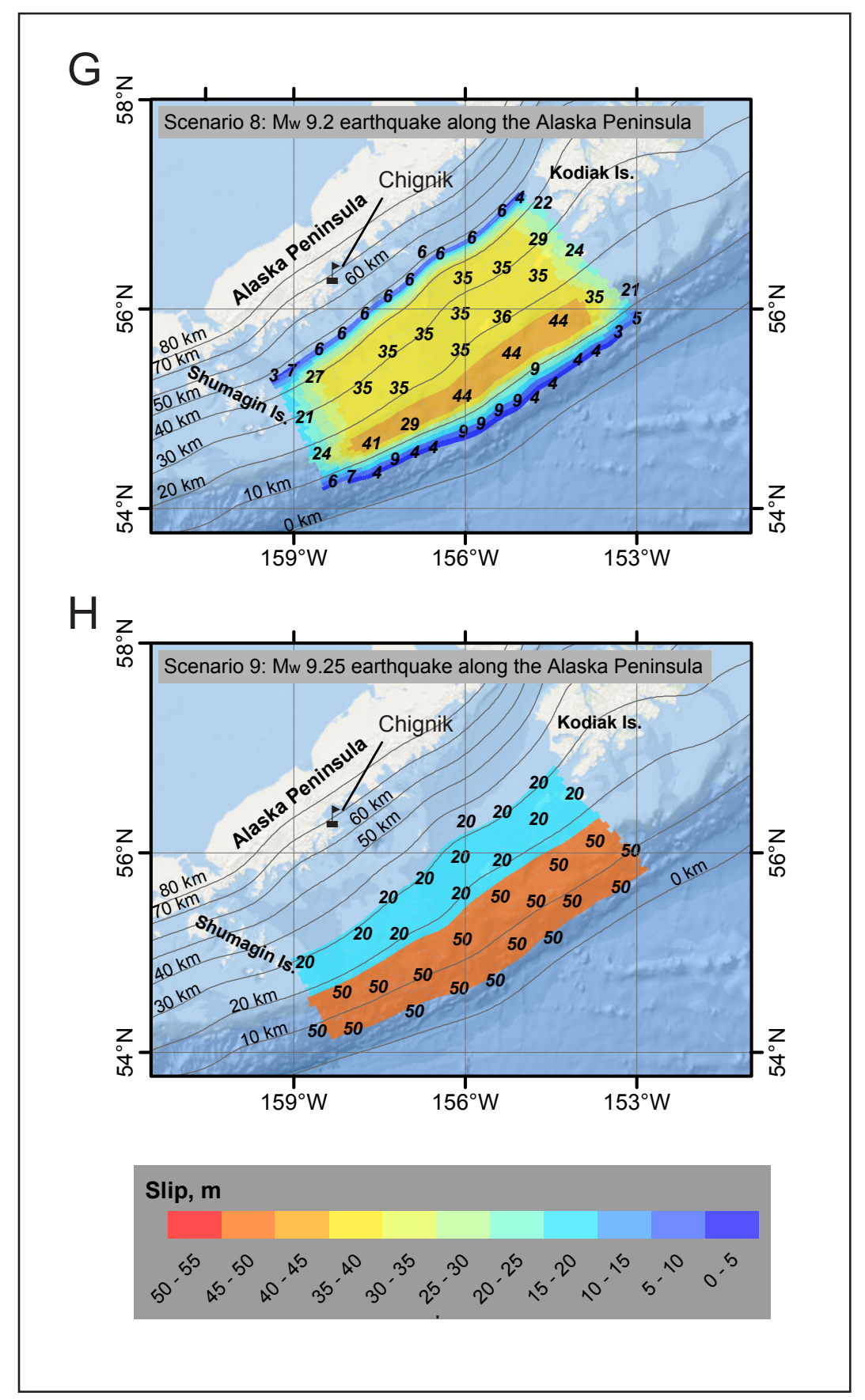

Figure 9, continued. Proposed slip distribution along the plate interface for: (G) Scenario 8, hypothetical Mw 9.2 earthquake along the Alaska Peninsula. (H) Scenario 9, hypothetical Mw 9.25 earthquake along the Alaska Peninsula. The proposed slip distribution along the plate interface is uniform in the along-strike direction and is slightly tapered at both ends of the potential rupture. Slip values in meters are marked by small black labels. The depth contours of the Aleutian interface are shown by colored lines. The assumed slip distribution for scenario 7 is shown in figure 22D of Nicolsky and others (2015). Slip distributions are not provided for scenarios 10 and 11 . 


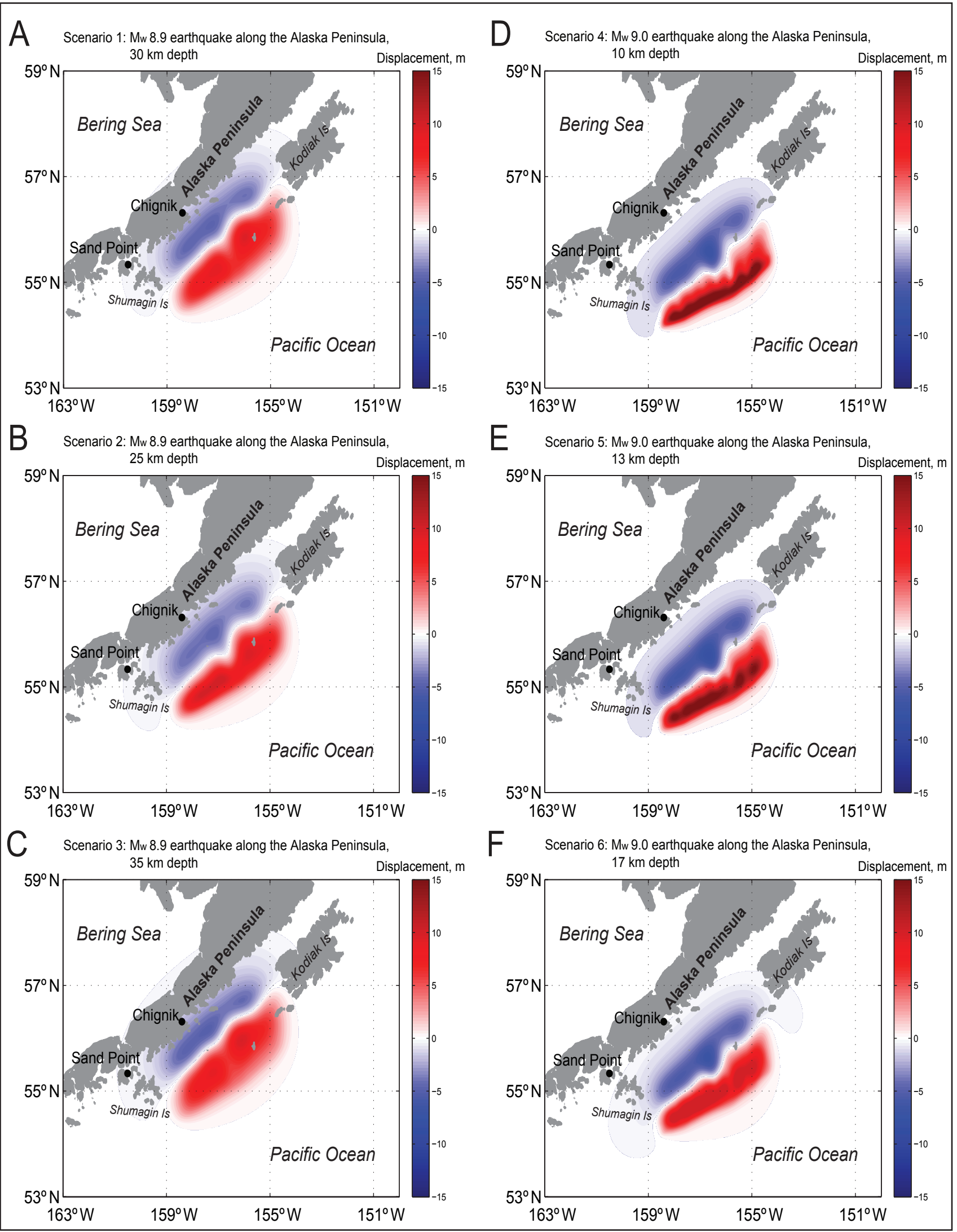

Figure 10. Computed vertical ground-surface deformation related to the proposed slip distributions shown on figure 9 (fig. 10A-H) and an outer rise event (fig. 10l). Blue shaded areas are associated with coseismic ground subsidence; areas of uplift are shown in red. Vertical ground surface deformation for scenarios 7 and 10 are shown in figures 23D and 23l of Nicolsky and others (2015). 
$G$ Scenario 8: Mw 9.2 earthquake along the Alaska Peninsula

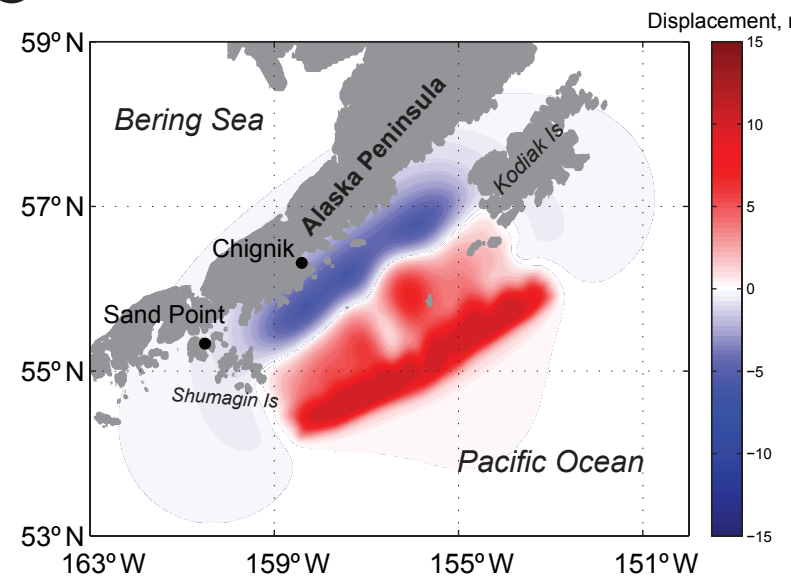

H Scenario 9: Mw 9.25 earthquake along the Alaska Peninsula

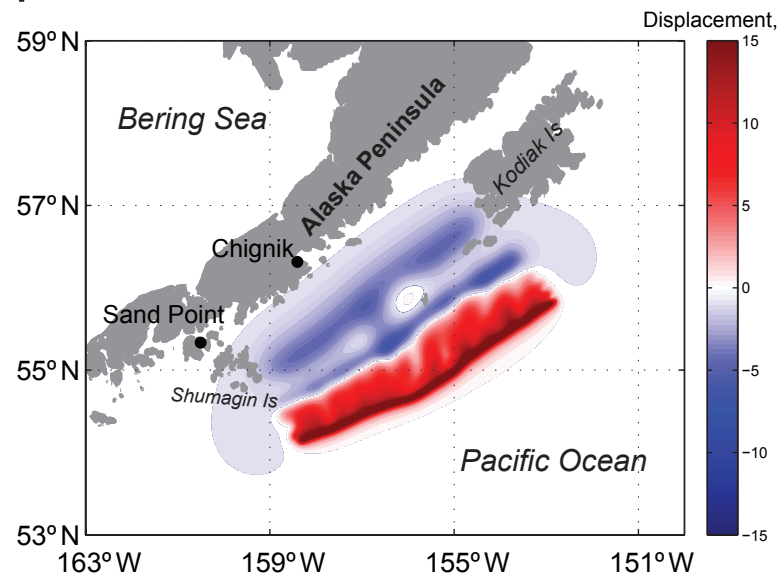

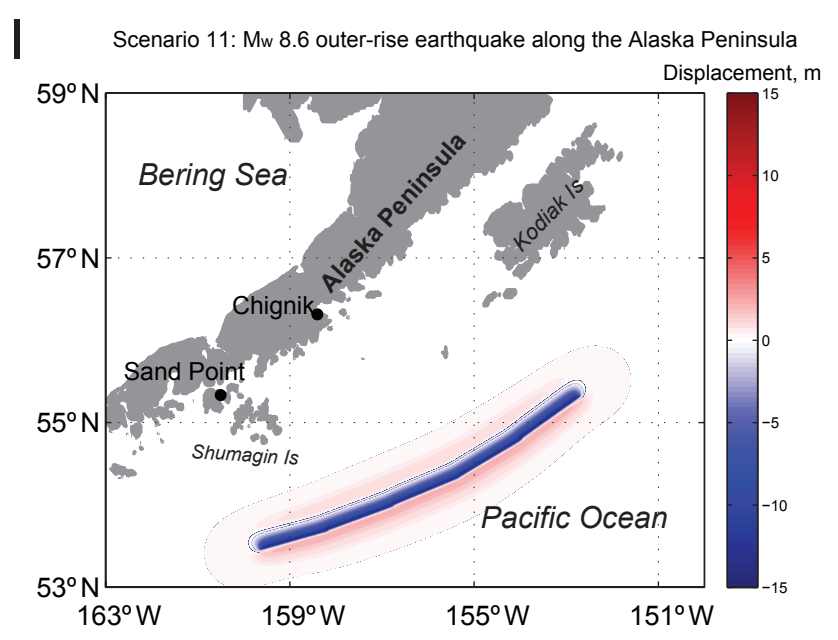

Figure 10, continued. Computed vertical ground-surface deformation related to the proposed slip distributions shown on figure 9 (fig. $10 \mathrm{~A}-\mathrm{H}$ ) and an outer rise event (fig. 10I). Blue shaded areas are associated with coseismic ground subsidence; areas of uplift are shown in red. Vertical ground surface deformation for scenarios 7 and 10 are shown in figures 23D and 23l of Nicolsky and others (2015). 


\section{Scenario 7: $M_{W} 9.0$ earthquake according to the SAFRR project*}

The USGS Science Application for Risk Reduction (SAFRR) project, in collaboration with NOAA and State of California agencies, has developed a plausible hypothetical tsunami scenario (Kirby and others, 2013) to describe the impacts of a tsunami generated by an earthquake in the Alaska Peninsula region (Ross and others, 2013). This scenario is the same as scenario 4 in the tsunami modeling study for Unalaska/ Dutch Harbor by Nikolsky and others (2015). The assumed slip distribution is shown in Nicolsky and others (2015, fig. 22D); the coseismic deformations for this scenario are shown in Nicolsky and others (2015, fig. 23D).

A recent study by Butler and others (2014) describes a layer of sand that was discovered in the Makauwahi sinkhole on the Island of Kaua'i, Hawai'i. The origin of this layer is attributed to inundation of the sinkhole by a giant paleotsunami following a $\mathrm{M}_{\mathrm{W}}$ 9+ earthquake in the eastern Aleutian Islands. Butler (2012) provides an in-depth examination of previous great Aleutian earthquakes and tsunamis impacting Hawai'i. In subsequent research Butler (2014) considered several hypothetical events with a $35 \mathrm{~m}$ (115 ft) displacement on the megathrust and up to a $50 \mathrm{~m}$ (164 ft) displacement near the trench. We assume that similar hypothetical events might occur along the Alaska Peninsula and consider the following two scenarios.

\section{Scenario 8: $\mathrm{M}_{\mathrm{W}}$ 9.2 Alaska Peninsula earthquake}

In this scenario we assume $35 \mathrm{~m}(115 \mathrm{ft})$ slip on the plate interface and up to a $46 \mathrm{~m}(151 \mathrm{ft})$ slip near the trench. The slip is distributed almost uniformly along strike between the Shumagin Islands and Kodiak Island except for the edges of the rupture, where it tapers. The proposed slip distribution is shown in figure $9 \mathrm{G}$; vertical coseismic deformations for this scenario are shown in figure $10 \mathrm{G}$. A similar scenario was proposed in the tsunami modeling study for Unalaska/Dutch Harbor (scenario 6 of Nicolsky and others, 2015, fig. 22G).

\section{Scenario 9: $M_{W} 9.25$ Alaska Peninsula earthquake}

In this scenario similar to Butler (2014) we assume a $20 \mathrm{~m}(65.6$ $\mathrm{ft})$ slip on the plate interface between the $17.9 \mathrm{~km}(11.1 \mathrm{mi})$ and $30.8 \mathrm{~km}$ (19.1 mi) depth, and up to a $50 \mathrm{~m}$ (164 ft) slip near the trench between $5 \mathrm{~km}(3.1 \mathrm{mi})$ and $17.9 \mathrm{~km}$ (11.1 mi) depth. The slip is distributed uniformly along strike between the Shumagin Islands and Kodiak Island. The proposed slip distribution is shown in figure $9 \mathrm{H}$; vertical coseismic deformations for this scenario are shown in figure $10 \mathrm{H}$. A similar scenario was proposed in the tsunami modeling study for Unalaska/Dutch Harbor (scenario 7 of Nicolsky and others, 2015, fig. 22H).

Although a rupture of the Cascadia zone is not a worst-case scenario for Chignik, in the interest of community preparedness we also simulate a large hypothetical earthquake along the western seaboard of the U.S.
Scenario 10: Mw 9.0-9.1 earthquake in the Cascadia subduction zone*

This scenario modes a rupture of the Cascadia zone, including the entire megathrust between British Columbia and northern California and is the same as scenario 9 in the tsunami modeling studies for Unalaska/Dutch Harbor and Sand Point. The vertical coseismic deformations for this scenario are shown in Nicolsky and others (2015, fig. 23I).

Finally, we note that outer-rise earthquakes are known to have occurred in the subducting plate in the vicinity of the oceanic trench (Stauder, 1968; Byrne and others, 1988). Great tensional outer-rise events occurred near Japan on March 2, 1933 (the $\mathrm{M}_{\mathrm{W}}$ 8.4 Sanriku-oki earthquake [Kanamori, 1971]) and near Indonesia on August 19, 1977 (the $\mathrm{M}_{\mathrm{W}}$ 8.3 Sumba earthquake [Gusman and others, 2009]). Because at least 24 significant outer-rise events have occurred along the AlaskaAleutian Arc (Christensen and Ruff, 1988), we simulate a large hypothetical outer-rise earthquake in our modeling.

Scenario 11: Mw 8.6 outer-rise earthquake along the Alaska Peninsula

We consider a hypothetical $\mathrm{M}_{\mathrm{W}} 8.6$ outer-rise event parallel to the Alaska Peninsula and parameterize it by five subfaults, listed in table 3 . The fault parameters required to compute seafloor deformation are the epicenter location, area, dip, rake, strike, and amount of slip on the fault. We use the equations of Okada (1985) to calculate distribution of coseismic uplift and subsidence resulting from this slip distribution. The dip of each subfault is in a range reported by Stauder (1968), and we assume that the hypothetical earthquake ruptures through the entire slab. Vertical coseismic deformations for this scenario are shown in figure 10I.

\section{MODELING RESULTS}

We performed numerical calculations for each of the 11 hypothetical earthquake scenarios. Water dynamics are modeled in each grid (listed in table 1) and we compute the extent of inundation only in the high-resolution grids. The simulated extents of inundation in Chignik and Chignik Lagoon for all considered scenarios are shown in figures 11A and $11 \mathrm{~B}$, respectively, as well as the locations of water-level stations used in computations of wave heights. The predicted maximum wave heights and water velocities are listed for a number of locations around Chignik Bay and Chignik Lagoon in Tables A-1 and B-1, respectively.

We begin discussion of the modeling results by examining scenarios 1-3, in which tsunamis are triggered by hypothetical $\mathrm{M}_{\mathrm{W}} 8.9$ earthquakes. We note that this group of hypothetical earthquakes results in 18-20 m (59-66 ft) waves at the computational station in Anchorage Bay (fig. 12A). In Chignik Lagoon, on the northeast side of the village, the waves at the computational station may reach up to $12 \mathrm{~m}$ (39 ft) (fig. 13A). Scenarios 1-3 display similar waves with the maximum crest arriving about 1 hour after the earth- 
quake. The numerical experiments reveal that the first crest of the tsunami in Anchorage Bay is followed by an 18-20 m (59-66 ft) withdrawal of the ocean. Significant wave activity continues for at least 12 hours after the earthquake, with waves reaching $5 \mathrm{~m}(16 \mathrm{ft})$ above pre-earthquake sea level. Unlike Anchorage Bay, Chignik Lagoon is a shallow water body and the leading wave of the tsunami, when it arrives at the lagoon, starts to steepen and eventually becomes a bore as it approaches and runs ashore. Note the abrupt increase in the modeled sea level shortly after 1 hour, shown in figure 13A. In the numerical experiment, the tsunami overwhelms Chignik Lagoon and then water drains back to the ocean over the next 12 hours. Scenarios 1-3 all produce devastating flooding in both communities, and all near-coast infrastructure and buildings are likely to be affected.

The $\mathrm{M}_{\mathrm{W}} 9.0$ hypothetical earthquakes in scenarios 4-6 result in the largest waves of all the numerical experiments conducted. The highest waves in Anchorage Bay for these scenarios occur approximately 1 hour 45 minutes after the earthquake and reach between $20 \mathrm{~m}(66 \mathrm{ft})$ and $25 \mathrm{~m}(82 \mathrm{ft})$ (fig. 12B). In the computer experiments, the waves completely inundate the city and the runway, and penetrate deep into gullies. Figure 11A shows that the only place that might escape flooding in Chignik is the community landfill on the western side of Anchorage Bay. Significant wave activity, with $20 \mathrm{~m}(66 \mathrm{ft})$ variations between the wave crests and troughs, occurs for at least 3 hours after the earthquake. The highest waves for scenarios 4-6 reach $15 \mathrm{~m}(49 \mathrm{ft})$ in Chignik Lagoon (fig. 13B). Again, note the dramatic water-level rise approximately 1 hour 45 minutes after the earthquake. Such an abrupt change in the water level is a typical sign of a tsunami bore. The computed water-level dynamics for scenarios 4-6 are similar to the dynamics simulated in scenarios $1-3$, where the village of Chignik Lagoon is flooded by a bore. For scenarios 4-6, the school, the runway, and almost all infrastructure in Chignik Lagoon are flooded (fig. 11B).

Scenario 7, a hypothetical Tohoku-type earthquake occurring between Shumagin Islands and Kodiak Island, predicts a $10 \mathrm{~m}(33 \mathrm{ft})$ wave in Anchorage Bay and a $6 \mathrm{~m}$ (20 ft) wave in Chignik Lagoon, resulting in severe flooding in both communities. The modeled water levels for Chignik and Chignik Lagoon are shown in figures $12 \mathrm{C}$ and $13 \mathrm{C}$. The hypothetical $\mathrm{M}_{\mathrm{W}} 9.2$ and $\mathrm{M}_{\mathrm{W}} 9.25$ earthquakes consid- ered in scenarios 8 and 9 , respectively, also produce severe inundation in both communities. The simulated inundation extent for scenario 9 is almost the same as the flooding areas predicted by scenarios 4 and 5 . Recall that scenarios 4 and 5 as well as scenario 9 assume a large amount of slip near the trench. At some locations the maximum modeled water level reaches 30-33 m (98-108 ft) above ground. The computed runup for scenarios 4-6 and 9 is comparable to the level of flooding during the 2011 Tohoku event in Japan, where water levels reached up to 35-40 m (115-131 ft) above sea level (EERI/ERI/ITST, 2011).

The hypothetical tsunamis modeled in scenarios 10 and 11 flood low-lying areas along the shoreline. The extent of hypothetical inundation in both communities from these hypothetical events is shown in figures $11 \mathrm{~A}$ and $11 \mathrm{~B}$. The maximum wave reaches up to 3-3.5 m (10-11.5 ft) in Anchorage Bay and the maximum wave is $2 \mathrm{~m}(6.6 \mathrm{ft})$ in Chignik Lagoon, as shown in figures 12D and 13D, respectively. Both scenarios predict a series of erratic waves, which could cause dangerous currents in Anchorage Bay and Chignik Lagoon. For scenario 10 , the numerical simulation again predicts a series of bore waves that propagate along Chignik Lagoon. The largest wave arrives at Chignik Lagoon about 6 hours after the earthquake and significant wave action could continue afterward for at least 8 hours. Note on figure 12D that the maximum wave for scenario 10 arrives at Anchorage Bay almost 8 hours after the first crest. The estimated extent of inundation for both communities is shown in figures 11A and 11B. All limits of inundation are included in the data distribution package associated with this report.

\section{TIME SERIES}

To help emergency managers assess the tsunami hazard for this area, we supplement the inundation maps with the time series of the modeled water level and velocity dynamics at certain locations around Chignik and Chignik Lagoon (Appendices A-1 and B-1, respectively). Scenarios 1-3 model tsunamis triggered by a group of hypothetical $\mathrm{M}_{\mathrm{W}} 8.9$ earthquakes that visually resemble each other, and thus simulated tsunami dynamics for these scenarios are rather similar (figs. 12A and 13A). Likewise, scenarios 4-6, which are related to a group of hypothetical $\mathrm{M}_{\mathrm{W}} 9.0$ earthquakes, exhibit comparable numerical results as illustrated in figures $12 \mathrm{~B}$ and $13 \mathrm{~B}$.

Table 3. Fault parameters for the hypothetical tensional $M_{W} 8.6$ outer-rise earthquake (scenario 11)

\begin{tabular}{|c|c|c|c|c|c|c|c|c|}
\hline $\begin{array}{c}\text { Latitude } \\
\left({ }^{\circ} \mathbf{N}\right)\end{array}$ & $\begin{array}{c}\text { Longitude } \\
\left({ }^{\circ} \mathbf{W}\right)\end{array}$ & $\begin{array}{c}\text { Depth } \\
(\mathbf{k m})\end{array}$ & $\begin{array}{c}\text { Length } \\
\mathbf{( k m})\end{array}$ & $\begin{array}{c}\text { Width } \\
(\mathbf{k m})\end{array}$ & $\begin{array}{c}\text { Strike } \\
\left({ }^{\circ}\right)\end{array}$ & $\begin{array}{c}\text { Dip } \\
\left({ }^{\circ}\right)\end{array}$ & $\begin{array}{c}\text { Rake } \\
\left({ }^{\circ}\right)\end{array}$ & $\begin{array}{c}\text { Slip } \\
(\mathbf{m})\end{array}$ \\
\hline $55^{\circ} 19^{\prime} 08.4^{\prime \prime}$ & $152^{\circ} 40^{\prime} 58.8^{\prime \prime}$ & 2 & 100 & 15 & 235.00 & 45 & -90 & 25 \\
\hline $54^{\circ} 47^{\prime} 27.6^{\prime \prime}$ & $153^{\circ} 57^{\prime} 39.6^{\prime \prime}$ & 2 & 100 & 15 & 240.00 & 45 & -90 & 25 \\
\hline $54^{\circ} 19^{\prime} 51.6^{\prime \prime}$ & $155^{\circ} 19^{\prime} 04.8^{\prime \prime}$ & 2 & 100 & 15 & 248.26 & 45 & -90 & 25 \\
\hline $53^{\circ} 59^{\prime} 06.0^{\prime \prime}$ & $156^{\circ} 44^{\prime} 52.8^{\prime \prime}$ & 2 & 100 & 15 & 250.75 & 45 & -90 & 25 \\
\hline $53^{\circ} 40^{\prime} 48.0^{\prime \prime}$ & $158^{\circ} 11^{\prime} 06.0^{\prime \prime}$ & 2 & 100 & 15 & 255.17 & 45 & -90 & 25 \\
\hline
\end{tabular}




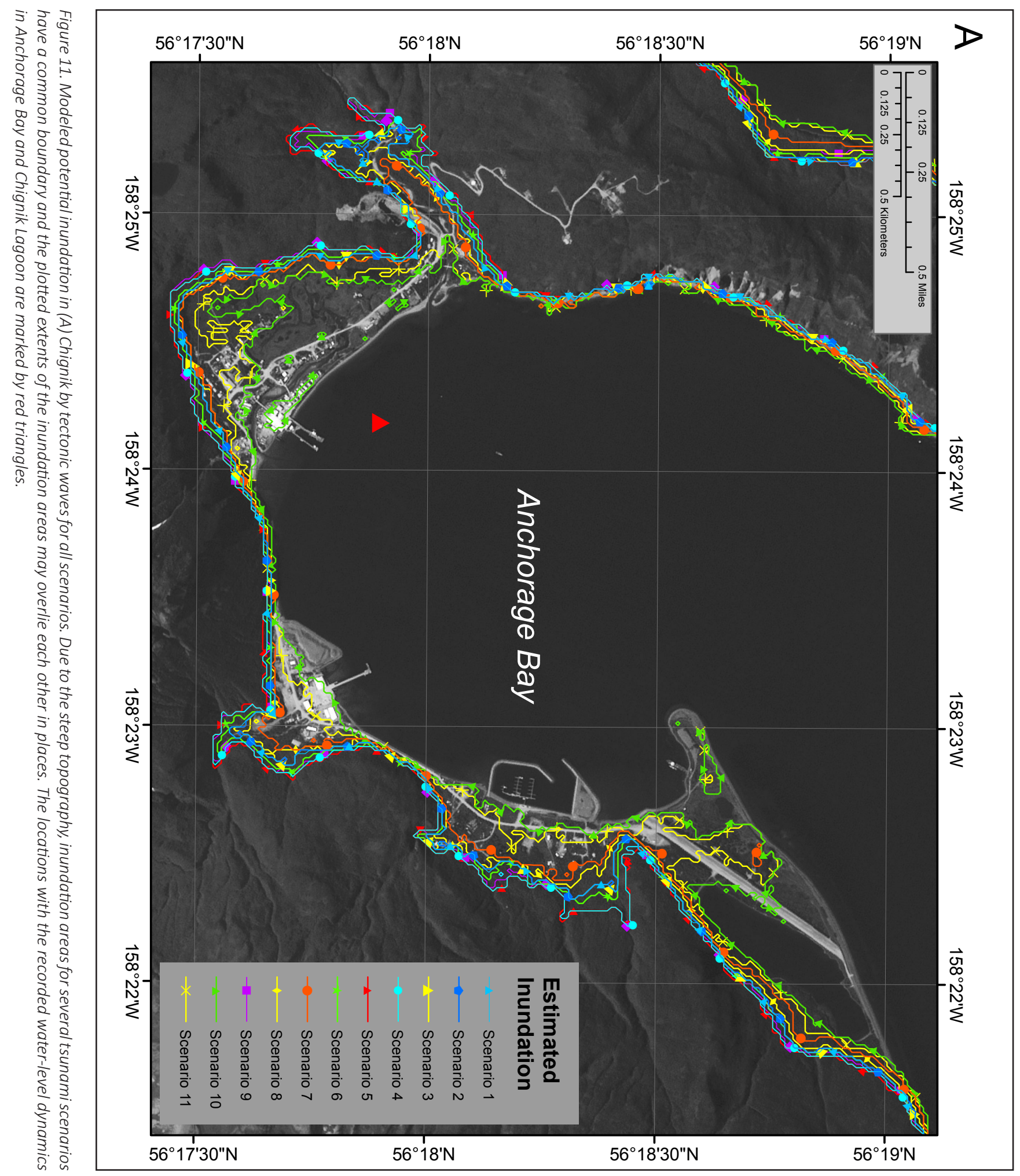




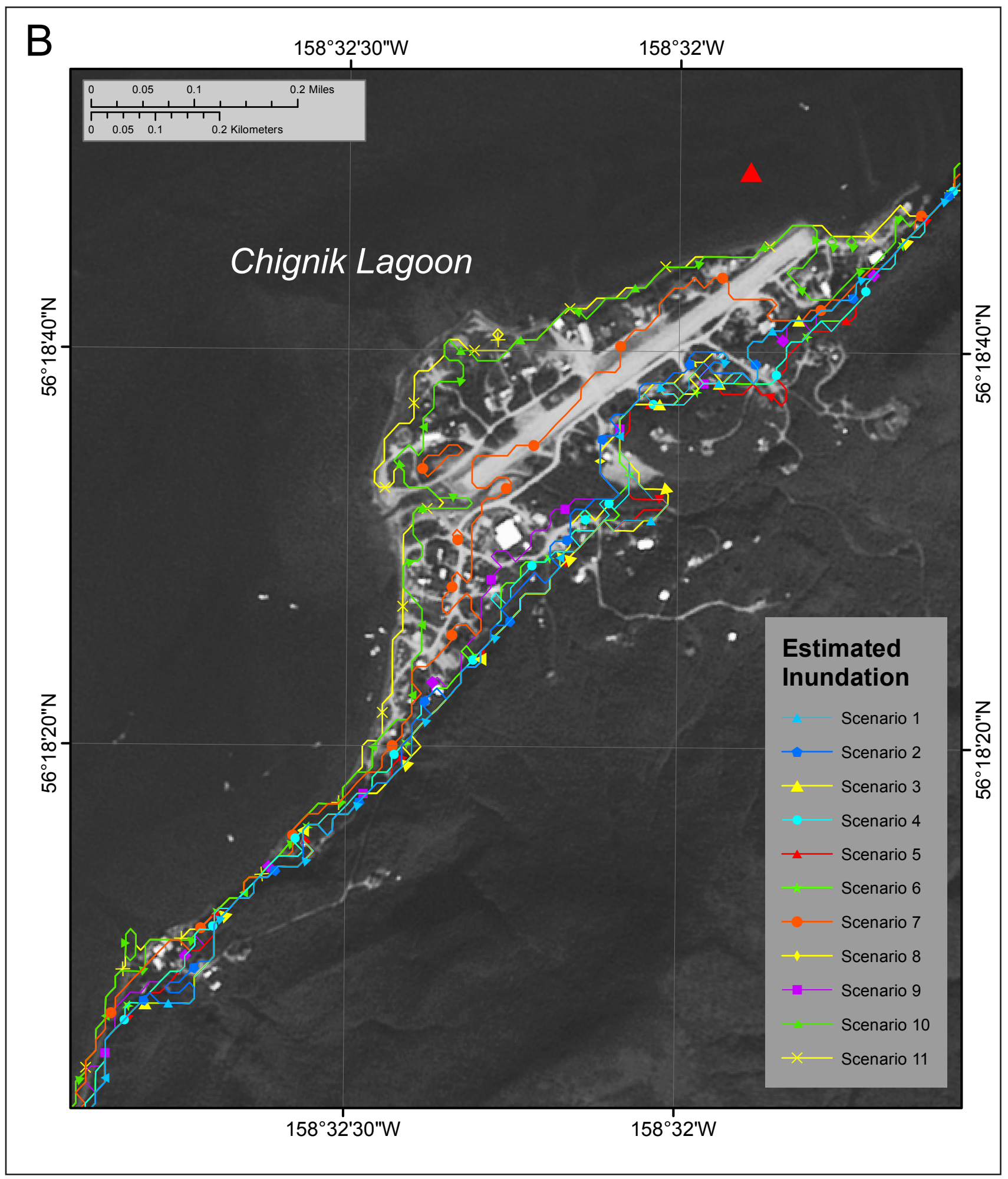

Figure 11, continued. Modeled potential inundation in (B) Chignik Lagoon by tectonic waves for all scenarios. Due to the steep topography, inundation areas for several tsunami scenarios have a common boundary and the plotted extents of the inundation areas may overlie each other in places. The locations with the recorded water-level dynamics in Anchorage Bay and Chignik Lagoon are marked by red triangles. 

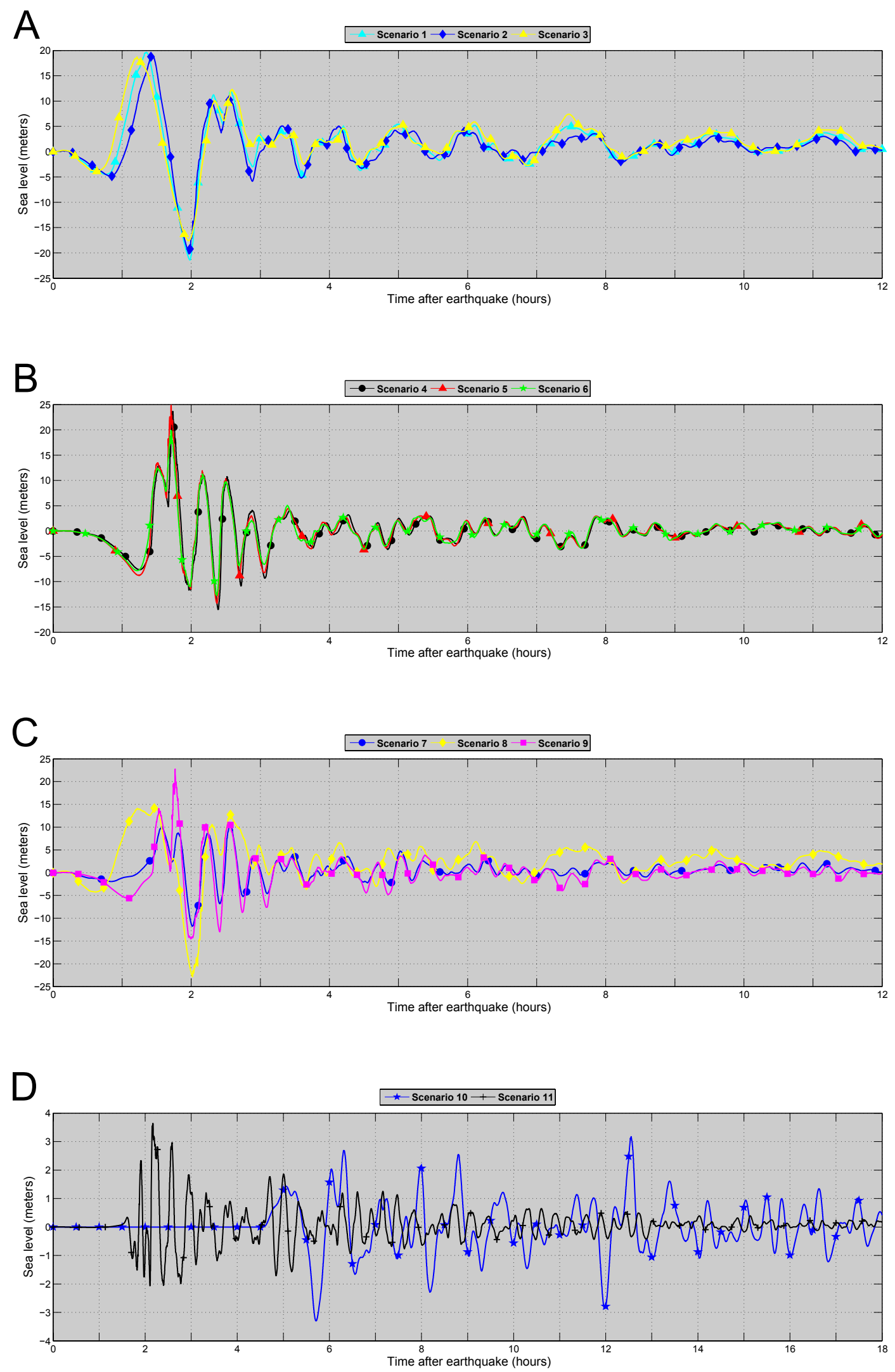

Figure 12. Modeled time series of water level in Anchorage Bay for (A) scenarios 1, 2, and 3; (B) scenarios 4, 5, and 6; (C) scenarios 7, 8, and 9; and (D) scenarios 10 and 11. The station location is marked by the red triangle in figure $11 \mathrm{~A}$. The vertical datum is such that zero corresponds to the pre-earthquake sea level. 

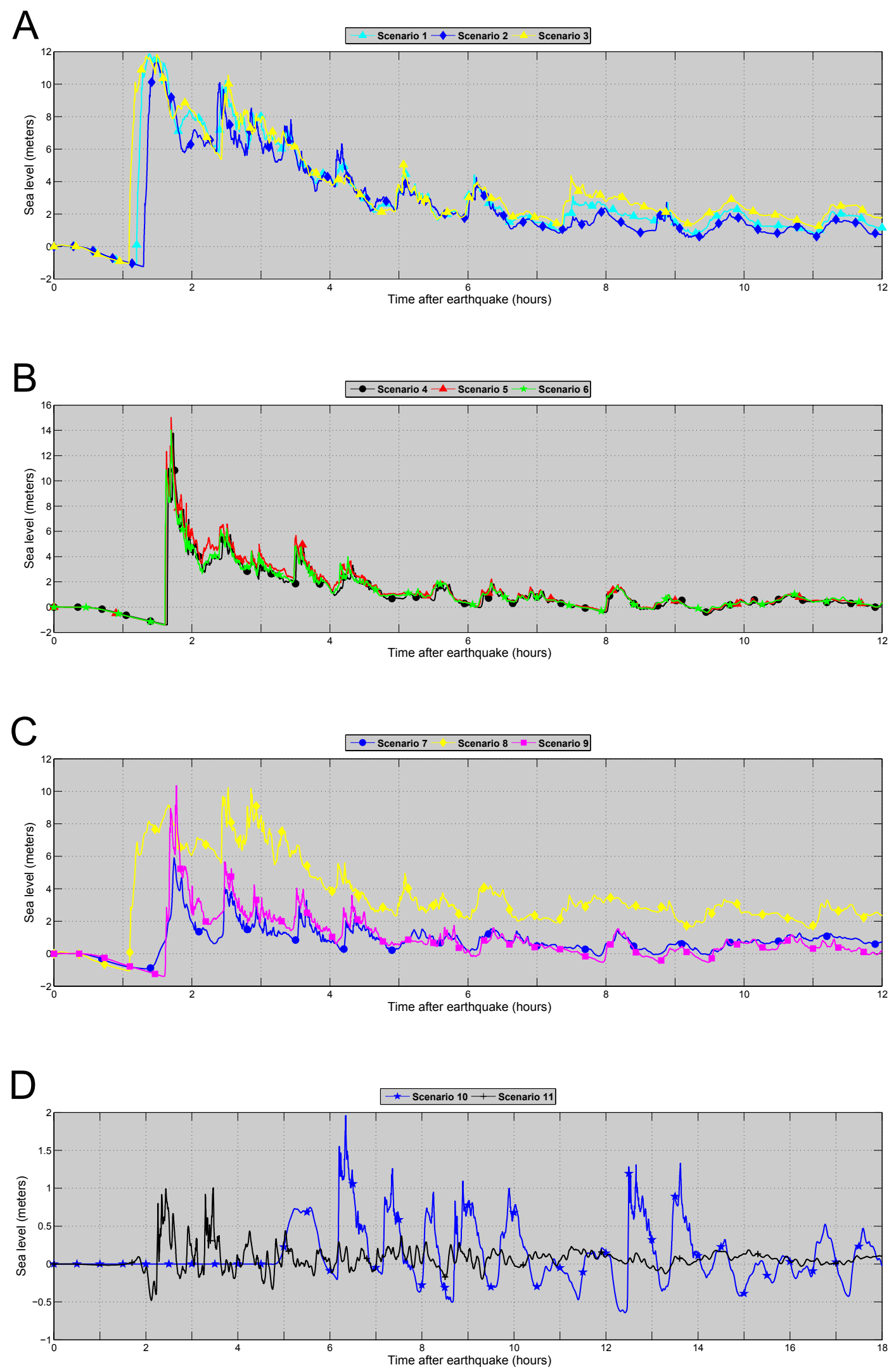

Figure 13. Modeled time series of water level in Chignik Lagoon for (A) scenarios 1, 2, and 3; (B) scenarios 4, 5, and 6; (C) scenarios 7, 8, and 9; and (D) scenarios 10 and 11. The station location is marked by the red triangle in figure $11 B$. The vertical datum is such that zero corresponds to the pre-earthquake sea level. 
Scenario 5 simulates the highest wave and is considered the worst-case scenario for both communities. Scenario 7 is extensively used in other tsunami hazard mitigation studies (Ross and others, 2013; Nicolsky and others, 2015), while scenario 9 predicts devastating tsunamis in both communities. Therefore, for the sake of brevity, for each labeled location in these figures we plot the sea level and water velocity for only scenarios $1,5,7$, and 9 .

In all plots in Appendices A-2 and B-2, zero time corresponds to the time when the earthquake occurs. The pre-earthquake elevation/depth with respect to the MHHW is stated for each location. The post-earthquake elevations/ depth corresponding to the MHHW datum are also listed for each scenario. To show the height of arriving tsunamis for offshore locations, we use a vertical datum with a zero mark corresponding to the pre-earthquake sea level. The dashed lines show water levels after the tsunami. The velocity magnitude is calculated as water flux divided by water depth, thus the velocity value can have large uncertainties when the water depth is small. In the plots provided, the velocity is computed only where the water depth is greater than $0.3 \mathrm{~m}(1 \mathrm{ft})$.

Analysis of the time series plot shows that a hypothetical earthquake with a magnitude of 8.9 can cause devastating waves that inundate the entire city of Chignik and flood the village of Chignik Lagoon. The maximum water level and velocity for all considered scenarios in both communities are listed in tables A-1 and B-1.

\section{SOURCES OF ERRORS AND UNCERTAINTIES}

The hydrodynamic model used to calculate propagation and runup of tsunami waves is a nonlinear, flux-formulated, shallow-water model (Nicolsky and others, 2011b) that has passed the validation and verification tests required for models used in production of tsunami inundation maps (Synolakis and others, 2007; NTHMP, 2012). Because of the shallow bathymetry in Chignik Lagoon, the hypothetical tsunami is likely to impact the village as a bore-a single, breaking wavefront followed by a train of secondary waves. Therefore, the so-called Boussinesq-type models (Nwogu, 1993; Kirby and others, 1998; Lynett and others, 2002) may be more appropriate in modeling propagation of these waves. However, it was illustrated in the 2011 NTHMP Model Validation Workshop (NTHMP, 2012; Horrillo and others, 2015) that the classical shallow-water models are probably adequate to predict the runup in most geophysical conditions. Further details about the limitations of the employed modeling approach are described in earlier reports by Suleimani and others $(2010,2013,2015)$ and Nicolsky and others (2011a, 2011b, 2013, 2014, 2015), as well as in NTHMP (2012). The accuracy of the later waves is limited by the accuracies of the bathymetry and coastline that are outside the extent of the high-resolution DEM but still impact the modeling.

\section{SUMMARY}

We present the results of numerical modeling of earthquake-generated tsunamis for Chignik and Chignik Lagoon, Alaska. The earthquake scenarios considered in this report include a range of magnitudes for the simultaneous rupture of the Semidi and Kodiak segments (listed as capable of producing M 8.5 and M 8.8 earthquakes, respectively) in the USGS Probabilistic Seismic Hazard Assessment for Alaska (Wesson and others, 2008). Hypothetical scenarios 4-6 ( $\mathrm{M}_{\mathrm{W}}$ 9.0 earthquakes along the Alaska Peninsula, with maximum slip near the trench) result in the "worst case" tsunamiinundation hazards for the Chignik area communities. Each of these considered scenarios predicts a devastating tsunami that could crush the entire City of Chignik Bay as a series of waves lasting for more than 3 hours, the first devastating wave may arrive sooner than one hour after the earthquake. Most of the Native village of Chignik Lagoon could be destructed by a $12 \mathrm{~m}$ (40 ft) bore wave arriving from the ocean and flooding the communities for several hours after its initial arrival.

We emphasize that each of the scenarios considered are geologically reasonable and present potential hazards to the communities. The maps in Sheets 1 and 2, showing the results of our modeling for Chignik and Chignik Lagoon, have been completed using the best information available and are believed to be accurate; however, their preparation required many assumptions. We considered a suite of tectonic scenarios and provide an estimate of maximum credible tsunami inundation for each scenario. Actual conditions during a tsunami event could vary from those considered, so the accuracy cannot be guaranteed. The limits of inundation shown should be used only as a guideline for emergency planning and response action. Actual areas inundated will depend on specifics of the earth deformation, land construction, and tide level, and may differ from areas shown on the map. The information on this map is intended to assist state and local agencies in planning emergency evacuation and tsunami response actions in the event of a major tsunamigenic earthquake. These results are not intended for land-use regulation or building-code development.

\section{ACKNOWLEDGMENTS}

This project received support from the National Oceanic and Atmospheric Administration (NOAA) under Reimbursable Service Agreements ADN 942017 and 952011 with the State of Alaska's Division of Homeland Security and Emergency Management (a division of the Department of Military and Veterans Affairs). Numerical calculations for this work were supported by a grant of High Performance Computing (HPC) resources from the Arctic Region Supercomputing Center (ARSC) at the University of Alaska Fairbanks. A thoughtful review by De Anne Stevens improved the report and maps. We also would like to thank Peter Hickman from the Geographic Information Network of Alaska (GINA) for help with selecting the base layer imagery. 


\section{REFERENCES}

Boyd, T.M., and Nabelek, J.L., 1988, Rupture process of the Andreanof Islands earthquake of May 7, 1986: Bulletin of the Seismological Society of America, v. 78, no. 5, p. 1,653-1,673.

Bryn, Petter, Berg, Kjell, Forsberg, C.F., Solheim, Anders, and Kvalstad, T.J., 2005, Explaining the Storegga slide: Marine and Petroleum Geology, v. 22, no. 1-2, p. 11-19. http://dx.doi.org/10.1016/j.marpetgeo.2004.12.003

Byrne, D.E., Davis, D.M., and Sykes, L.R., 1988, Loci and maximum size of thrust earthquakes and the mechanics of the shallow region of subduction zones: Tectonics, v. 7, no. 4, p. 833-857. http://dx.doi.org/10.1029/ TC007i004p00833

Butler, Rhett, 2012, Re-examination of the potential for great earthquakes along the Aleutian island arc with implication for tsunamis in Hawai'i: Seismological Research Letters, v. 83, no. 1, p. 30-39. http://dx.doi. org $/ 10.1785 / \mathrm{gssrl} .83 .1 .29$

Butler, Rhett, 2014, Great Aleutian tsunamis: Honolulu, HI, University of Hawai'i at Manoa, Hawai'i Institute of Geophysics \& Planetology, Peer-Reviewed Report HIGP-2014-1, 170 p., www.higp.hawaii.edu/reports/2014

Butler, Rhett, Burney, David, and Walsh, David, 2014, Paleotsunami evidence on Kaua'i and numerical modeling of a great Aleutian tsunami: Geophysical Research Letters, v. 41, no. 19, p. 6,795-6,802. http://dx.doi. org/10.1002/2014GL061232

Caldwell, R.J., Eakins, B.W., and Lim, E., 2011, Digital elevation model of Prince William Sound, AlaskaProcedures, data sources and analysis: National Geophysical Data Center, NOAA Technical Memorandum NESDIS NGDC-40, 41 p.

Carignan, K.S., McLean, S.J., Eakins, B.W., Love, M.R., and Sutherland, M., 2014, Digital elevation models of Chignik, Perryville, and Ivanof Bay, Alaska-Procedures, data sources, and analysis: Boulder, CO, NOAA National Centers for Environmental Information (NCEI).

Cloud, W.K., and Scott, N.H., 1969, Distribution of intensity, Prince William Sound earthquake of 1964, in Volume II B-C, The Prince William Sound earthquake of 1964 and aftershocks: Washington, DC, U.S. Coastal Geodetic Survey, Environmental Science Services Administration, p. 5-48.

Carver, G.A., and Plafker, George, 2008, Paleoseismicity and neotectonics of the Aleutian subduction zone-An overview, in Freymueller, J.T., Haeussler, P.J., Wesson, R.L, and Ekström, G., eds., Active tectonics and seismic potential of Alaska: American Geophysical Union Geophysical Monograph 179, p. 43-63.

Chignik Lagoon Village Council, 2004, Village of Chignik Lagoon-Strategic community development plan; Chignik, AK, Chignik Lagoon Village Council, prepared in consultation with A.N. Gottschalk \& Associates, 30 p.

Christensen, D.H., and Ruff, L.J., 1988, Seismic coupling and outer rise earthquakes: Journal of Geophysical
Research, v. 93, no. B11, p. 13,421-13,444, http://dx.doi. org/10.1029/JB093iB11p13421.

Cross, R.S., and Freymueller, J.T., 2008, Evidence for and implications of a Bering plate based on geodetic measurements from the Aleutians and western Alaska [abst.]: Journal of Geophysical Research, v. 113, no. B7, p. 405, http://dx.doi.org/10.1029/2007JB005136.

Davies, J.N., Sykes, L.R., House, L.S., and Jacob, K.H., 1981, Shumagin seismic gap, Alaska Peninsula-History of great earthquakes, tectonic setting, and evidence for high seismic potential: Journal of Geophysical Research, v. 86, no. B5, p. 3,821-3,855. http://dx.doi.org/10.1029/ JB086iB05p03821

Department of Commerce, Community, and Economic Development (DCCED)/Division of Community and Regional Affairs (DCRA), 2015, Community Database Online, accessed June 10, 2015. https://www.commerce. alaska.gov/dcra/DCRAExternal

Department of Commerce, Community, and Economic Development (DCCED)/Division of Community and Regional Affairs (DCRA), 2009, Community Plans online-Chignik Bay Community Plan: Alaska Division of Community and Regional Affairs. Accessed December 7, 2015, https://www.commerce.alaska.gov/dcra/DCR ARepoExt/RepoPubs/Plans/ChignikBay-CP-2006.pdf

Department of Commerce, Community, and Economic Development (DCCED)/Division of Community and Regional Affairs (DCRA), 2002, Community profile maps: Alaska Division of Community and Regional Affairs. Accessed December 7, 2015, https://www. commerce.alaska.gov/web/dcra/PlanningLandManage ment/CommunityProfileMaps.aspx

Dunbar, P.K., and Weaver, C.S., 2008, U.S. states and territories national tsunami hazard assessment-Historical record and sources for waves: Technical Report, National Oceanic and Atmospheric Administration and U.S. Geological Survey, 59 p. http://nthmp.tsunami.gov/doc uments/Tsunami_Assessment_Final.pdf

Earthquake Engineering Research Institute (EERI)/ERI/ ITST, 2011, The Japan Tohoku tsunami of March 11, 2011: Earthquake Engineering Research Institute Special Report Series, "Learning From Earthquakes," 15 p. Accessed December 7, 2015. http://www. eqclearinghouse.org/2011-03-11-sendai/files/2011/11/ Japan-eq-report-tsunami2.pdf

Fine, I.V., Rabinovich, A.B., Bornhold, B.D., Thompson, R.E., and Kulikov, E.A., 2005, The Grand Banks landslide-generated tsunami of November 18, 1929Preliminary analysis and numerical modeling: Marine Geology, v. 215, no. 1-2, p. 45-57. http://dx.doi. org/10.1016/j.margeo.2004.11.007

Freund, L.B., and Barnett, D.M., 1976, A two-dimensional analysis of surface deformation due to dip-slip faulting: Bulletin of the Seismological Society of America, v. 66, p. 667-675. 
Freymueller, J.T., Woodard, H., Cohen, S., Cross, R., Elliott, J., Larsen, C., Hreinsdottir, S., and Zweck, C., 2008, Active deformation processes in Alaska, based on 15 years of GPS measurements, in Freymueller, J.T., Haeussler, P.J., Wesson, R., and Ekström, G., eds., Active Tectonics and Seismic Potential of Alaska: Washington, DC, American Geophysical Union Geophysical Monograph, v. 179, p. 1-42. http://dx.doi.org/10.1029/179GM02

Grilli, S.T., Harris, J.C., Kirby, J.T., Shi, F., Ma, G., Masterlark, T., Tappin, D.R., and Tajali-Bakhsh, T.S., 2013, Modeling of the Tohoku-Oki 2011 tsunami generation, far-field and coastal impact-A mixed co-seismic and SMF source, in Bonneton, P., ed., Proceedings of the 7th International Conference on Coastal Dynamics: Arcachon, France, June 2013, paper 68, p. 749-758.

Gulf of Alaska Coastal Communities Coalition, 2003, Focus on fisheries market information-Community spotlight on the Chigniks: Anchorage, AK, Gulf of Alaska Coastal Communities Coalition, "The Gulf Channel Marker" newsletter, issue 3, $17 \mathrm{p}$.

Gusman, A.R., Tanioka, Y., Matsumoto, H., and Iwasaki, S.I., 2009, Analysis of the tsunami generated by the great 1977 Sumba earthquake that occurred in Indonesia: Bulletin of the Seismological Society of America, v. 99, no. 4, p. 2,169-2,179. http://dx.doi.org/10.1785/0120080324

Horrillo, J., Grilli, S.T., Nicolsky, Dmitry, Volker, R., and Zhang, J., 2015, Performance benchmarking tsunami models for NTHMP's inundation mapping activities. Pure and Applied Geophysics, v. 172, no. 3-4, http://dx.doi. org/10.1007/s00024-014-0891-y

Johnson, J.M., and Satake, Kenji, 1997, Estimation of seismic moment and slip distribution of the April 1, 1946, Aleutian tsunami earthquake: Journal of Geophysical Research, v. 102, no. B6, p. 11,765-11,774. http://dx.doi. org/10.1029/97JB00274

Kanamori, Hiroo, 1971, Seismological evidence for a lithospheric normal faulting-The Sanriku earthquake of 1933: Physics of the Earth and Planetary Interiors, v. 4, no. 4, p. 289-300. http://dx.doi.org/10.1016/00319201(71)90013-6

Kirby, Stephen, Scholl, David, von Huene, Roland, and Wells, Ray, 2013, Alaska earthquake source for the SAFRR tsunami scenario, chapter B, in Ross, S.L., and Jones, L.M., eds., The SAFRR (Science Application for Risk Reduction) Tsunami Scenario: U.S. Geological Survey Open-File Report 2013-1170, 40 p. http://pubs.usgs.gov/ of $/ 2013 / 1170 / \mathrm{b} /$

Kirby, J.T., Wei, Ge, Chen, Qin, Kennedy, A.B., and Dalrymple, R.A., 1998, FUNWAVE 1.0-Fully nonlinear Boussinesq wave model documentation and user's manual: Newark, DE, University of Delaware, Center for Applied Coastal Research, Department of Civil Engineering, Research Report No. CACR-98-06, 70 p.

Lander, J.F., 1996, Tsunamis affecting Alaska, 1737-1996: Boulder, CO, National Oceanic and Atmospheric Administration, National Geophysical Data Center (NGDC), Key to Geophysical Research Documentation, v. 31,155 p.
Leica Geosystems AG, 2002, GPS user manual, version 4: Heerbrugg, Switzerland, Leica Geosystems AG, 62 p.

Lynett, P.J., Wu, Tso-Ren, and Liu, Philip L.-F., 2002, Modeling wave runup with depth-integrated equations: Coastal Engineering, v. 46, no. 2, p. 89-107.http://dx.doi. org/10.1016/S0378-3839(02)00043-1

Miller, J.J., von Huene, Roland, and Ryan, H.F., 2014, The 1946 Unimak tsunami earthquake area-Revised tectonic structure in reprocessed seismic images and a suspect near-field tsunami source: U.S. Geological Survey OpenFile Report 2014-1024, 19 p. http://dx.doi.org/10.3133/ ofr20141024

National Centers for Environmental Information (NCEI/ WDS), in progress, Global historical tsunami database at NCEI, $2100 \mathrm{BC}$ to present (interactive map): National Centers for Environmental Information, NOAA, http:// dx.doi.org/10.7289/V5PN93H7

National Tsunami Hazard Mapping Program (NTHMP), 2010, Guidelines and best practices for tsunami inundation modeling for evacuation planning: National Oceanic and Atmospheric Administration (NOAA), NTHMP Mapping \& Modeling Subcommittee.

2012, Proceedings and results of the 2011 NTHMP Model Benchmarking Workshop: Boulder, CO, U.S. Department of Commerce/NOAA/NTHMP, NOAA Special Report, 436 p. http://nthmp.tsunami.gov

Nicolsky, D.J., Suleimani, E.N., Combellick, R.A., and Hansen, R.A., 2011a, Tsunami inundation maps of Whittier and western Passage Canal, Alaska: Alaska Division of Geological \& Geophysical Surveys Report of Investigation 2011-7, 65 p. http://dx.doi. org/10.14509/23244

Nicolsky, D.J., Suleimani, E.N., Freymueller, J.T., and Koehler, R.D., in press, Tsunami inundation maps of the city of Sand Point, Alaska: Alaska Division of Geological $\&$ Geophysical Surveys.

Nicolsky, D.J., Suleimani, E.N., Freymueller, J.T., and Koehler, R.D., 2015, Tsunami inundation maps of Fox Islands communities, including Dutch Harbor and Akutan, Alaska: Alaska Division of Geological \& Geophysical Surveys Report of Investigation 2015-5, 67 p., 2 sheets, scale 1:12,500. http://dx.doi.org/10.14509/29414

Nicolsky, D.J., Suleimani, E.N., Haeussler, P.J., Ryan, H.F., Koehler, R.D., Combellick, R.A., and Hansen, R.A., 2013, Tsunami inundation maps of Port Valdez, Alaska: Alaska Division of Geological \& Geophysical Surveys Report of Investigation 2013-1, 77 p., 1 sheet, scale 1:12,500.http://dx.doi.org/10.14509/25055

Nicolsky, D.J., Suleimani, E.N., and Hansen, R.A., 2011b, Validation and verification of a numerical model for tsunami propagation and runup: Pure and Applied Geophysics, v. 168, p. 1,199-1,222, http://dx.doi. org/10.1007/s00024-010-0231-9

Nicolsky, D.J., Suleimani, E.N., and Koehler, R.D., 2014, Tsunami inundation maps of Cordova and Tatitlek, Alaska: Alaska Division of Geological \& Geophysical Surveys Report of Investigation 2014-1, 49 p. http:// dx.doi.org/10.14509/27241 
Nwogu, Okey, 1993, Alternative form of Boussinesq equations for nearshore wave propagation: Journal of Waterway, Port, Coastal, and Ocean Engineering, v. 119 , no. 6 , p. $618-638$. http://dx.doi.org/10.1061/ (ASCE)0733-950X(1993)119:6(618)

Okada, Yoshimitsu, 1985, Surface deformation due to shear and tensile faults in a half-space: Bulletin of the Seismological Society of America, v. 75, no. 4, p. $1,135-1,154$.

Ross, S.L., Jones, L.M., Miller, Kevin, P., K.A., Wein, A., Wilson, Ri.I., Bahng, B., Barberopoulou, A., Borrero, J.C., Brosnan, D.M., Bwarie, J.T., Geist, E.L., Johnson, L.A., Kirby, S.H., Knight, W.R., Long, K., Lynett, P., Mortensen, C.E., Nicolsky, D.J., Perry, S.C., Plumlee, G.S., Real, C.R., Ryan, K., Suleimani, E., Thio, H., Titov, V.V., Whitmore, P.M. and Wood, N.J., 2013, SAFRR (Science Application for Risk Reduction) Tsunami Scenario-Chapter A, Executive Summary and Introduction, in Ross, S.L., and Jones, L.M., eds., The SAFRR Tsunami Scenario: U.S. Geological Survey Open-File Report 2013-1170, p. 1-17. http://pubs.usgs. gov/of/2013/1170/

Ryan, H.F., von Huene, Roland, Scholl, Dave, and Kirby, Steve, 2012, Tsunami hazards to U.S. coasts from giant earthquakes in Alaska: Eos, Transactions, American Geophysical Union, v. 93, no. 19, p. 185-186. http:// dx.doi.org/10.1029/2012EO190001

Soloviev, S.L., 1968, The Sanak Kodiak Island tsunami of 1788 [in Russian]: Moscow, Nauka, The Tsunami Problem, p. 232-237. [English translation in Science of Tsunami Hazards, v. 8, no. 1, p. 34-38, 1990.] http:// library.lanl.gov/tsunami/00394733.pdf

Stauder, William, 1968, Mechanism of the Rat Island earthquake sequence of February 4, 1965, with relation to island arcs and sea-floor spreading: Journal of Geophysical Research, v. 73 , no. 12 , p. 3,847-3,858. http://dx.doi.org/10.1029/JB073i012p03847

Suleimani, E.N., Nicolsky, D.J., and Koehler, R.D., 2013, Tsunami inundation maps of Sitka, Alaska: Alaska Division of Geological \& Geophysical Surveys Report of Investigation 2013-3, 76 p., 1 sheet, scale 1:250,000. http://dx.doi.org/10.14509/26671
Suleimani, E.N., Nicolsky, D.J., and Koehler, R.D., 2015, Tsunami inundation maps of Elfin Cove, Gustavus, and Hoonah, Alaska: Alaska Division of Geological \& Geophysical Surveys Report of Investigation 2015-1, 79 p. http://dx.doi.org/10.14509/29404

Suleimani, E.N., Nicolsky, D.J., West, D.A., Combellick, R.A., and Hansen, R.A., 2010, Tsunami inundation maps of Seward and northern Resurrection Bay, Alaska: Alaska Division of Geological \& Geophysical Surveys Report of Investigation 2010-1, 47 p., 3 sheets, scale 1:12,500. http://dx.doi.org/10.14509/21001

Sykes, L.R., 1971, Aftershock zones of great earthquakes, seismicity gaps, and earthquake prediction for Alaska and the Aleutians: Journal of Geophysical Research, v. 76, no. 32, p. 8,021-8,041. http://dx.doi.org/10.1029/ JB076i032p08021

Synolakis, C.E., Bernard, E.N., Titov, V.V., Kânoğlu, U., and González, F.I., 2007, Standards, criteria, and procedures for NOAA evaluation of tsunami numerical models: Seattle, NOAA/Pacific Marine Environmental Laboratory, Technical Memorandum OAR PMEL-135, $55 \mathrm{p}$.

Tichelaar, B.W., and Ruff, L.J., 1993, Depth of seismic coupling along subduction zones: Journal of Geophysical Research, v. 98, p. 2,017-2,037. http://dx.doi. org/10.1029/92JB02045

U.S. Geological Survey National Earthquake Information Center, 2015, Event page for 2014 M $7.919 \mathrm{~km} \mathrm{SE}$ of Little Sitkin Island, Alaska, quake: U.S. Geological Survey online earthquake catalog, http://earthquake.usgs. gov/earthquakes/eventpage/usc000rki5. Last accessed December 7, 2015.

Wesson, R.L., Boyd, O.S., Mueller, C.S., and Frankel, A.D., 2008, Challenges in making a seismic hazard map for Alaska and the Aleutians, in Freymueller, J.T., Haeussler, P.J., Wesson, R., and Ekström, G., eds., Active Tectonics and Seismic Potential of Alaska: Washington, D.C., American Geophysical Union, Geophysical Monograph v. 179 , p. $385-397$. 


\section{APPENDIX A}

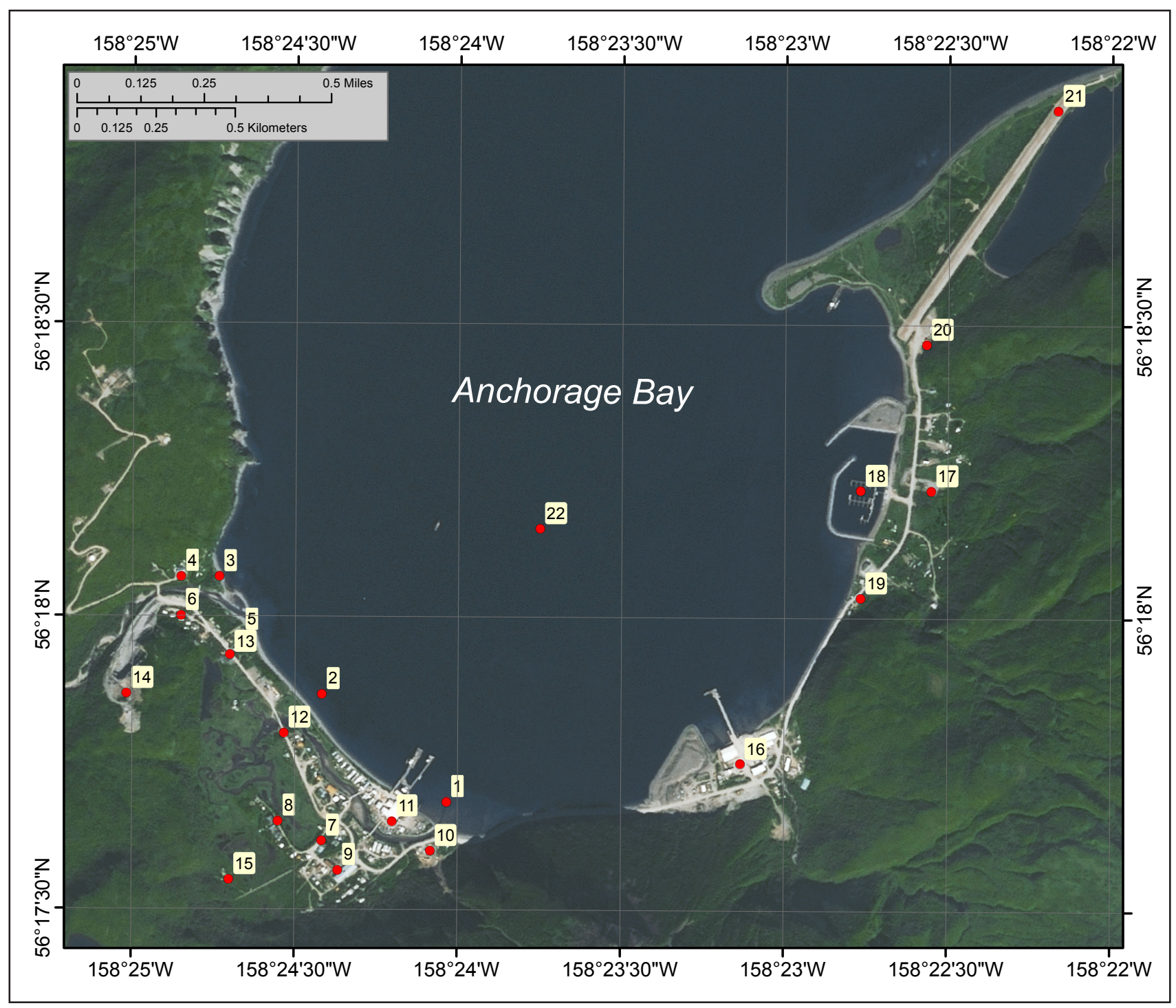

Appendix A-1. Locations of time series points in Anchorage Bay and the city of Chignik. The longitude and latitude locations of the time series points are listed in Table A-1. 


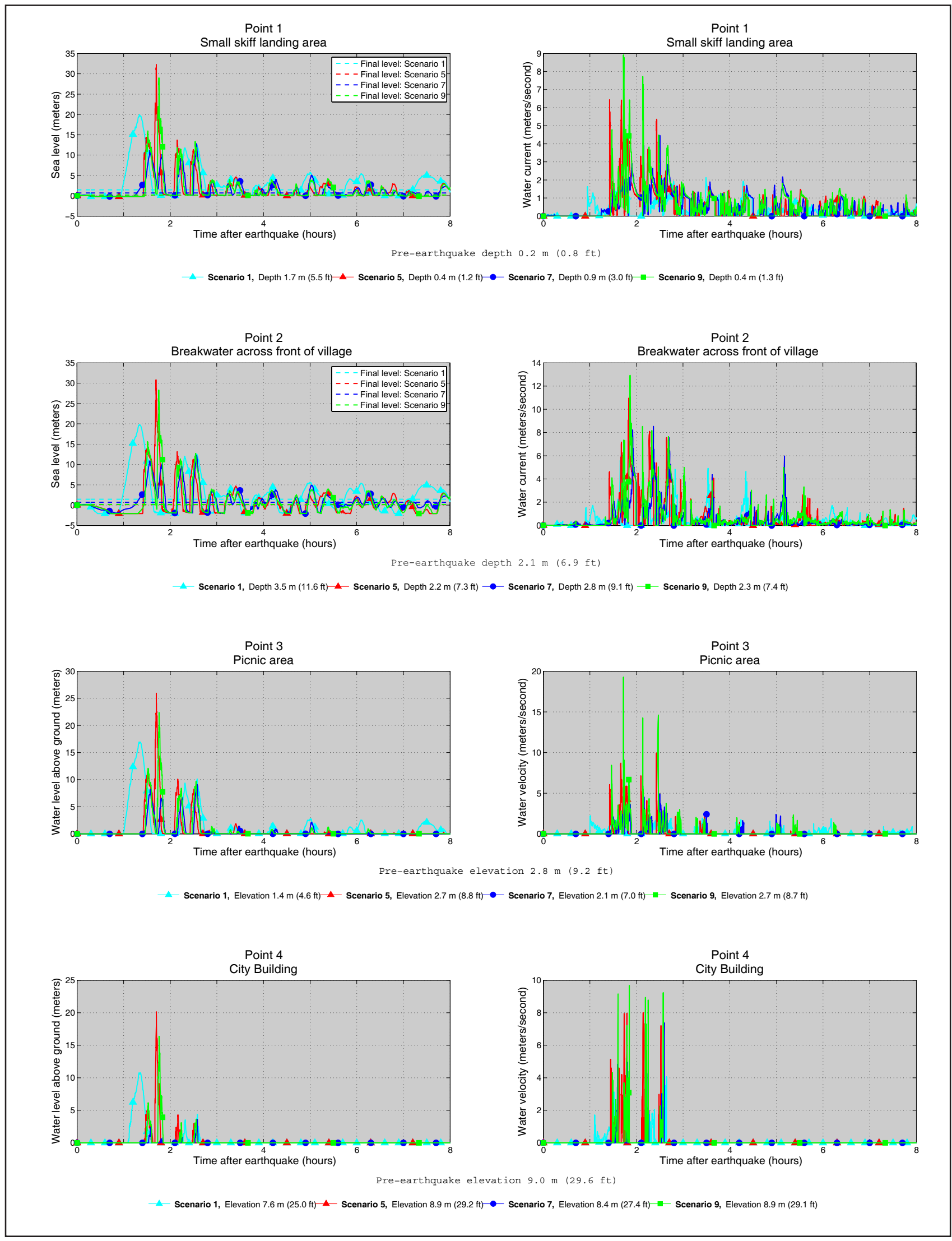

Appendix A-2. Time series of water level (left) and velocity (right) at selected locations in Anchorage Bay for scenarios 1, 5, 7, and 9. The pre-earthquake elevation/depth with respect to the MHHW is stated for each location. The post-earthquake elevation/depth corresponding to the MHHW datum is also listed for each scenario. For offshore locations, to show the height of an arriving tsunami, the vertical datum is such that zero corresponds to the pre-earthquake sea level. The dashed lines show the water level after the tsunami. 

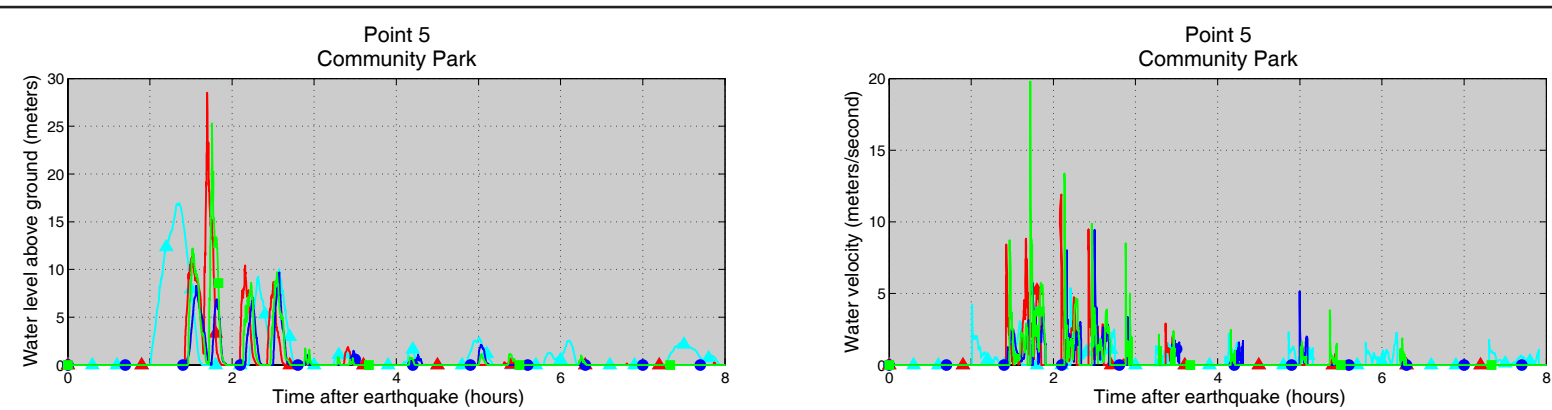

Pre-earthquake elevation $2.8 \mathrm{~m}(9.3 \mathrm{ft})$

- Scenario 1, Elevation $1.4 \mathrm{~m}(4.6 \mathrm{ft}) \_$Scenario 5, Elevation $2.7 \mathrm{~m}(8.8 \mathrm{ft})-$ Scenario 7, Elevation $2.2 \mathrm{~m}(7.1 \mathrm{ft})-$ - Scenario 9, Elevation $2.7 \mathrm{~m}(8.8 \mathrm{ft})$
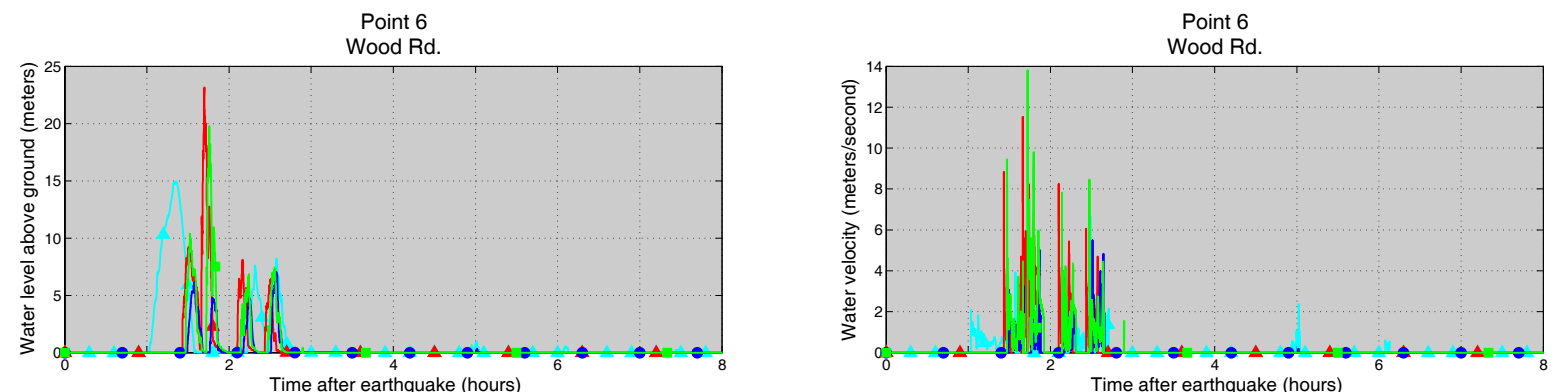

Pre-earthquake elevation $4.9 \mathrm{~m}(16.0 \mathrm{ft})$

- Scenario 1, Elevation $3.5 \mathrm{~m}(11.3 \mathrm{ft})-$ Scenario 5 , Elevation $4.7 \mathrm{~m}(15.5 \mathrm{ft})-$ Scenario 7, Elevation $4.2 \mathrm{~m}(13.8 \mathrm{ft})-$ - Scenario 9, Elevation $4.7 \mathrm{~m}(15.5 \mathrm{ft})$
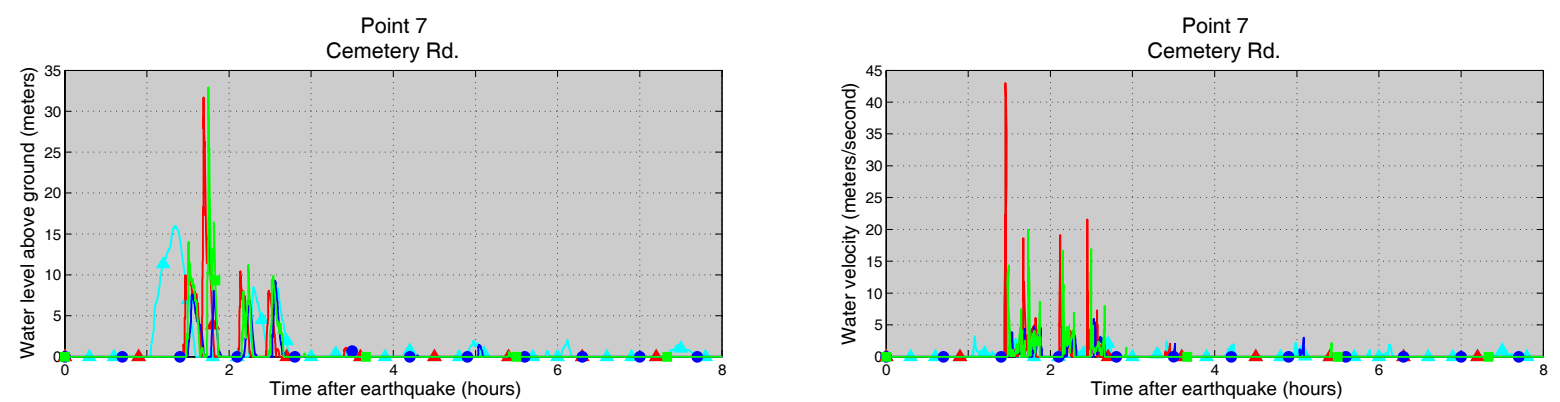

Pre-earthquake elevation $3.9 \mathrm{~m}(12.8 \mathrm{ft})$

- Scenario 1, Elevation $2.4 \mathrm{~m}(8.0 \mathrm{ft}) \longrightarrow$ Scenario 5, Elevation $3.7 \mathrm{~m}(12.3 \mathrm{ft}) \longrightarrow$ Scenario 7 , Elevation $3.2 \mathrm{~m}(10.5 \mathrm{ft})-$ Scenario 9 , Elevation $3.7 \mathrm{~m}(12.2 \mathrm{ft})$
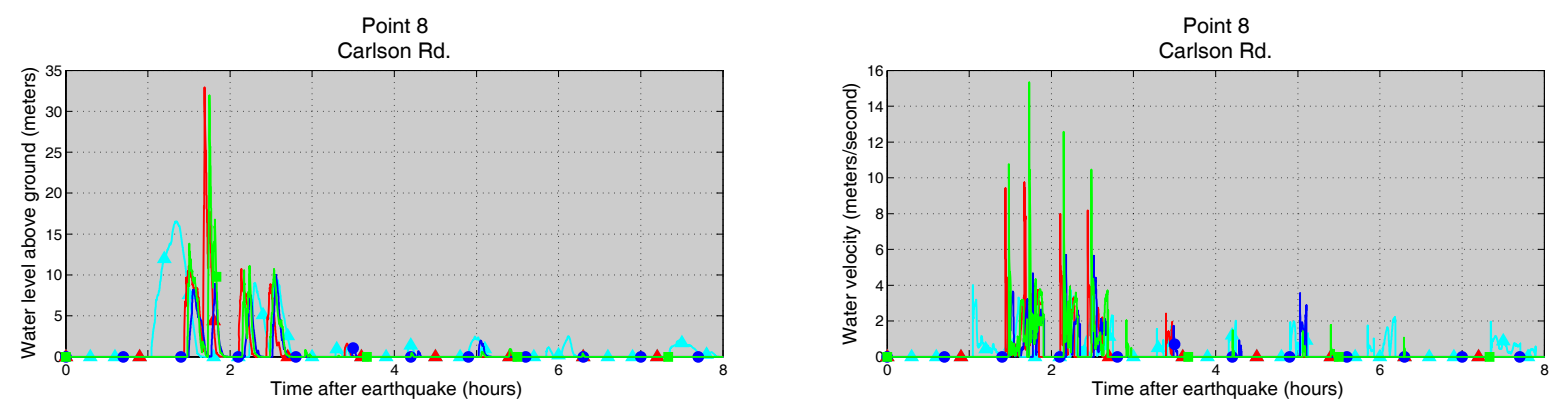

Pre-earthquake elevation $3.3 \mathrm{~m}(10.8 \mathrm{ft})$

- Scenario 1, Elevation $1.9 \mathrm{~m}(6.1 \mathrm{ft})-$ Scenario 5 , Elevation $3.2 \mathrm{~m}(10.4 \mathrm{ft})-$ Scenario 7 , Elevation $2.6 \mathrm{~m}(8.6 \mathrm{ft}) \rightarrow$ Scenario 9 , Elevation $3.1 \mathrm{~m}(10.3 \mathrm{ft})$

Appendix A-2, continued. Time series of water level (left) and velocity (right) at selected locations in Anchorage Bay for scenarios 1, 5, 7, and 9. The pre-earthquake elevation/depth with respect to the MHHW is stated for each location. The post-earthquake elevation/depth corresponding to the MHHW datum is also listed for each scenario. For offshore locations, to show the height of an arriving tsunami, the vertical datum is such that zero corresponds to the pre-earthquake sea level. The dashed lines show the water level after the tsunami. 

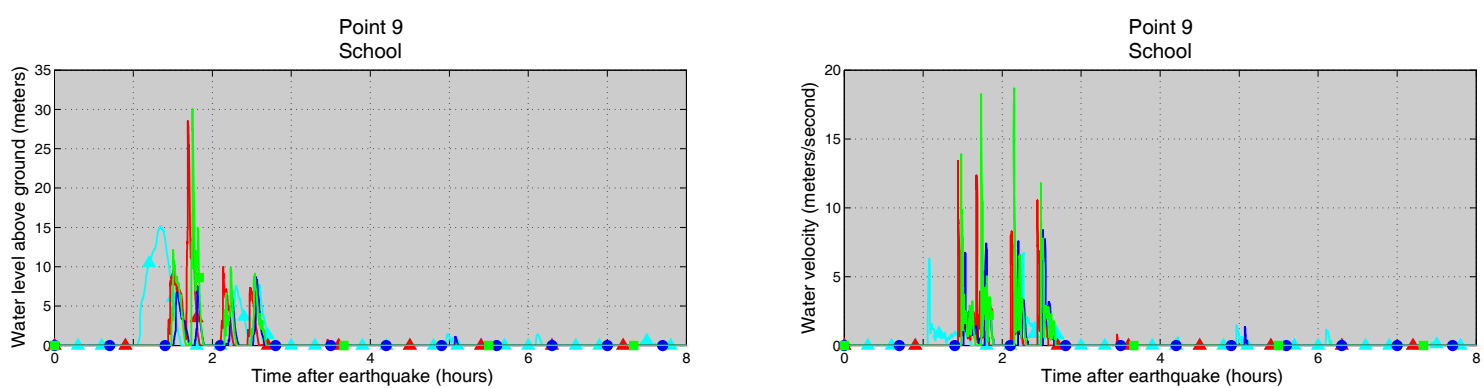

Pre-earthquake elevation $4.7 \mathrm{~m}(15.5 \mathrm{ft})$

$\triangle$ Scenario 1, Elevation $3.3 \mathrm{~m}(10.8 \mathrm{ft}) \backsim$ Scenario 5, Elevation $4.6 \mathrm{~m}(15.1 \mathrm{ft})-$ Scenario 7 , Elevation $4.1 \mathrm{~m}(13.3 \mathrm{ft})-\mathrm{m}-$ Scenario 9 , Elevation $4.6 \mathrm{~m}(15.0 \mathrm{ft})$
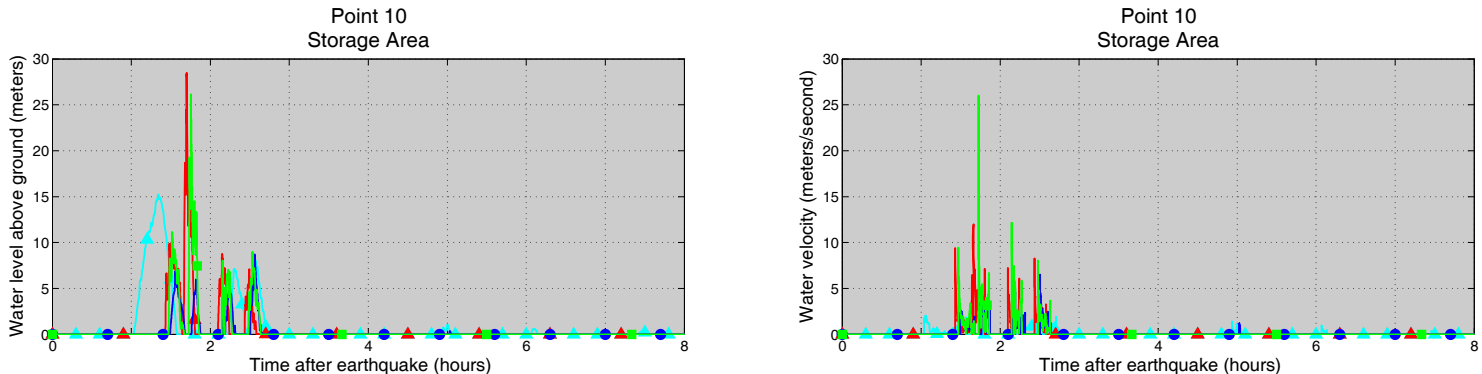

Pre-earthquake elevation $4.8 \mathrm{~m}(15.8 \mathrm{ft})$

- Scenario 1, Elevation $3.4 \mathrm{~m}(11.0 \mathrm{ft})-$ Scenario 5, Elevation $4.7 \mathrm{~m}(15.3 \mathrm{ft})-$ Scenario 7, Elevation $4.1 \mathrm{~m}(13.6 \mathrm{ft})-$ - Scenario 9 , Elevation $4.7 \mathrm{~m}(15.3 \mathrm{ft})$
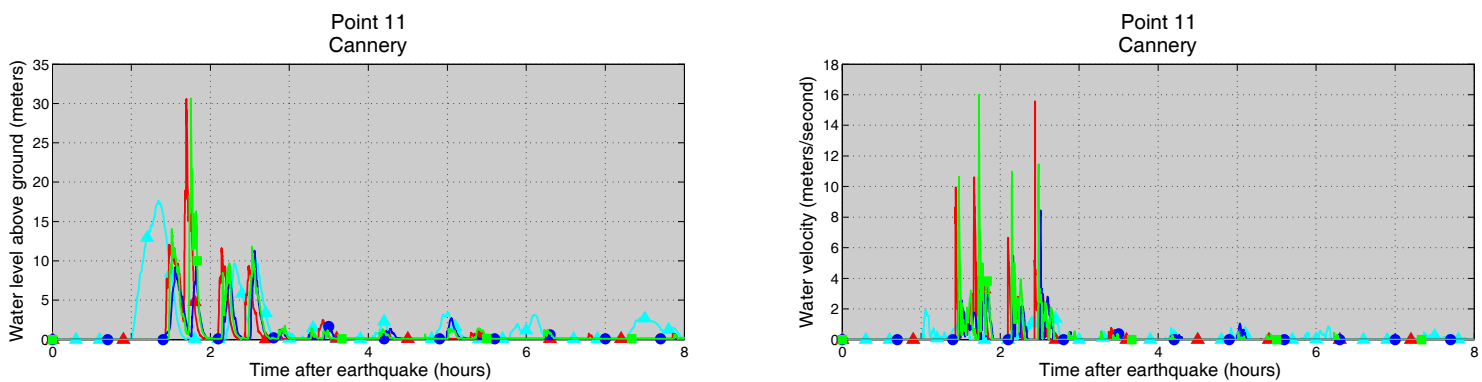

Pre-earthquake elevation $2.3 \mathrm{~m}(7.5 \mathrm{ft})$

$\triangle$ Scenario 1, Elevation $0.8 \mathrm{~m}(2.8 \mathrm{ft})-$ Scenario 5, Elevation $2.2 \mathrm{~m}(7.1 \mathrm{ft})-$ Scenario 7, Elevation $1.6 \mathrm{~m}(5.3 \mathrm{ft})-$ - Scenario 9, Elevation $2.1 \mathrm{~m}(7.0 \mathrm{ft})$
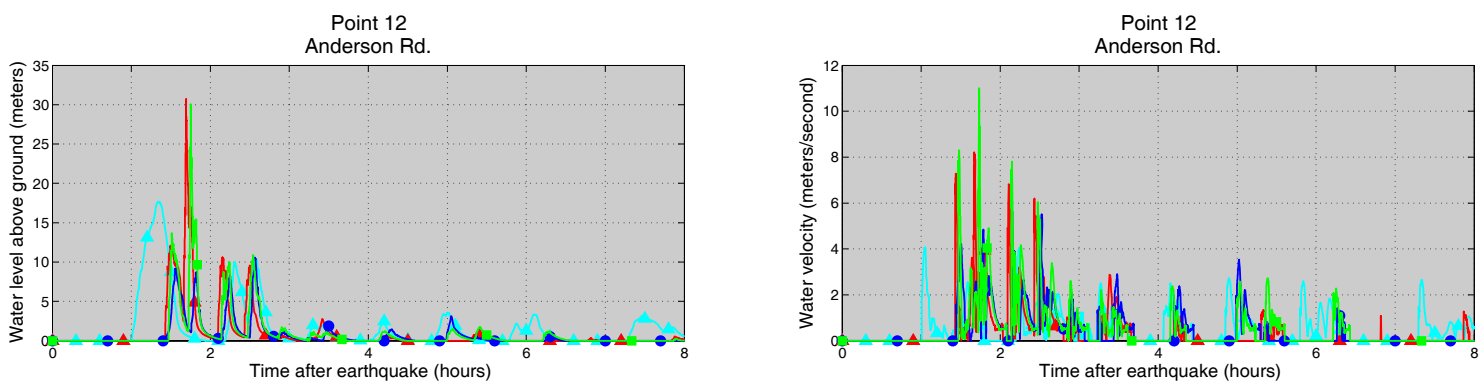

Pre-earthquake elevation $2.1 \mathrm{~m}(6.9 \mathrm{ft})$

- Scenario 1, Elevation $0.7 \mathrm{~m}(2.2 \mathrm{ft})-$ Scenario 5, Elevation $2.0 \mathrm{~m}(6.4 \mathrm{ft})-$ Scenario 7, Elevation $1.4 \mathrm{~m}(4.7 \mathrm{ft})-\mathrm{m}$ - Scenario 9, Elevation $1.9 \mathrm{~m}(6.4 \mathrm{ft})$

Appendix A-2, continued. Time series of water level (left) and velocity (right) at selected locations in Anchorage Bay for scenarios 1, 5, 7, and 9. The pre-earthquake elevation/depth with respect to the MHHW is stated for each location. The post-earthquake elevation/depth corresponding to the MHHW datum is also listed for each scenario. For offshore locations, to show the height of an arriving tsunami, the vertical datum is such that zero corresponds to the pre-earthquake sea level. The dashed lines show the water level after the tsunami. 

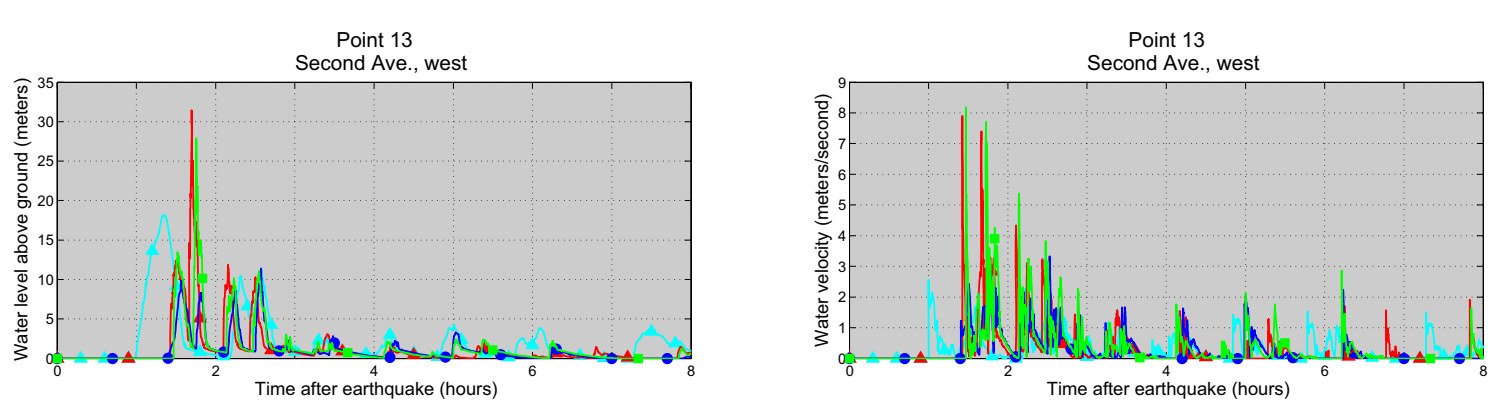

Pre-earthquake elevation $1.6 \mathrm{~m}(5.2 \mathrm{ft})$

$\triangle$ Scenario 1, Elevation $0.2 \mathrm{~m}(0.6 \mathrm{ft})-$ Scenario 5, Elevation $1.5 \mathrm{~m}(4.8 \mathrm{ft})-$ Scenario 7, Elevation $0.9 \mathrm{~m}(3.1 \mathrm{ft})-$ - Scenario 9, Elevation $1.4 \mathrm{~m}(4.7 \mathrm{ft})$
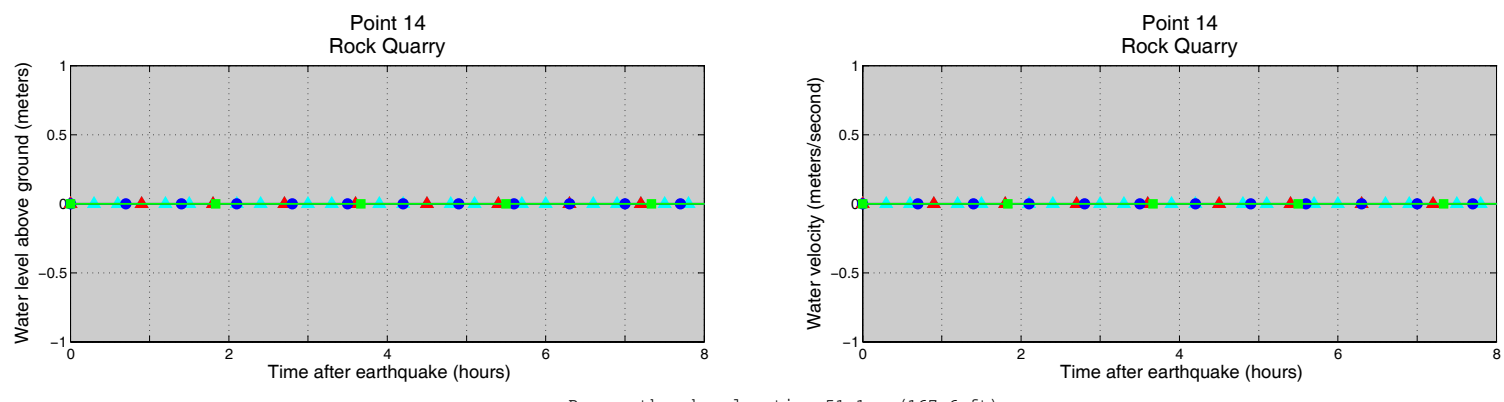

Pre-earthquake elevation $51.1 \mathrm{~m}(167.6 \mathrm{ft})$

$\triangle$ Scenario 1, Elevation $49.7 \mathrm{~m}(162.9 \mathrm{ft})-$ Scenario 5 , Elevation $51.0 \mathrm{~m}(167.1 \mathrm{ft})-$ Scenario 7, Elevation $50.4 \mathrm{~m}(165.4 \mathrm{ft})-$ Scenario 9 , Elevation $51.0 \mathrm{~m}(167.1 \mathrm{ft})$
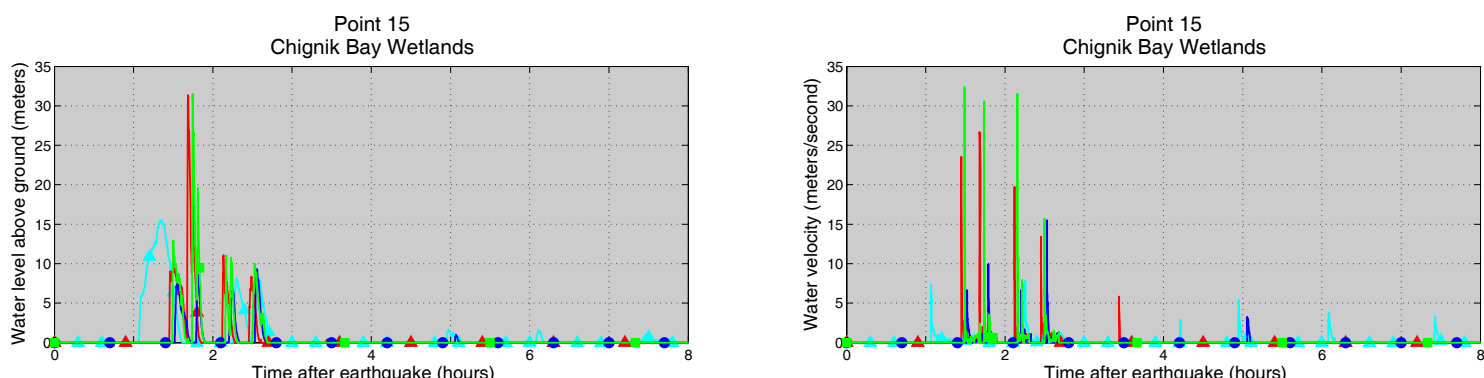

Pre-earthquake elevation $4.5 \mathrm{~m}(14.7 \mathrm{ft})$

$\triangle$ Scenario 1, Elevation $3.0 \mathrm{~m}(9.9 \mathrm{ft})-$ Scenario 5, Elevation $4.3 \mathrm{~m}(14.2 \mathrm{ft})-$ Scenario 7 , Elevation $3.8 \mathrm{~m}(12.4 \mathrm{ft})-\mathrm{m}-$ Scenario 9 , Elevation $4.3 \mathrm{~m}(14.1 \mathrm{ft})$
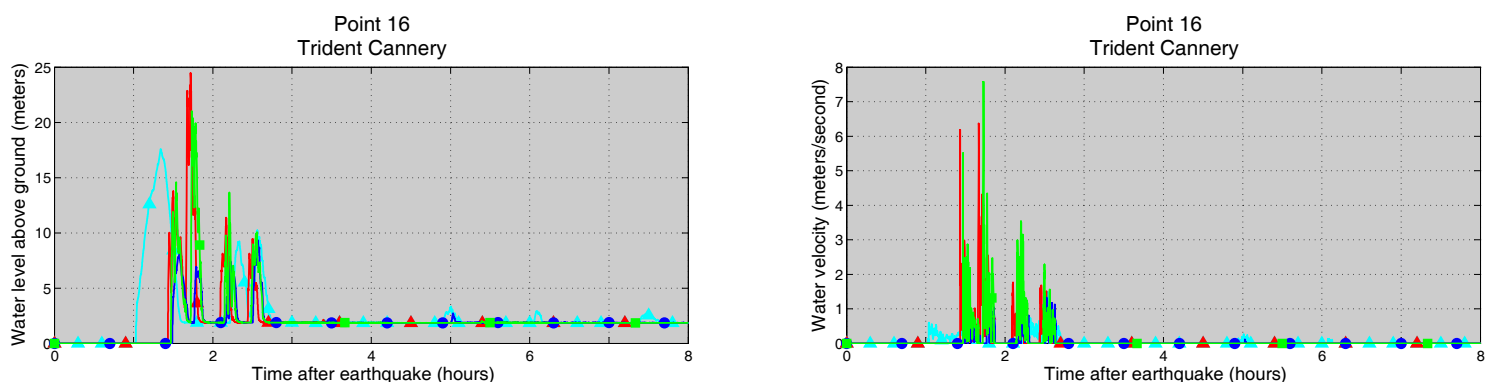

Pre-earthquake elevation $2.5 \mathrm{~m}(8.2 \mathrm{ft})$

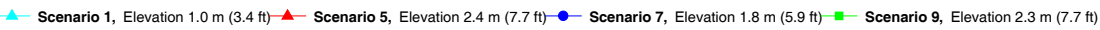

Appendix A-2, continued. Time series of water level (left) and velocity (right) at selected locations in Anchorage Bay for scenarios 1, 5, 7, and 9. The pre-earthquake elevation/depth with respect to the MHHW is stated for each location. The post-earthquake elevation/depth corresponding to the MHHW datum is also listed for each scenario. For offshore locations, to show the height of an arriving tsunami, the vertical datum is such that zero corresponds to the pre-earthquake sea level. The dashed lines show the water level after the tsunami. 

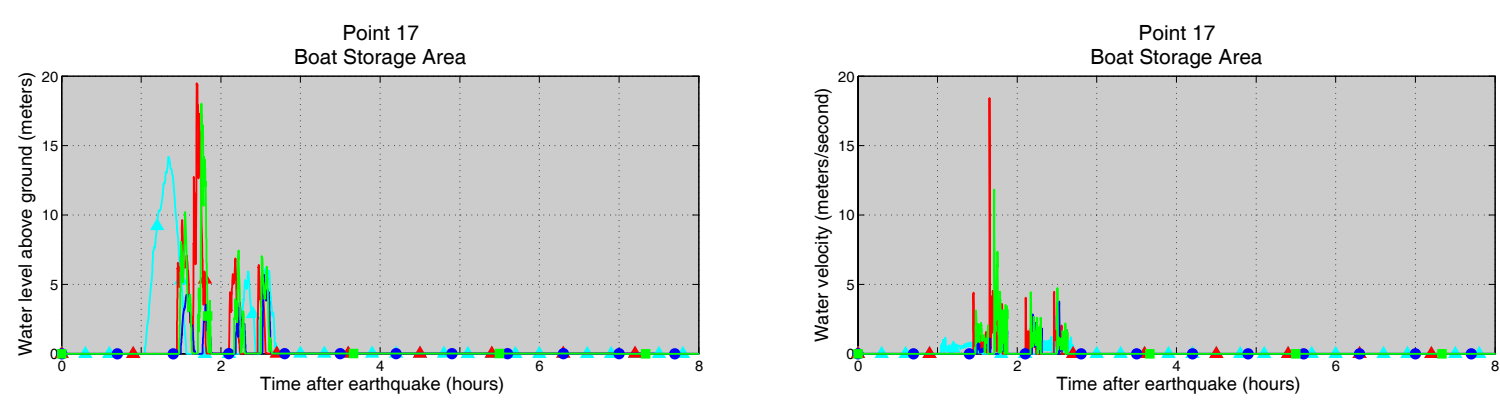

Pre-earthquake elevation $5.8 \mathrm{~m}(18.9 \mathrm{ft})$

- Scenario 1, Elevation $4.3 \mathrm{~m}(14.1 \mathrm{ft})-$ Scenario 5 , Elevation $5.6 \mathrm{~m}(18.4 \mathrm{ft})-$ Scenario 7 , Elevation $5.1 \mathrm{~m}(16.7 \mathrm{ft})-$ Scenario 9, Elevation $5.6 \mathrm{~m}(18.4 \mathrm{ft})$
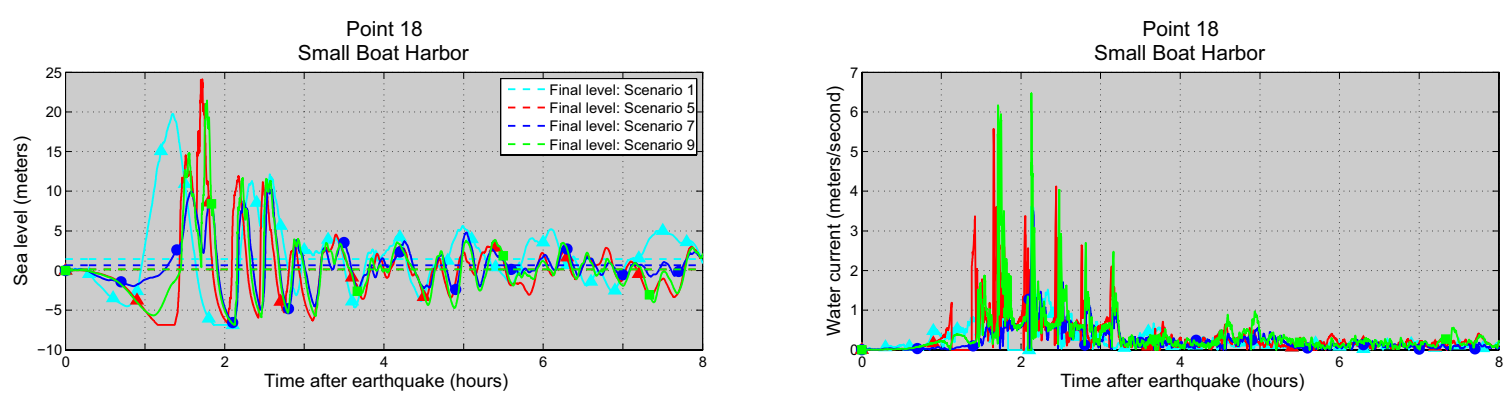

Pre-earthquake depth $6.8 \mathrm{~m}(22.5 \mathrm{ft})$

$\triangle$ Scenario 1, Depth $8.3 \mathrm{~m}(27.2 \mathrm{ft}) \backsim$ Scenario 5, Depth $7.0 \mathrm{~m}(22.9 \mathrm{ft})-$ Scenario 7 , Depth $7.5 \mathrm{~m}(24.7 \mathrm{ft}) \backsim$ - Scenario 9 , Depth $7.0 \mathrm{~m}(23.0 \mathrm{ft})$
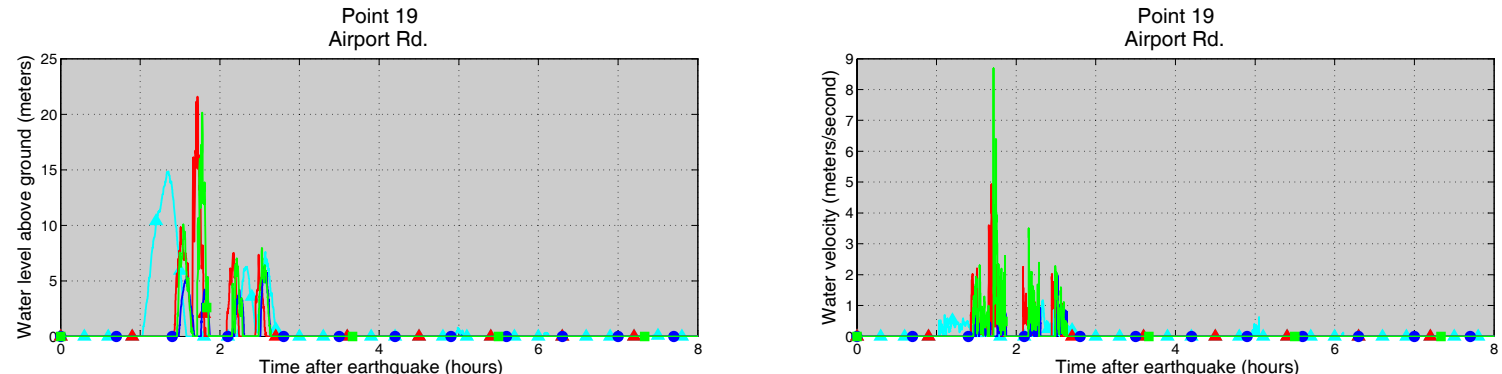

Pre-earthquake elevation $5.0 \mathrm{~m}(16.3 \mathrm{ft})$

$\triangle$ Scenario 1, Elevation $3.5 \mathrm{~m}(11.5 \mathrm{ft})-$ Scenario 5, Elevation $4.8 \mathrm{~m}(15.8 \mathrm{ft}) \bullet-$ Scenario 7 , Elevation $4.3 \mathrm{~m}(14.0 \mathrm{ft})-$ Scenario 9, Elevation $4.8 \mathrm{~m}(15.8 \mathrm{ft})$
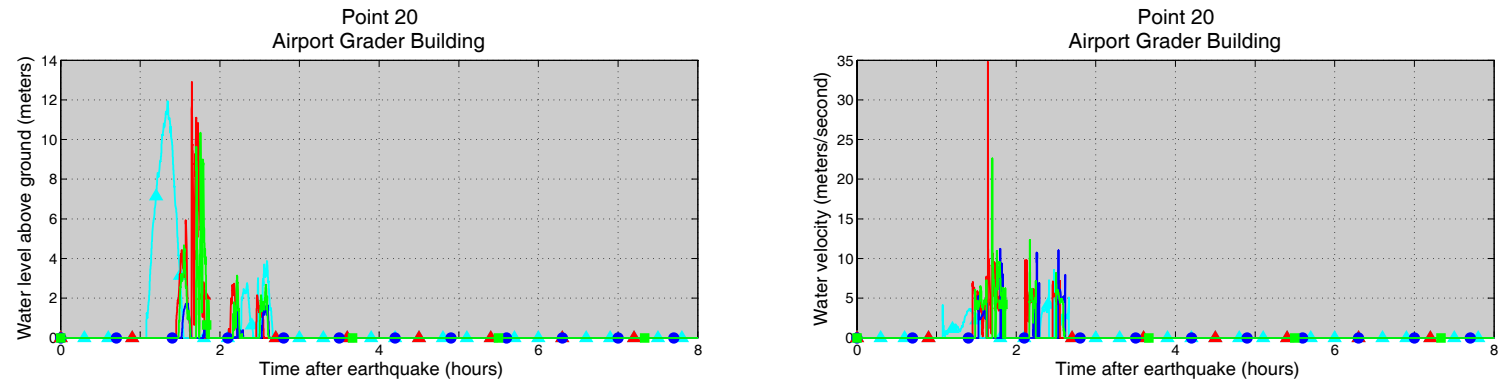

Pre-earthquake elevation $7.5 \mathrm{~m}(24.6 \mathrm{ft})$

$\triangle$ Scenario 1, Elevation $6.0 \mathrm{~m}(19.8 \mathrm{ft})-$ Scenario 5, Elevation $7.4 \mathrm{~m}(24.1 \mathrm{ft})-$ Scenario 7, Elevation $6.8 \mathrm{~m}(22.4 \mathrm{ft})-$ - Scenario 9, Elevation $7.3 \mathrm{~m}(24.1 \mathrm{ft})$

Appendix A-2, continued. Time series of water level (left) and velocity (right) at selected locations in Anchorage Bay for scenarios 1, 5, 7, and 9. The pre-earthquake elevation/depth with respect to the MHHW is stated for each location. The post-earthquake elevation/depth corresponding to the MHHW datum is also listed for each scenario. For offshore locations, to show the height of an arriving tsunami, the vertical datum is such that zero corresponds to the pre-earthquake sea level. The dashed lines show the water level after the tsunami. 


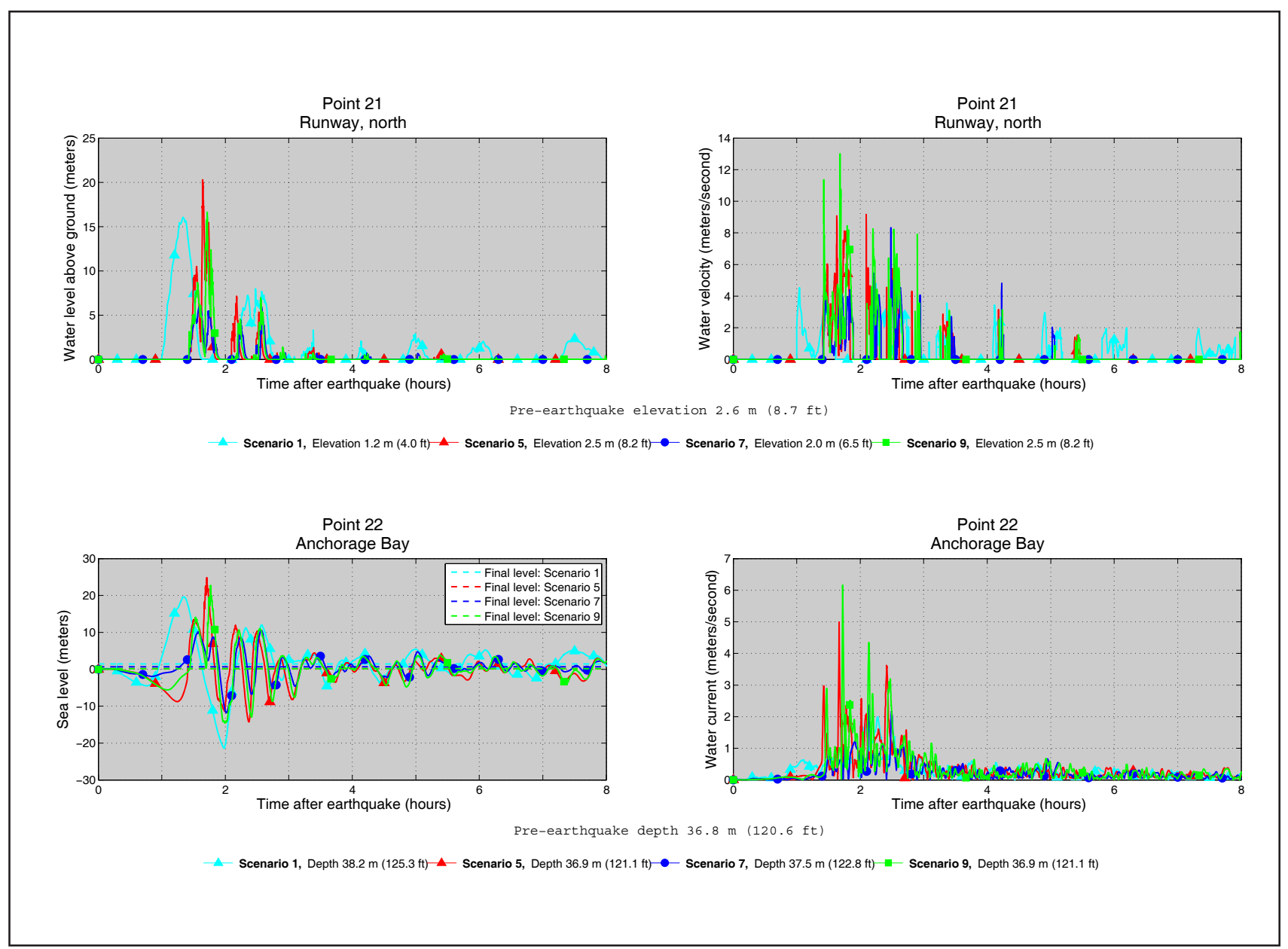

Appendix A-2, continued. Time series of water level (left) and velocity (right) at selected locations in Anchorage Bay for scenarios 1, 5, 7, and 9. The pre-earthquake elevation/depth with respect to the MHHW is stated for each location. The post-earthquake elevation/depth corresponding to the MHHW datum is also listed for each scenario. For offshore locations, to show the height of an arriving tsunami, the vertical datum is such that zero corresponds to the pre-earthquake sea level. The dashed lines show the water level after the tsunami. 
$\tilde{0} \mathrm{~g} \cdot \underline{2}$

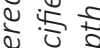

$\frac{2}{3} \frac{8}{8}$

जे

o

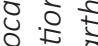

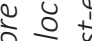

角政

o थ

के के है

웡

वे 웡

층

जิ

รั ตे

ㄷำ

\&

응

o o

ह

\& व

¿े

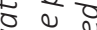

3 용

है ठ

हो ह

है ठ

है ปั

岕跑主

엉워

요

웡

당

일

जथ

空

政

ह $\sum_{\infty}$

\% 임

s 웡

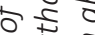

है के ई

ริ

ㅎํㅇ

$\circ$ \&

का ह

วิ है ป

造

응

ㄷํㅇำ

वे के

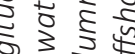

궁

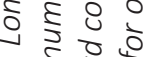

$-i$ ह.

女文

थ ह \&

एक

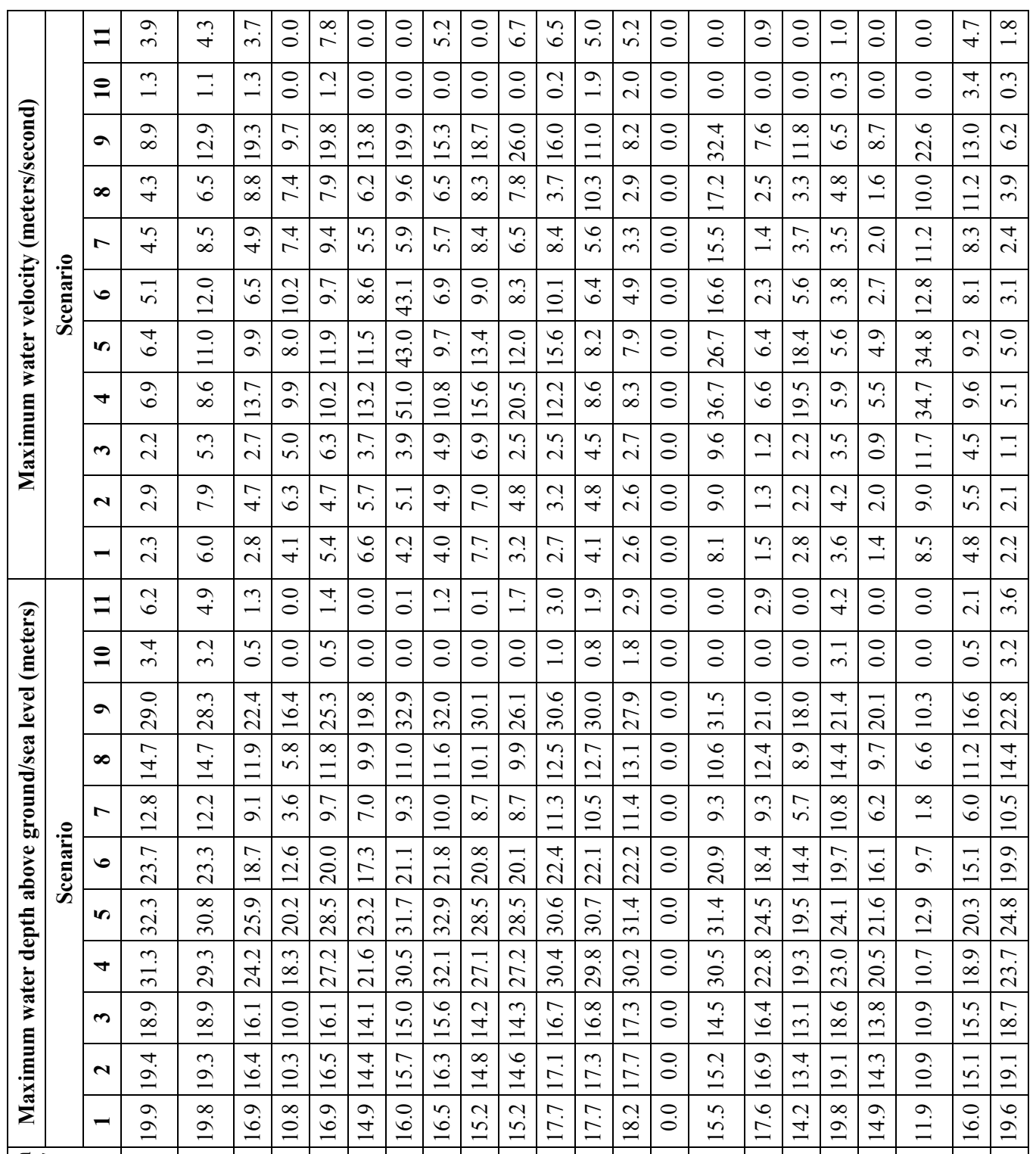

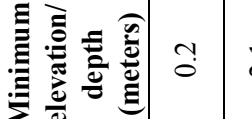

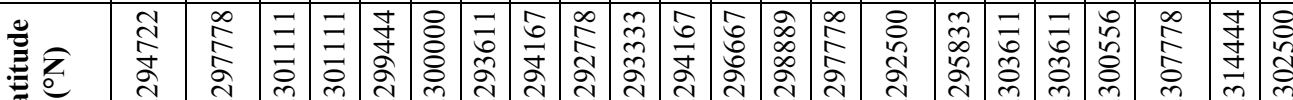

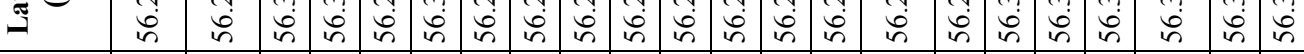

\begin{tabular}{|c|c|c|c|c|c|c|c|c|c|c|c|c|c|c|c|c|c|c|c|c|c|c|c|}
\hline 总 & $\begin{array}{l}\mathscr{0} \\
\tilde{n} \\
\hat{o} \\
\vdots \\
\infty \\
n \\
n\end{array}$ & 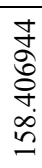 & $\stackrel{\infty}{2}$ & $\begin{array}{l}5 \\
7 \\
7 \\
2 \\
y\end{array}$ & $\begin{array}{l}\bar{y} \\
\infty \\
\infty\end{array}$ & $\begin{array}{l}7 \\
z \\
z \\
\alpha \\
x\end{array}$ & $\underline{w}$ & $\begin{array}{l}\mathfrak{z} \\
g \\
g \\
q \\
\alpha \\
v\end{array}$ & 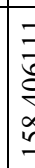 & $\frac{a}{a}$ & 4 & $\begin{array}{l}2 \\
\vdots \\
o \\
\vdots \\
\vdots \\
d \\
y\end{array}$ & is & & is & & & n & $\begin{array}{l}0 \\
n\end{array}$ & 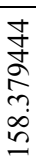 & $\begin{array}{l}\exists \\
\Xi \\
0 \\
\infty \\
\infty \\
n\end{array}$ & & $\begin{array}{l}\infty \\
\infty \\
\infty \\
2 \\
\infty \\
\infty \\
\infty \\
n\end{array}$ \\
\hline$n-0$ & 0 & 0 & $n$ & 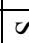 & 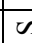 & $\sigma$ & $v$ & $\bar{v}$ & 0 & 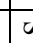 & $\bar{U}$ & & 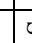 & & 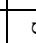 & & & $n$ & 0 & 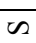 & 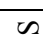 & Us & 0 \\
\hline
\end{tabular}

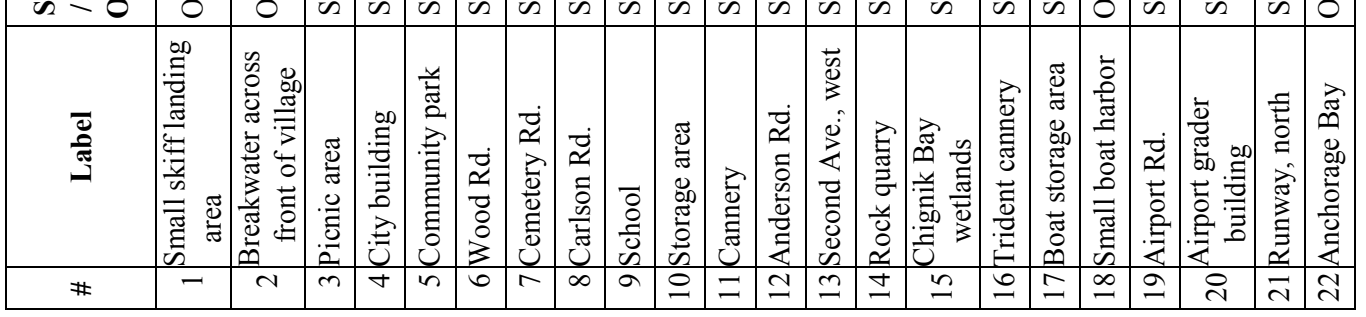




\section{APPENDIX B}

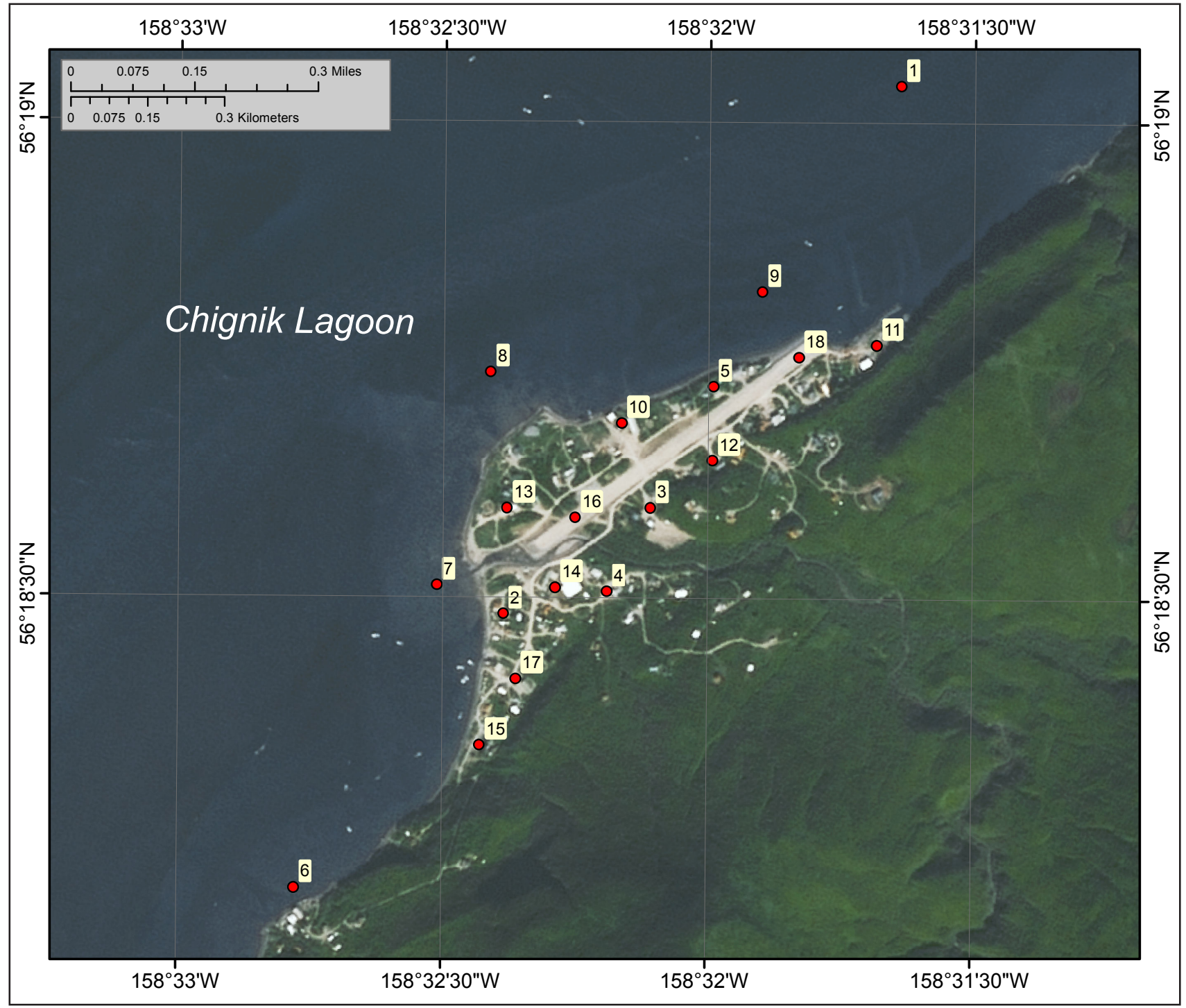

Appendix B-1. Locations of time series points in Chignik Lagoon and the village of Chignik Lagoon. The longitude and latitude locations of the time series points are listed in Table B-1. 

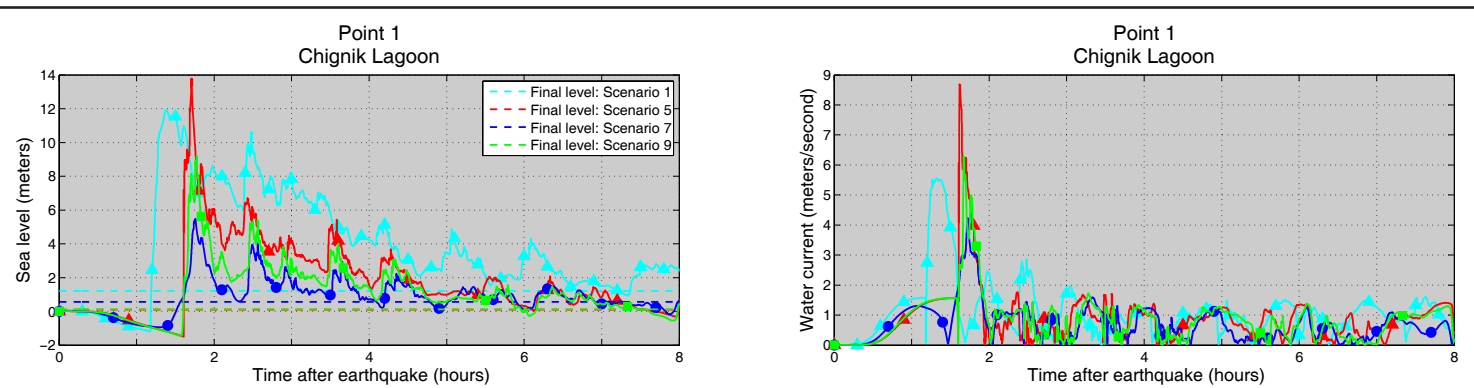

Pre-earthquake depth $12.3 \mathrm{~m}(40.2 \mathrm{ft})$

- Scenario 1, Depth $13.5 \mathrm{~m}(44.2 \mathrm{ft})-$ Scenario 5, Depth $12.4 \mathrm{~m}(40.6 \mathrm{ft}) \bullet$ Scenario 7, Depth $12.8 \mathrm{~m}(42.1 \mathrm{ft})-$ Scenario 9, Depth $12.4 \mathrm{~m}(40.6 \mathrm{ft})$
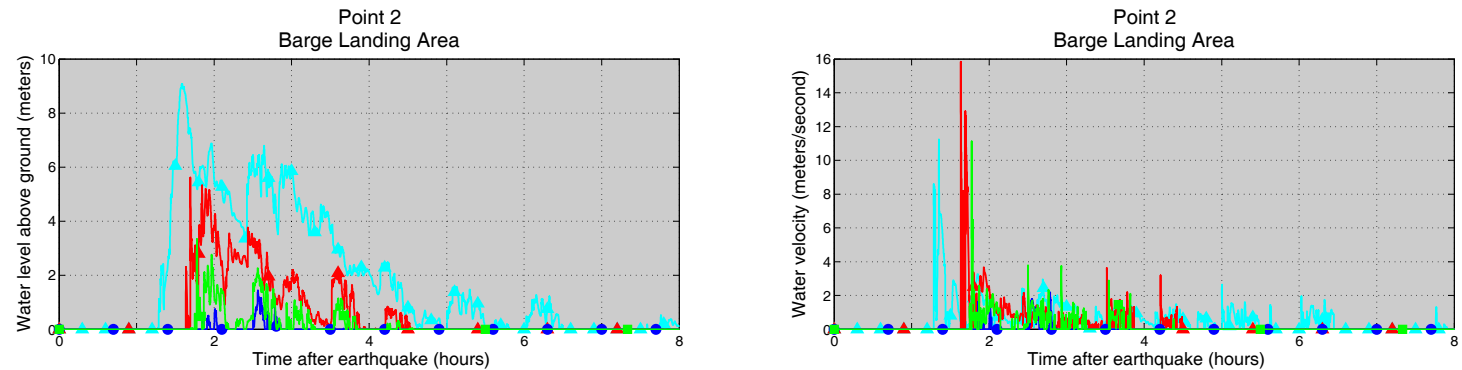

Pre-earthquake elevation $2.2 \mathrm{~m}(7.2 \mathrm{ft})$

$\triangle$ Scenario 1, Elevation $1.1 \mathrm{~m}(3.6 \mathrm{ft})-$ Scenario 5, Elevation $2.2 \mathrm{~m}(7.2 \mathrm{ft}) \bullet$ Scenario 7, Elevation $1.7 \mathrm{~m}(5.7 \mathrm{ft})-$ Scenario 9 , Elevation $2.2 \mathrm{~m}(7.2 \mathrm{ft})$
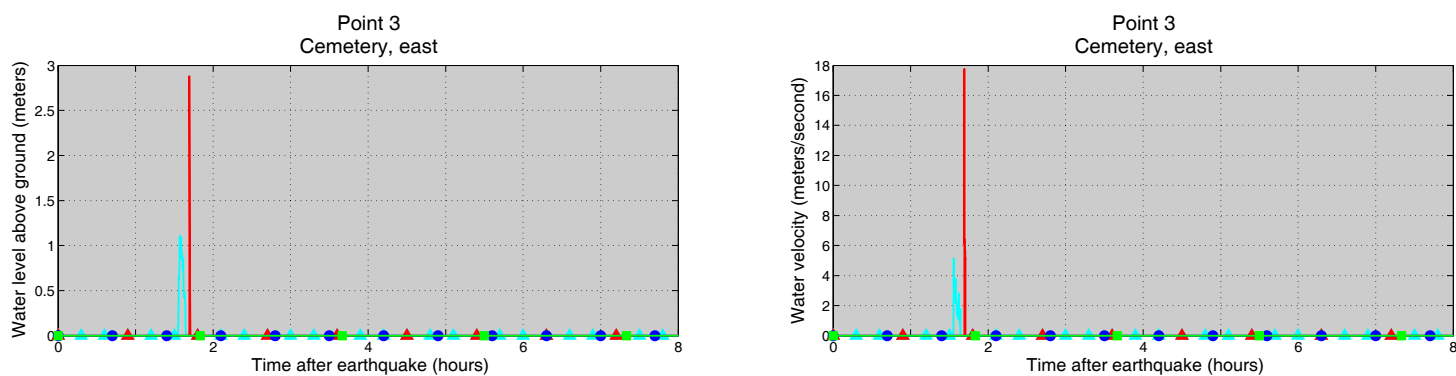

Pre-earthquake elevation $10.3 \mathrm{~m}(33.9 \mathrm{ft})$

$\triangle$ Scenario 1, Elevation $9.2 \mathrm{~m}(30.3 \mathrm{ft})-$ Scenario 5, Elevation $10.4 \mathrm{~m}(33.9 \mathrm{ft})-$ Scenario 7, Elevation $9.9 \mathrm{~m}(32.4 \mathrm{ft}) \longrightarrow$ - Scenario 9 , Elevation $10.3 \mathrm{~m}(33.9 \mathrm{ft})$

Point 4

Second St. and "A" St.

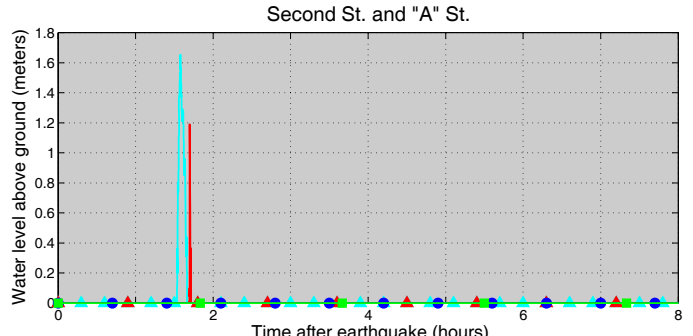

Pre-earthquake elevat
Point 4

Second St. and "A" St.

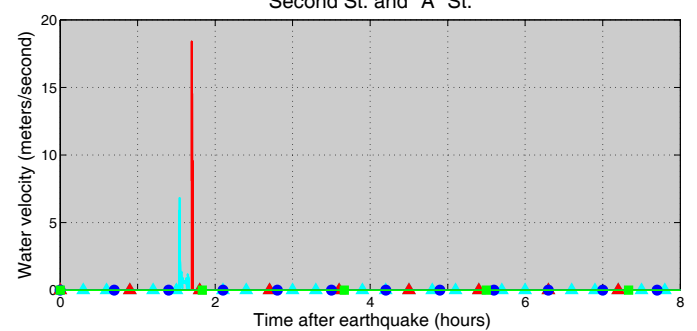

Time after earthquake (hours)

$\triangle$ Scenario 1, Elevation $8.8 \mathrm{~m}(28.9 \mathrm{ft})-$ Scenario 5, Elevation $9.9 \mathrm{~m}(32.6 \mathrm{ft})-$ Scenario 7, Elevation $9.5 \mathrm{~m}(31.1 \mathrm{ft})-$ - Scenario 9, Elevation $9.9 \mathrm{~m}(32.5 \mathrm{ft})$

Appendix B-2. Time series of water level (left) and velocity (right) at selected locations in Chignik Lagoon for scenarios 1, 5, 7, and 9. The pre-earthquake elevation/depth with respect to the MHHW is stated for each location. The post-earthquake elevation/depth corresponding to the MHHW datum is also listed for each scenario. For offshore locations, to show the height of an arriving tsunami, the vertical datum is such that zero corresponds to the pre-earthquake sea level. The dashed lines show the water level after the tsunami. 

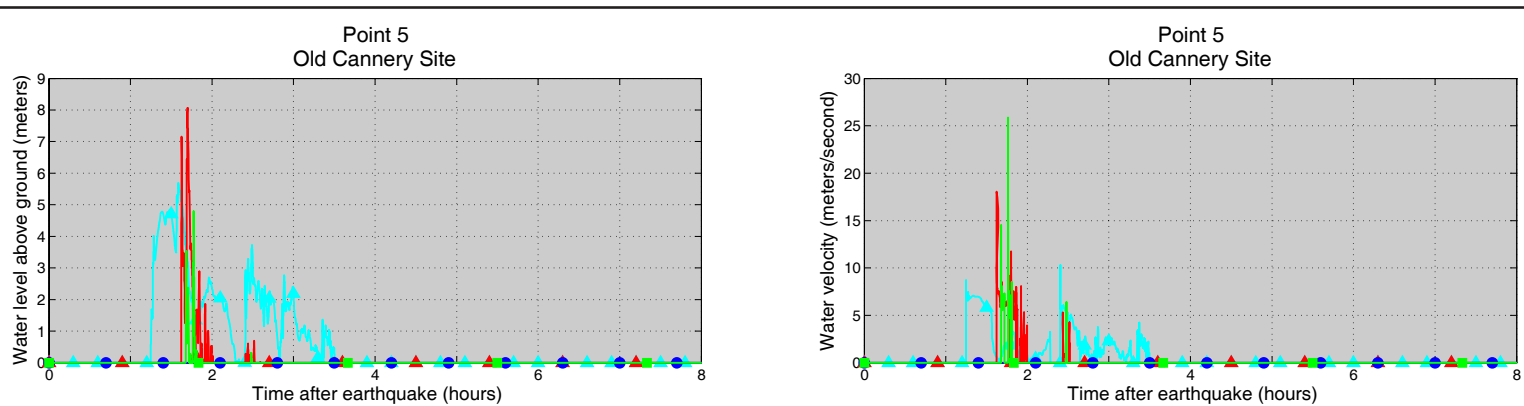

Pre-earthquake elevation $5.7 \mathrm{~m}(18.7 \mathrm{ft})$

$\triangle$ Scenario 1, Elevation $4.6 \mathrm{~m}(15.1 \mathrm{ft}) \_$Scenario 5, Elevation $5.7 \mathrm{~m}(18.7 \mathrm{ft})-$ Scenario 7, Elevation $5.2 \mathrm{~m}(17.2 \mathrm{ft})-$ Scenario 9 , Elevation $5.7 \mathrm{~m}(18.7 \mathrm{ft})$
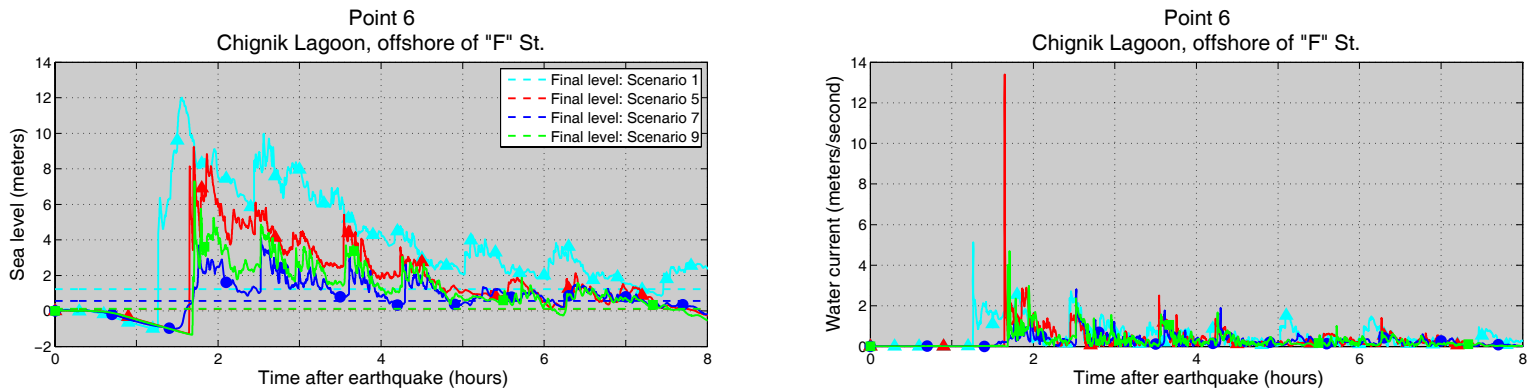

Pre-earthquake depth $1.6 \mathrm{~m}(5.2 \mathrm{ft})$

$\triangle$ Scenario 1, Depth $2.8 \mathrm{~m}(9.2 \mathrm{ft}) \backsim$ Scenario 5, Depth $1.7 \mathrm{~m}(5.6 \mathrm{ft})-$ Scenario 7, Depth $2.2 \mathrm{~m}(7.1 \mathrm{ft})-$ Scenario 9 , Depth $1.7 \mathrm{~m}(5.6 \mathrm{ft})$

Point 7

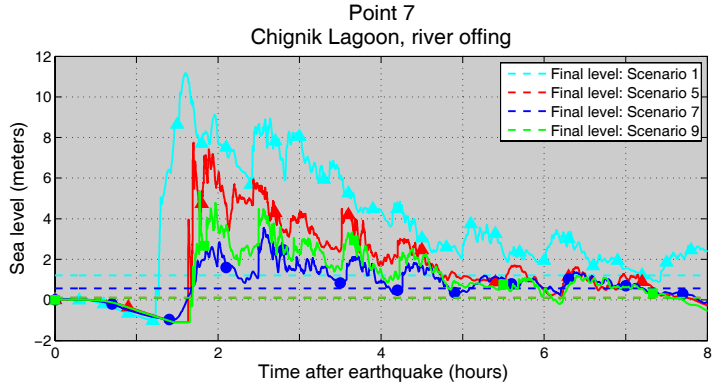

Pre-earthquake depth $1.1 \mathrm{~m}(3.6 \mathrm{ft})$

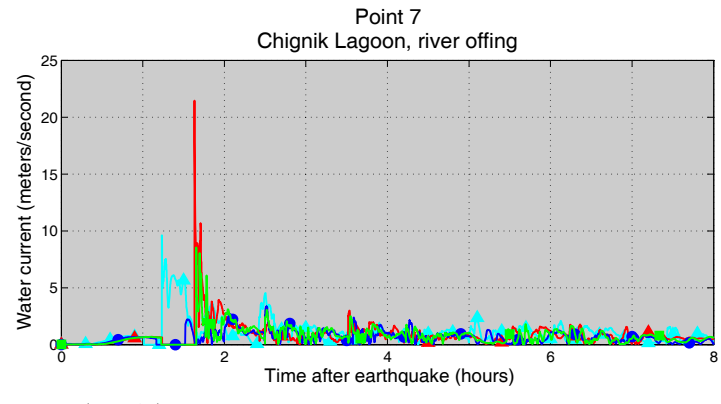

$\triangle$ Scenario 1, Depth $2.3 \mathrm{~m}(7.6 \mathrm{ft}) \_$Scenario 5, Depth $1.2 \mathrm{~m}(3.9 \mathrm{ft}) \bullet-$ Scenario 7, Depth $1.7 \mathrm{~m}(5.5 \mathrm{ft})-$ Scenario 9 , Depth $1.2 \mathrm{~m}(4.0 \mathrm{ft})$

Point 8

Chignik Lagoon, offshore of Frank St.

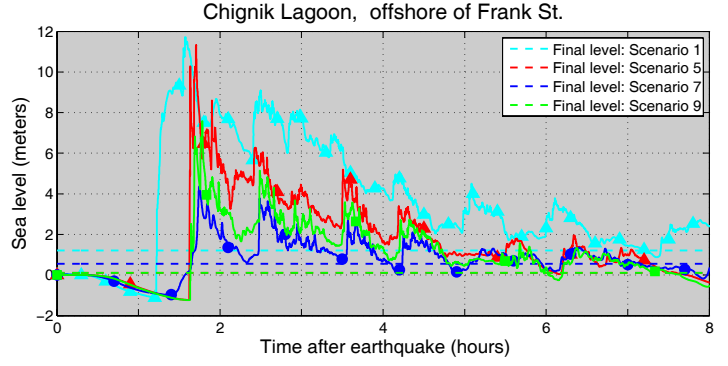

Point 8

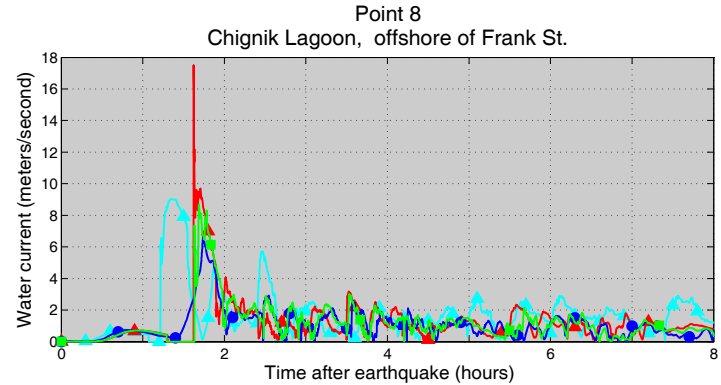

Pre-earthquake depth $1.3 \mathrm{~m}(4.3 \mathrm{ft})$

- Scenario 1, Depth $2.5 \mathrm{~m}(8.2 \mathrm{ft})-$ Scenario 5, Depth $1.4 \mathrm{~m}(4.6 \mathrm{ft})-$ Scenario 7, Depth $1.9 \mathrm{~m}(6.1 \mathrm{ft})-$ Scenario 9, Depth $1.4 \mathrm{~m}(4.6 \mathrm{ft})$

Appendix B-2, continued. Time series of water level (left) and velocity (right) at selected locations in Chignik Lagoon for scenarios 1, 5, 7, and 9. The pre-earthquake elevation/depth with respect to the MHHW is stated for each location. The post-earthquake elevation/depth corresponding to the MHHW datum is also listed for each scenario. For offshore locations, to show the height of an arriving tsunami, the vertical datum is such that zero corresponds to the pre-earthquake sea level. The dashed lines show the water level after the tsunami. 

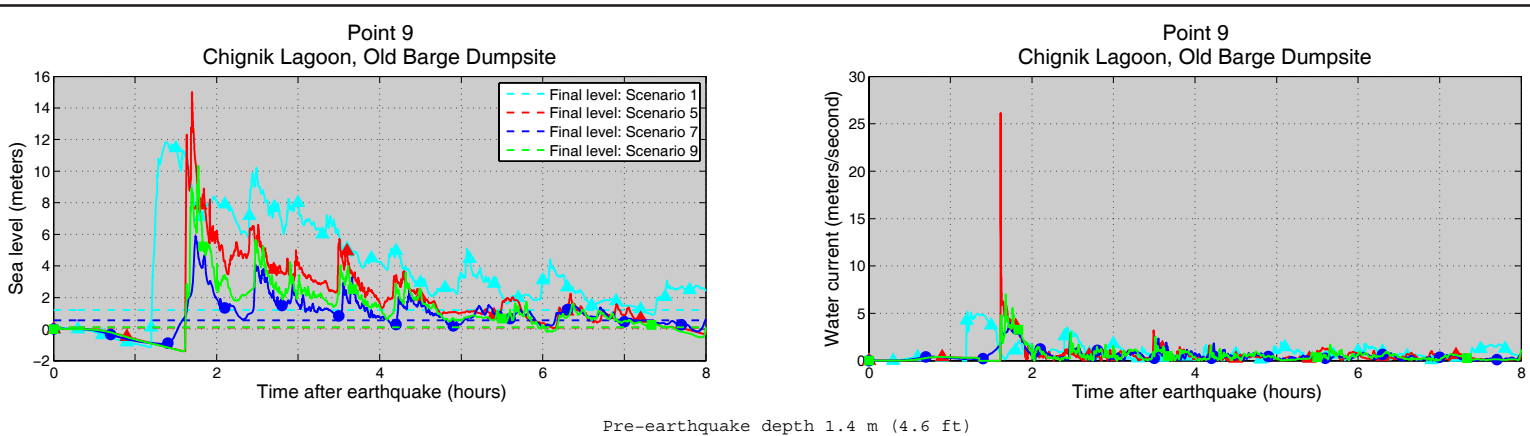

$\triangle$ Scenario 1, Depth $2.6 \mathrm{~m}(8.6 \mathrm{ft}) \backsim$ Scenario 5, Depth $1.5 \mathrm{~m}(4.9 \mathrm{ft})-$ Scenario 7, Depth $2.0 \mathrm{~m}(6.4 \mathrm{ft})-$ Scenario 9 , Depth $1.5 \mathrm{~m}(5.0 \mathrm{ft})$
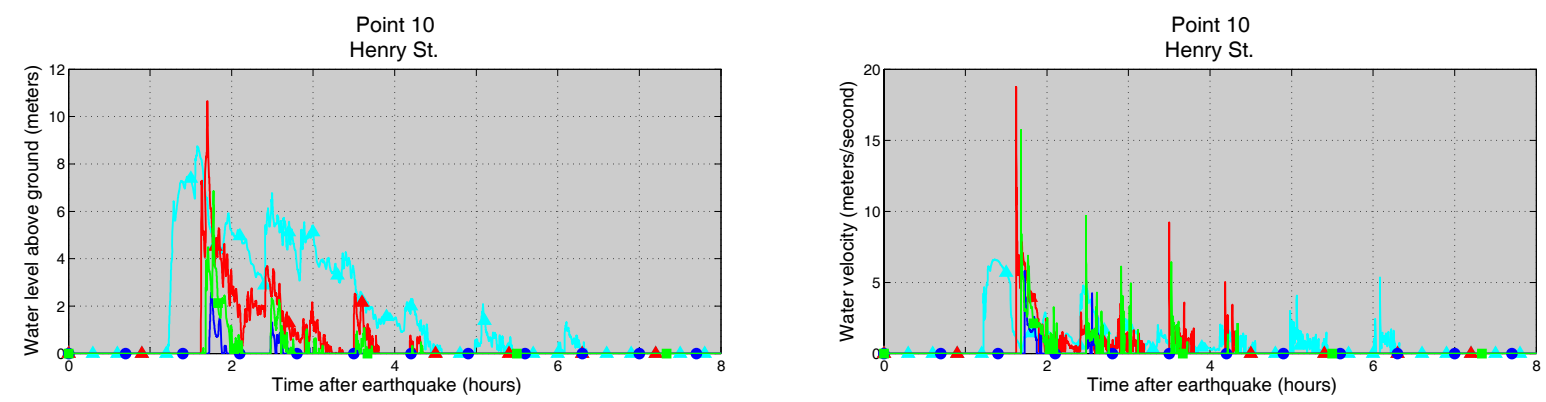

Pre-earthquake elevation $2.7 \mathrm{~m}(8.7 \mathrm{ft})$

$\triangle$ Scenario 1, Elevation $1.6 \mathrm{~m}(5.1 \mathrm{ft})-$ Scenario 5 , Elevation $2.7 \mathrm{~m}(8.8 \mathrm{ft})-$ Scenario 7 , Elevation $2.2 \mathrm{~m}(7.3 \mathrm{ft})-$ - Scenario 9 , Elevation $2.7 \mathrm{~m}(8.7 \mathrm{ft})$
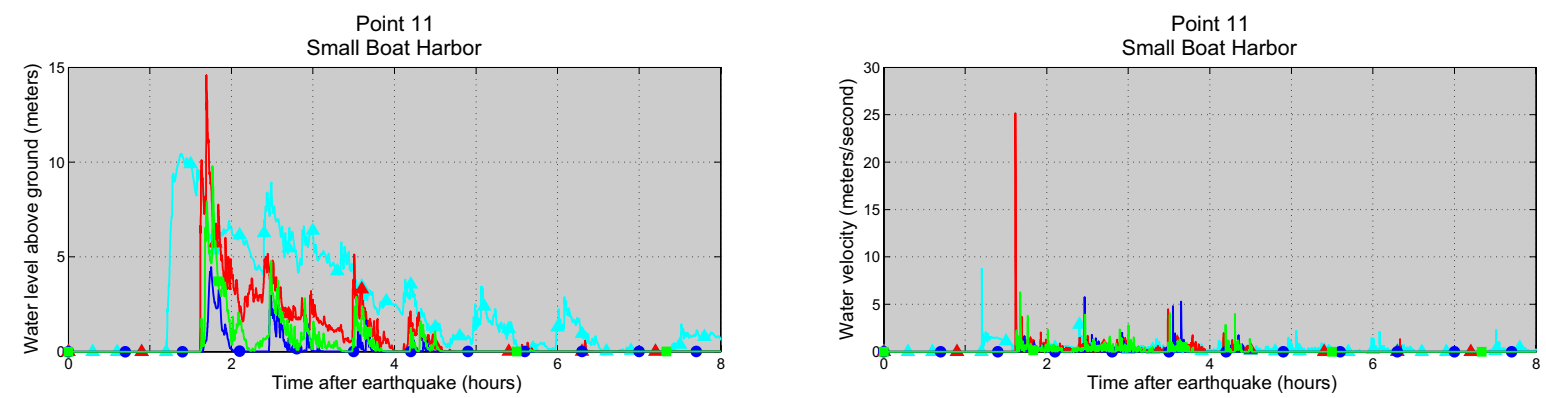

Pre-earthquake elevation $1.7 \mathrm{~m}(5.5 \mathrm{ft})$

$\triangle$ Scenario 1, Elevation $0.6 \mathrm{~m}(1.9 \mathrm{ft}) \_$Scenario 5 , Elevation $1.7 \mathrm{~m}(5.6 \mathrm{ft})-$ Scenario 7 , Elevation $1.2 \mathrm{~m}(4.0 \mathrm{ft})-$ Scenario 9 , Elevation $1.7 \mathrm{~m}(5.5 \mathrm{ft})$
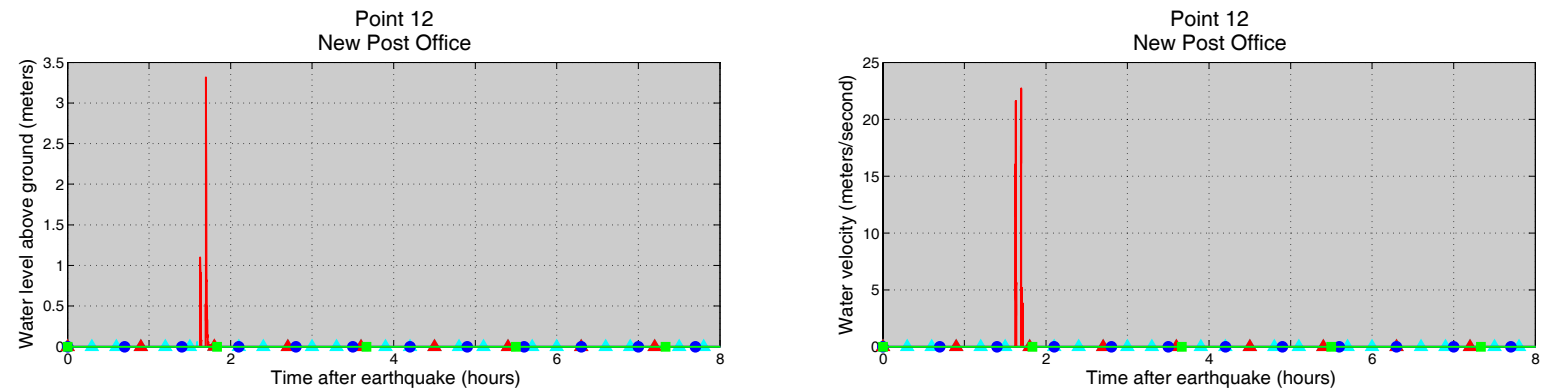

Pre-earthquake elevation $11.7 \mathrm{~m}(38.3 \mathrm{ft})$

- Scenario 1, Elevation $10.6 \mathrm{~m}(34.7 \mathrm{ft})-$ Scenario 5, Elevation $11.7 \mathrm{~m}(38.3 \mathrm{ft})-$ Scenario 7 , Elevation $11.2 \mathrm{~m}(36.8 \mathrm{ft})-$ Scenario 9 , Elevation $11.7 \mathrm{~m}(38.3 \mathrm{ft})$

Appendix B-2, continued. Time series of water level (left) and velocity (right) at selected locations in Chignik Lagoon for scenarios 1, 5, 7, and 9. The pre-earthquake elevation/depth with respect to the MHHW is stated for each location. The post-earthquake elevation/depth corresponding to the MHHW datum is also listed for each scenario. For offshore locations, to show the height of an arriving tsunami, the vertical datum is such that zero corresponds to the pre-earthquake sea level. The dashed lines show the water level after the tsunami. 

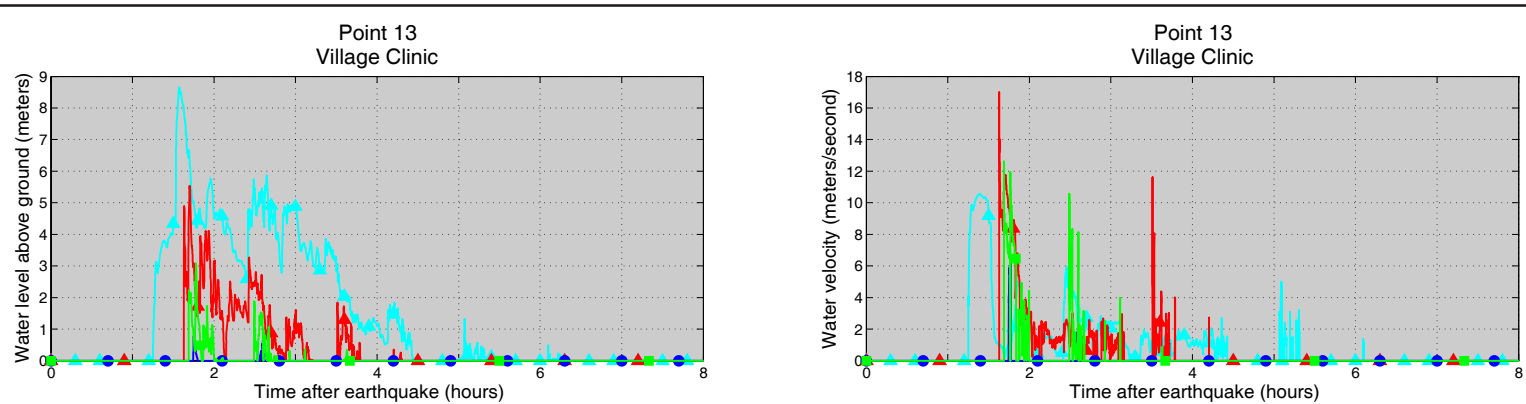

Pre-earthquake elevation $3.0 \mathrm{~m}(9.7 \mathrm{ft})$

$\triangle$ Scenario 1, Elevation $1.9 \mathrm{~m}(6.1 \mathrm{ft}) \_$Scenario 5 , Elevation $3.0 \mathrm{~m}(9.7 \mathrm{ft}) \longrightarrow$ Scenario 7, Elevation $2.5 \mathrm{~m}(8.2 \mathrm{ft})-$ - Scenario 9, Elevation $3.0 \mathrm{~m}(9.7 \mathrm{ft})$
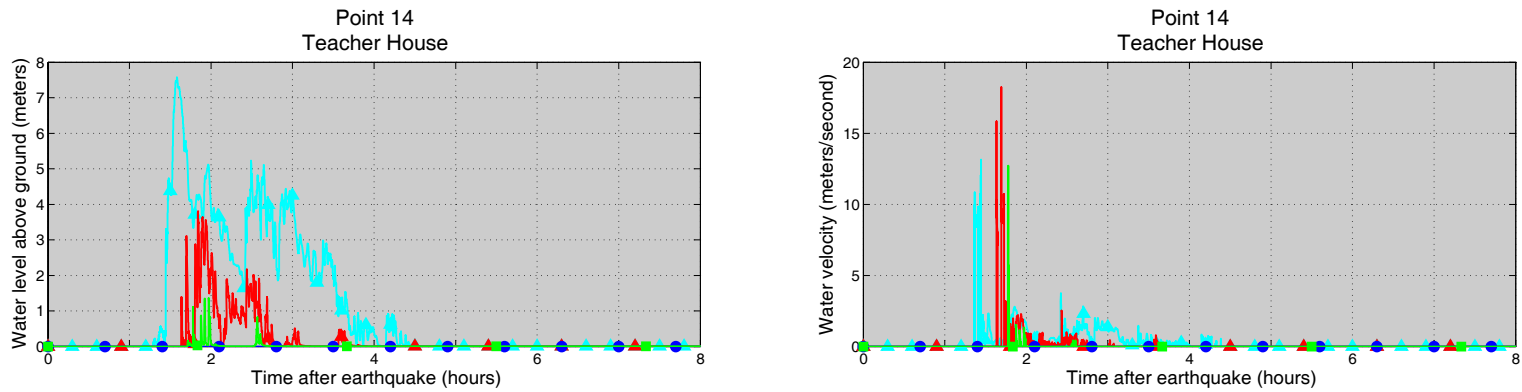

Pre-earthquake elevation $3.9 \mathrm{~m}(12.7 \mathrm{ft})$

$\triangle$ Scenario 1, Elevation $2.8 \mathrm{~m}(9.1 \mathrm{ft})-$ Scenario 5 , Elevation $3.9 \mathrm{~m}(12.8 \mathrm{ft}) \longrightarrow$ - Scenario 7, Elevation $3.4 \mathrm{~m}(11.3 \mathrm{ft})-$ Scenario 9 , Elevation $3.9 \mathrm{~m}(12.7 \mathrm{ft})$
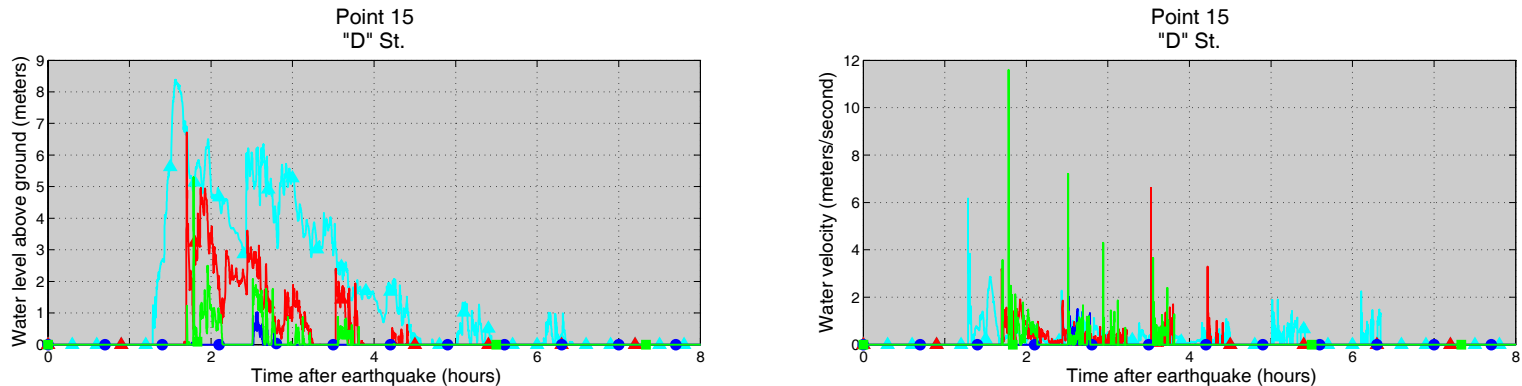

Pre-earthquake elevation $2.7 \mathrm{~m}(9.0 \mathrm{ft})$

Scenario 1, Elevation $1.6 \mathrm{~m}(5.3 \mathrm{ft}) \_$Scenario 5, Elevation $2.7 \mathrm{~m}(9.0 \mathrm{ft})-$ Scenario 7, Elevation $2.3 \mathrm{~m}(7.5 \mathrm{ft})-$ Scenario 9 , Elevation $2.7 \mathrm{~m}(9.0 \mathrm{ft})$
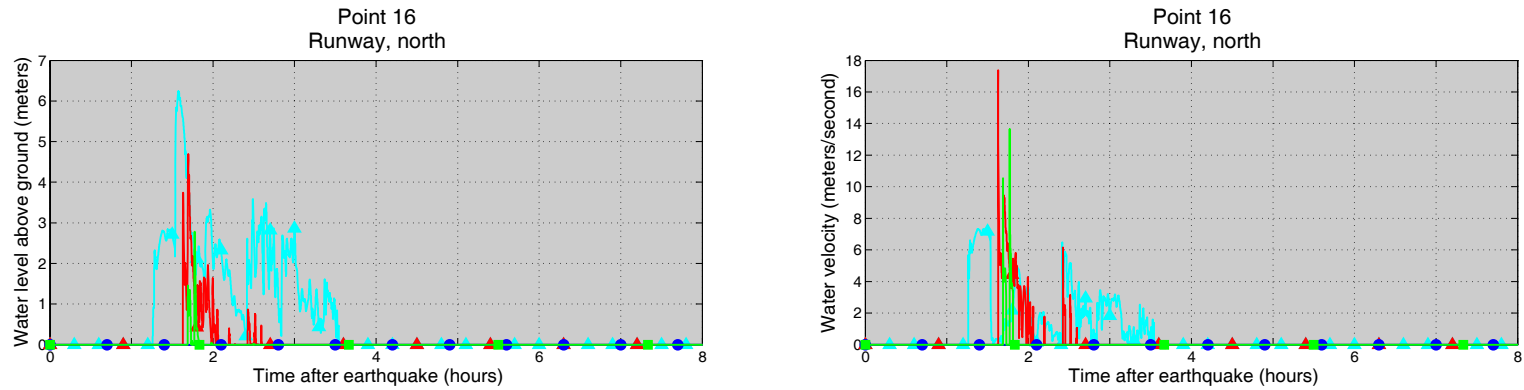

Pre-earthquake elevation $5.3 \mathrm{~m}(17.3 \mathrm{ft})$

A- Scenario 1, Elevation $4.2 \mathrm{~m}(13.7 \mathrm{ft})-$ Scenario 5 , Elevation $5.3 \mathrm{~m}(17.3 \mathrm{ftt}-\bullet$ Scenario 7, Elevation $4.8 \mathrm{~m}(15.8 \mathrm{ft})-\mathrm{m}-$ Scenario 9 , Elevation $5.3 \mathrm{~m}(17.3 \mathrm{ft})$

Appendix B-2, continued. Time series of water level (left) and velocity (right) at selected locations in Chignik Lagoon for scenarios 1, 5, 7, and 9. The pre-earthquake elevation/depth with respect to the MHHW is stated for each location. The post-earthquake elevation/depth corresponding to the MHHW datum is also listed for each scenario. For offshore locations, to show the height of an arriving tsunami, the vertical datum is such that zero corresponds to the pre-earthquake sea level. The dashed lines show the water level after the tsunami. 


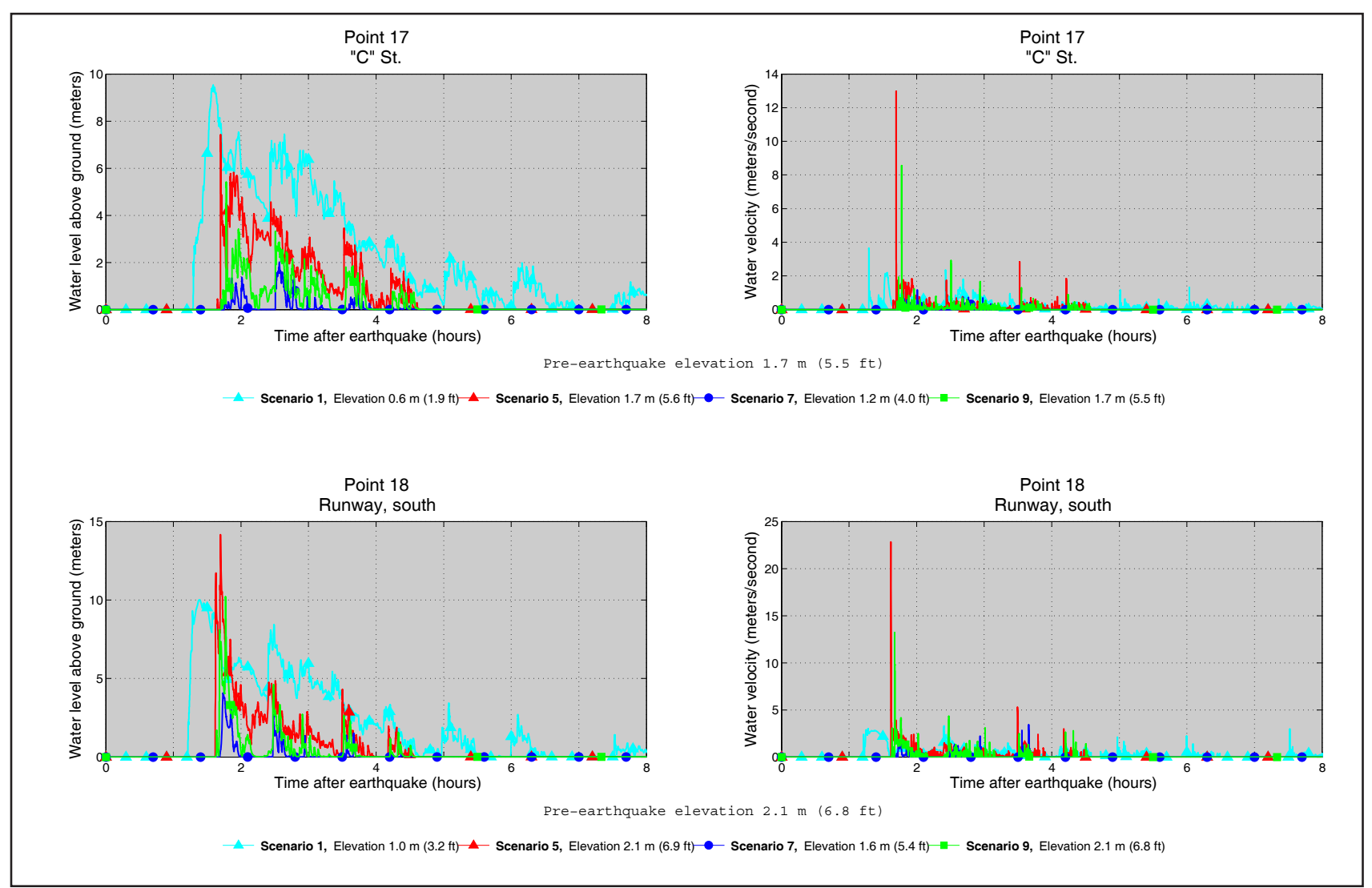

Appendix B-2, continued. Time series of water level (left) and velocity (right) at selected locations in Chignik Lagoon for scenarios 1, 5, 7, and 9. The pre-earthquake elevation/depth with respect to the MHHW is stated for each location. The post-earthquake elevation/depth corresponding to the MHHW datum is also listed for each scenario. For offshore locations, to show the height of an arriving tsunami, the vertical datum is such that zero corresponds to the pre-earthquake sea level. The dashed lines show the water level after the tsunami. 


\begin{tabular}{|c|c|c|c|c|c|c|c|c|c|c|c|c|c|c|c|c|c|c|c|}
\hline$\infty$ & $\Xi$ & $\vec{a}$ & $\vec{u}$ & $\not$ & $\bar{\omega}$ & $\bar{N}$ & $=$ & 0 & 6 & $\infty$ & $\checkmark$ & $a$ & ur & $A$ & $\omega$ & $N$ & - & & $\#$ \\
\hline 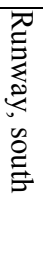 & $\begin{array}{l}\mathscr{2} \\
\mathscr{\sigma}\end{array}$ & 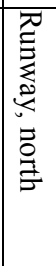 & $\begin{array}{l}\vec{\sigma} \\
\mathscr{\sigma}\end{array}$ & 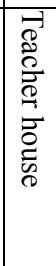 & 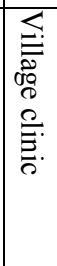 & 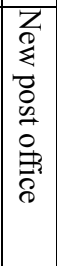 & 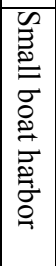 & 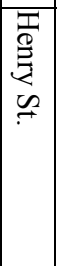 & 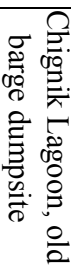 & 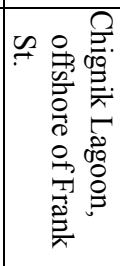 & 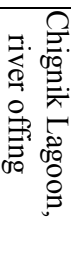 & 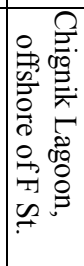 & 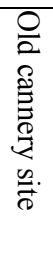 & $\begin{array}{l}\text { W } \\
0 \\
0 \\
0 \\
0 \\
0 \\
0 \\
0 \\
0 \\
0 \\
0\end{array}$ & 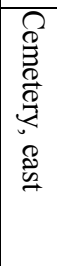 & 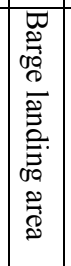 & 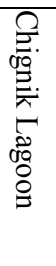 & & $\begin{array}{l}\overline{\tilde{\sigma}} \\
\stackrel{\tilde{D}}{0}\end{array}$ \\
\hline$\sim$ & $\Omega$ & $n$ & $\backsim$ & $n$ & $n$ & in & 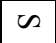 & es & 0 & 0 & 0 & 0 & $\sim s$ & $n$ & is & $\infty$ & 0 & & $1-0$ \\
\hline 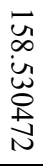 & 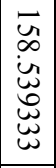 & $\begin{array}{l}\vec{\omega} \\
\infty \\
\dot{\omega} \\
\dot{\omega} \\
\vec{u} \\
\ddot{\delta}\end{array}$ & 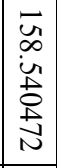 & 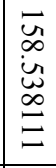 & 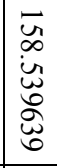 & 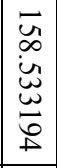 & $\begin{array}{l}\vec{\omega} \\
\infty \\
i \\
i \\
\infty \\
\infty \\
\infty \\
\infty \\
\infty\end{array}$ & 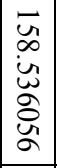 & 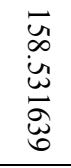 & \begin{tabular}{l}
$\vec{u}$ \\
$\infty$ \\
$i n$ \\
\multirow{1}{*}{} \\
0 \\
$a$
\end{tabular} & 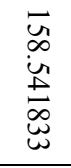 & 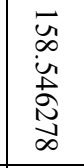 & $\begin{array}{l}\vec{\omega} \\
\infty \\
\dot{w} \\
w \\
\omega \\
\sigma\end{array}$ & 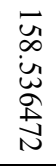 & 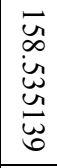 & 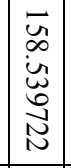 & 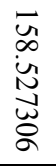 & & 葛 \\
\hline 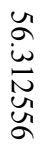 & 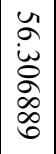 & 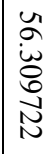 & 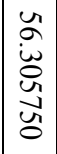 & 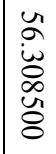 & $\begin{array}{l}u_{2} \\
\dot{\hat{\omega}} \\
0 \\
0 \\
0 \\
0 \\
0\end{array}$ & 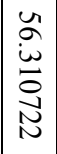 & 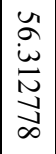 & 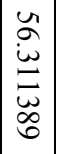 & 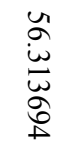 & 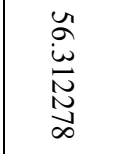 & 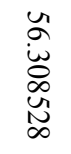 & 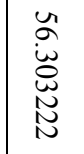 & 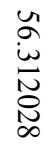 & $\begin{array}{l}\text { Uू } \\
\dot{\omega} \\
\dot{\infty} \\
\stackrel{+}{+}\end{array}$ & 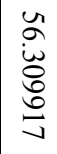 & 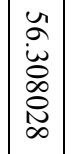 & 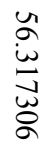 & & Z \\
\hline : & $\dot{b}$ & w & $\stackrel{\ominus}{v}$ & $\bar{\sigma}$ & $\dot{0}$ & $\ddot{v} \cdot$ & $\dot{b}$ & $\stackrel{\ominus}{v}$ & 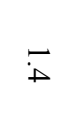 & $i$ & 5 & $\dot{a}$ & $\stackrel{\omega}{v}$ & $\overrightarrow{6}$ & $\stackrel{\infty}{i}$ & i & i & & 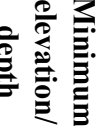 \\
\hline ○ & $\begin{array}{l}0 \\
\text { in }\end{array}$ & ì & $\begin{array}{l}\infty \\
\dot{+}\end{array}$ & $\vec{a}$ & 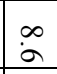 & $\stackrel{\circ}{-}$ & $\underset{\perp}{\circ}$ & $\stackrel{\infty}{\infty}$ & $\underset{\infty}{\vec{\infty}}$ & $\Xi$ & $\overline{\tilde{N}}$ & $\stackrel{N}{0}$ & $\ddot{v}$ & 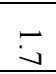 & 5 & $\stackrel{0}{i}$ & $\overline{6}$ & - & \\
\hline $\begin{array}{l}0 \\
\text { in }\end{array}$ & $\stackrel{\infty}{0}$ & $\dot{a}$ & 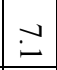 & 0 & 6 & $\stackrel{0}{0}$ & $\begin{array}{l}0 \\
0\end{array}$ & $\dot{0}$ & 巨 & $\stackrel{0}{0}$ & $\begin{array}{l}0 \\
\perp\end{array}$ & $\vec{\ominus}$ & $\vec{i}$ & $\dot{0}$ & $\dot{0}$ & $\stackrel{.}{+}$ & 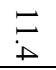 & N & \\
\hline 0 & $\overrightarrow{-}$ & $\stackrel{\imath}{\imath}$ & $\begin{array}{l}\infty \\
\infty \\
\infty\end{array}$ & $\stackrel{\infty}{-}$ & $\because$ & $\circ$ & $\vec{\omega}$ & i & $\varpi_{\infty}$ & $\Xi$ & $\overline{6}$ & $\underset{\sim}{\vec{D}}$ & $\stackrel{2}{2}$ & i & ă & $\stackrel{0}{\sim}$ & $\varpi_{\infty}$ & $\omega$ & \\
\hline 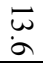 & $\grave{a}$ & 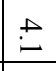 & $\ddot{o}$ & $\stackrel{w}{i}$ & $\stackrel{+}{\infty}$ & $\stackrel{N}{0}$ & 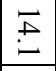 & i & $\begin{array}{c}\omega \\
\infty \\
\infty\end{array}$ & i & $i$ & $\infty$ & $\stackrel{\sim}{ }$ & à & No & $\overrightarrow{i_{i}}$ & $\overrightarrow{\tilde{\sigma}}$ & $\perp$ & \\
\hline i & $\stackrel{\sim}{\triangle}$ & $\stackrel{+}{\sim}$ & $\ddot{v}$ & $\underset{\infty}{\omega}$ & $\ddot{u}$ & $\stackrel{\omega}{\omega}$ & $\vec{p}$ & $\stackrel{\vec{v}}{\ominus}$ & $\vec{u}$ & 二 & $\vec{v}$ & $\stackrel{0}{i}$ & $\infty$ & $\bar{i}$ & No & $\ddot{a}$ & $\underset{\infty}{\vec{\omega}}$ & er & \\
\hline $\begin{array}{l}w_{n} \\
u_{1}\end{array}$ & ì & w & $\ddot{0}$ & $\ddot{\omega}$ & $\vec{b}$ & $\vec{\perp}$ & $\begin{array}{l}\vec{\omega} \\
\sigma\end{array}$ & $\stackrel{0}{\sim}$ & $\vec{P}$ & $\overline{0}$ & $\dot{a}$ & $\dot{\sigma}$ & in & is & ă & $\overrightarrow{i_{2}}$ & $\vec{N}$ & $a$ & \\
\hline$\stackrel{+}{t}$ & $\begin{array}{r}n \\
0\end{array}$ & 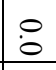 & $\dot{0}$ & $\therefore$ & $\stackrel{\circ}{\infty}$ & $\stackrel{8}{0}$ & $\overrightarrow{i n}$ & $\stackrel{n}{a}$ & $\ddot{6}$ & $\stackrel{\vec{D}}{\vec{A}}$ & $\tilde{u}_{1}$ & $\stackrel{t}{i}$ & $\because$ & $\stackrel{\circ}{\circ}$ & $\dot{0}$ & $\vec{\perp}$ & in & $\checkmark$ & \\
\hline $\begin{array}{l}\infty \\
\dot{a}\end{array}$ & $\begin{array}{l}0 \\
i\end{array}$ & $\vec{a}$ & $\stackrel{\infty}{\perp}$ & in & 6 & $\stackrel{0}{0}$ & i & 6 & $\underset{i}{\vec{N}}$ & 0 & $i$ & & $\stackrel{\bullet}{ }$ & $=$ & $\stackrel{0}{0}$ & $\begin{array}{l}\infty \\
i \\
\sim\end{array}$ & $\overrightarrow{{ }_{0}}$ & $\infty$ & \\
\hline i & $\begin{array}{l}u \\
\dot{A}\end{array}$ & $\begin{array}{l}N \\
\infty \\
\infty\end{array}$ & $u$ & $\stackrel{\vec{A}}{+}$ & $\stackrel{w}{-}$ & $\stackrel{0}{0}$ & $\begin{array}{r}0 \\
\infty \\
\infty\end{array}$ & 6 & $\vec{\omega}$ & $\checkmark$ & $\ddot{a}$ & $i$ & $\underset{\infty}{\infty}$ & $\because$ & $\stackrel{0}{0}$ & $\begin{array}{c}\omega \\
i \\
\omega\end{array}$ & i & 0 & \\
\hline$\stackrel{0}{0}$ & $\stackrel{0}{0}$ & $\stackrel{0}{0}$ & $\stackrel{0}{0}$ & $\stackrel{0}{0}$ & $\stackrel{0}{0}$ & $\stackrel{\circ}{0}$ & i & $\stackrel{\circ}{0}$ & $\stackrel{N}{\circ}$ & $\dot{a}$ & $\bar{i}^{\prime}$ & & $\stackrel{0}{0}$ & $\stackrel{0}{0}$ & 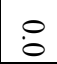 & $\because$ & $\overline{6}$ & $\overline{0}$ & \\
\hline$\dot{0}$ & $\because$ & $\dot{0}$ & $\stackrel{\circ}{\circ}$ & $\because$ & $\dot{0}$ & $\dot{0}$ & $\because$ & $\stackrel{0}{0}$ & $\dot{0}$ & 6 & $v$ & & $\dot{0}$ & $\stackrel{0}{0}$ & 잉 & $\stackrel{\circ}{0}$ & i & $=$ & \\
\hline$\ddot{\omega}$ & $\begin{array}{l}\omega \\
\dot{a}\end{array}$ & $\dot{\omega}$ & ì & $\overrightarrow{.}$ & $\vec{D}_{1}$ & $\stackrel{\circ}{0}$ & $\begin{array}{l}\infty \\
\infty \\
\infty\end{array}$ & $\hat{\alpha}$ & $\tilde{i}$ & & 2 & $u$ & $\underset{i}{i}$ & $\infty$ & $\ddot{i}$ & $\vec{i}$ & $\ddot{a}$ & - & \\
\hline$\stackrel{+}{0}$ & $\omega$ & $\stackrel{\vec{v}}{\bullet}$ & $\hat{i}$ & $\vec{i}$ & is & $\because$ & $\tilde{\omega}_{n}$ & iे & $\overrightarrow{6}$ & $\infty$ & $\infty$ & $A$ & $\Xi$ & $\because$ & $\stackrel{0}{0}$ & $\Xi$ & $\ddot{u n}$ & N & \\
\hline$\ddot{\omega}$ & $\tilde{u}$ & $\stackrel{0}{2}$ & $\begin{array}{l}n \\
\infty\end{array}$ & $\vec{i}$ & $\begin{array}{l}\vec{D} \\
+\end{array}$ & $\stackrel{\circ}{0}$ & i & in & $\ddot{A}$ & $\infty$ & 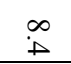 & un & 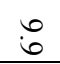 & $\overrightarrow{0}$ & $\stackrel{N}{\infty}$ & $\stackrel{\infty}{\dot{y}}$ & $\stackrel{u}{u}$ & $\omega$ & \\
\hline$\stackrel{N}{ \pm}$ & $\stackrel{\sim}{\sim}$ & $\begin{array}{l}\overrightarrow{0} \\
i \\
\end{array}$ & $\infty$ & ă & $\begin{array}{l}N \\
\\
0\end{array}$ & $\stackrel{N}{\stackrel{N}{v}}$ & $\begin{array}{l}w_{0} \\
\dot{u}\end{array}$ & $\begin{array}{l}\overrightarrow{0} \\
0\end{array}$ & $\stackrel{N}{ \pm}$ & $\exists$ & $N$ & $\overline{u_{n}}$ & $\stackrel{N}{\sim}$ & $\vec{\square}$ & $\underset{\Delta}{\vec{D}}$ & $\begin{array}{l}\mp \\
\dot{\alpha}\end{array}$ & $\infty$ & A & \\
\hline$\stackrel{N}{N}$ & $\vec{\omega}$ & $\vec{\Delta}$ & $\grave{a}$ & $\underset{\sim}{\infty}$ & $\vec{v}$ & $\stackrel{N}{N}$ & $\begin{array}{l}\tilde{N} \\
\tilde{N}\end{array}$ & $\begin{array}{l}\infty \\
\infty \\
\infty\end{array}$ & $\tilde{N}$ & $\overrightarrow{u_{1}}$ & $\stackrel{N}{\stackrel{\sim}{\perp}}$ & $\vec{\omega}$ & $\vec{\infty}$ & $\underset{\perp}{\infty}$ & $\underset{\infty}{\vec{\infty}}$ & $\begin{array}{l}\vec{u} \\
\infty\end{array}$ & $\stackrel{\infty}{\vec{\nu}}$ & er & \\
\hline$\stackrel{N}{\sim}$ & $\stackrel{\bullet}{\ominus}$ & $\begin{array}{c}\vec{n} \\
\infty \\
\end{array}$ & $i$ & $\begin{array}{l}\omega_{0} \\
0\end{array}$ & $\begin{array}{l}\overrightarrow{0} \\
\dot{a}\end{array}$ & $\underset{+}{+}$ & $\begin{array}{l}\mathbf{N} \\
a \\
\end{array}$ & $\overrightarrow{0}$ & $\begin{array}{c}N \\
\infty \\
\infty\end{array}$ & & & & $\begin{array}{c}N \\
0 \\
0\end{array}$ & $\stackrel{0}{0}$ & $\infty$ & $\begin{array}{l}\bar{N} \\
\dot{\sigma}\end{array}$ & $\vec{\infty}$ & $a$ & \\
\hline$\omega^{\omega}$ & $\stackrel{N}{0}$ & $\therefore$ & 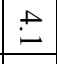 & $\stackrel{0}{0}$ & is & 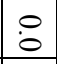 & $\ddot{\infty}$ & $\vec{N}$ & 0 & & & & $\therefore$ & $\because$ & : & $\begin{array}{l}N \\
\stackrel{N}{+}\end{array}$ & $\stackrel{\vec{i}}{i}$ & - & \\
\hline$\ddot{\omega}$ & $\begin{array}{l}w \\
\dot{b}\end{array}$ & $\begin{array}{l}\vec{w} \\
\dot{\omega}\end{array}$ & $\stackrel{+}{\sim}$ & $\begin{array}{l}n \\
\infty \\
\infty\end{array}$ & $\vec{i}$ & $\stackrel{0}{0}$ & $\begin{array}{l}\omega \\
\sigma\end{array}$ & $\ddot{\omega}$ & $\dot{a}$ & 0 & $\overrightarrow{u_{r}}$ & $a$ & $\bar{N}$ & 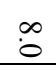 & 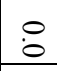 & $\vec{a}$ & $\stackrel{\vec{i}}{\mathrm{~N}}$ & $\infty$ & \\
\hline$\underset{i}{w}$ & $\begin{array}{l}\infty \\
a\end{array}$ & $\begin{array}{l}w \\
\dot{a}\end{array}$ & $\bar{a}$ & $\stackrel{\vec{v}}{v}$ & $\begin{array}{l}\bar{n} \\
\dot{a}\end{array}$ & $\ddot{0}$ & iे & $\vec{u}$ & $\ddot{0}$ & & & & $\begin{array}{l}N \\
\text { Und }\end{array}$ & $\stackrel{\circ}{0}$ & $\dot{0}$ & $\Xi$ & iे & 6 & \\
\hline$\dot{0}$ & $\stackrel{0}{0}$ & $\stackrel{\circ}{0}$ & $\dot{0}$ & $\stackrel{0}{0}$ & $\stackrel{0}{0}$ & $\stackrel{0}{0}$ & 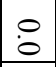 & $\dot{0}$ & $\overline{6}$ & $i$ & 0 & $\dot{\infty}_{\infty}$ & 0 & $\stackrel{0}{0}$ & 0 & $\because$ & $\overline{i_{r}}$ & $\theta$ & \\
\hline 8 & $\stackrel{0}{0}$ & $\stackrel{0}{0}$ & $\because$ & $\stackrel{\circ}{0}$ & $\because$ & $\stackrel{9}{0}$ & $\stackrel{\circ}{0}$ & $\stackrel{\circ}{0}$ & $\vec{\perp}$ & $\infty$ & 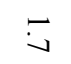 & $\doteqdot$ & $\stackrel{0}{0}$ & $\stackrel{0}{0}$ & $\stackrel{0}{0}$ & $\stackrel{9}{0}$ & $\overline{\mathrm{N}}$ & $=$ & \\
\hline
\end{tabular}

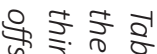
종

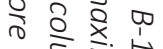

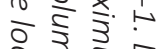

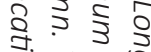

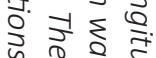
उ $\frac{1}{0} \frac{0}{0}$ ร.

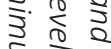
उ 워 욜 ग 원.

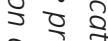

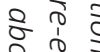
ำ 0 군 운

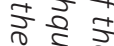
0 잉 0 ते $\frac{2}{3} \sum^{\frac{0}{2}}$ ธิ ธั

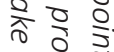
$3 \leq$. 종

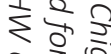

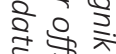

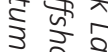
ज. 응 옹 항

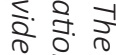
내 of

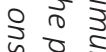

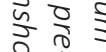
के 다워 을 色 $\frac{1}{0} \frac{1}{0}$ 용 ह

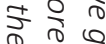
ร ธิ 공ำ ร 웡 는 가워 을 ₹ $\overline{0}$

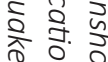
ㄴำ

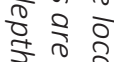

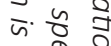

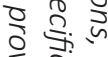
동 25 空范 